\title{
The Protection of the Right to Life at the Intersection between Reproductive Rights and Scientific Progress in the Jurisprudence of the Inter-American Court of Human Rights and the European Court of Human Rights
}

\section{La protección del derecho a la vida en la intersección entre derechos reproductivos y progreso científico en la jurisprudencia de la Corte Inter-Americana de Derechos Humanos y del Tribunal Europeo de Derechos Humanos}

\author{
Simona Fanni ${ }^{1}$ \\ Università degli studi di Cagliari (Italia)
}

Recibido: 06-08-18

Aprobado: 05-09-18

\begin{abstract}
The definition of the beginning of life and the protection of the right to life when conflicting entitlements and interests emerge are highly disputed issues worldwide, and the Inter-American Court of Human Rights (IACtHR) and the European Court of Human Rights (ECtHR) have been called to tackle these questions in their jurisprudence, especially when reproductive rights were at stake. In this respect, this paper focuses on the status of human embryo and on prenatal life and provides an assessment of the approaches that the two Courts have developed when dealing with such delicate issues as in vitro fertilization (IVF) and abortion, respectively through the pervasive scrutiny of the San José Court and its purposeful impact on the domestic sphere and
\end{abstract}

${ }^{1}$ (simona.fanni@outlook.it). PhD Candidate in Legal Sciences at the University of Cagliari (Italy). 
usually through the recognition of a wide margin of appreciation by the Strasbourg Court. In this regard, this paper provides an analysis of the Courts' most significant case law, as Artavia Murillo v. Costa Rica and 'Beatriz' cases, with reference to the IACtHR, and the ECtHR's decisions Vo v. France, Evans v. the United Kingdom, S.H. and Others v. Austria, Costa and Pavan v. Italy, Parrillo v. Italy and A, B, C v. Ireland, while considering the peculiarities of the systems of the American Convention on Human Rights and the European Convention on Human Rights and the role of the Convention on Human Rights and Biomedicine and its Protocols in Strasbourg jurisprudence. Moving from this assessment, this paper aims to suggest possible solutions to improve the results achieved by the two Courts, also through judicial cross-fertilization and through reference to the relevant international instruments according to Article 31(3)(c) of the Vienna Convention on the Law of the Treaties, for example the right to enjoy the benefits of scientific progress enshrined in the International Covenant on Economic, Social and Cultural Rights.

Key-words: Embryo, prenatal life, reproductive rights, abortion, European Court of Human Rights, Inter-American Court of Human Rights, right to enjoy the benefits of scientific progress.

\section{Resumen}

La definición del comienzo de la vida y la protección del derecho a la vida cuando surgen derechos e intereses contradictorios son cuestiones altamente controvertidas en todo el mundo, y la Corte Interamericana de Derechos Humanos (CIDH) y el Tribunal Europeo de Derechos Humanos (TEDH) han abordado estas cuestiones en su jurisprudencia, especialmente cuando los derechos reproductivos estaban en juego. En este sentido, este trabajo se centra en el estatus del embrión humano y en la vida prenatal y evalúa los enfoques que los dos tribunales han desarrollado cuando se trata de cuestiones tan delicadas como la fertilización in vitro (FIV) y el aborto, tanto el de la Corte de San José, con su severo escrutinio y su poderoso impacto sobre la esfera nacional interna, cuanto el del Tribunal de Estrasburgo, basado por lo general en un amplio margen de apreciación. En este sentido, el presente artículo aporta un análisis de los casos que sentaron jurisprudencia, como Artavia Murillo contra Costa Rica y los casos 'Beatriz', en relación con la CIDH, y en el marco del TEDH, en Vo contra Francia, Evans contra el Reino Unido, S. H. y Otros contra Austria, Costa y Pavan contra Italia, Parrillo contra Italia y A, B, C contra Irlanda, teniendo al tiempo en consideración las particularidades de los sistemas de la Convención Americana sobre Derechos Humanos y del Convenio Europeo sobre Derechos Humanos, así como el papel de la Convención sobre Derechos Humanos y Biomedicina y sus Protocolos en la jurisprudencia de Estrasburgo. Partiendo de la citada evaluación, el presente 
artículo aspira a sugerir soluciones posibles que mejoren los resultados alcanzados por ambos Tribunales, sea por medio de la influencia recíproca judicial o a través de la referencia a instrumentos internacionales relevantes según el artículo 31(3) (c) de la Convención de Viena sobre el Derecho de los Tratados, como, por ejemplo, el derecho a gozar de los beneficios del progreso científico, consagrado en el Pacto Internacional sobre Derechos Económicos, Sociales y Culturales.

Palabras-clave: embrión, vida prenatal, derechos reproductivos, aborto, Tribunal Europeo de Derechos Humanos, Corte Interamericana de Derechos Humanos, derecho al goce de los beneficios del progreso científico.

\section{Introduction}

"We made history".

These are the words by which Irish women welcomed the results of the referendum that took place last May 2018 on the removal of the prohibition of abortion from the Irish legal order.

What constitutes a revolution for Ireland after the ban on abortion was enshrined in the Constitution thirty-five years ago, also represents a strong indicator of the importance that the debate on the beginning of life and reproductive rights has assumed worldwide, also propelled by the relentless scientific progress. The debate on these questions has assumed unprecedented proportions around the world, and Europe and Latin America appear to be in the front line, although their historical and legal background is often quite different. The time for reform seems to have eventually come: Ireland and Poland, in Europe, and Argentina and Chile, in Latin America, offer paradigmatic examples of how change is simmering globally. However, the sensitive nature of the issues at stake cannot be overlooked and common legal standards are to be sought in order to accommodate the legal, ethical and cultural pluralism that characterizes them. In this respect, a bioethical and human rights-based approach seems to provide the adequate forum for a constructive discussion and for ensuring appropriate protection for the often conflicting rights at stake. Indeed, it is not unusual that the safeguarding of prenatal life clashes with various entitlements of the mother, ranging from life, physical integrity, health, self-determination and private life and, from a wider perspective, also the right to enjoy the benefits of scientific progress and its applications. In fact, the gap can be hard to bridge when some of the reproductive horizons offered by scientific progress, of which in vitro fertilization and embryo manipulation are prime examples, are taken into account.

This study focuses on how the judicial bodies of two major regional human rights systems, namely the European Court of Human Rights (ECtHR) within 
the Council of Europe (COE) and the Inter-American Court of Human Rights (IACtHR) within the Organization of the American States (OAS) have tackled the definition of the beginning of life and its interplay with reproductive rights offering, through their case law, an important and innovative interpretation of the European Convention on Human Rights $(\mathrm{ECHR})^{2}$ and the American Convention on Human Rights (ACHR). ${ }^{3}$

This paper primarily analyses the scientific framework concerning the beginning of life and the definition of the different stages of the development of the human embryo, from conception and implantation to the evolution into the foetus, along with the evolution of the philosophical thought on these issues. A reconstruction of the legal evolution of the status of embryo and of reproductive rights and their conceptualization as "non-independent human rights", also through analysis of some interesting national experiences, brings the reflection to its international dimension. The scientific complexity of the question and the difficulty to deal with the pluralism of views worldwide is reflected by the landscape of international law, whose approach is assessed through analysis of the most significant human rights generalist and thematic treaties, ranging from the International Covenant on Civil and Political Rights (ICCPR) ${ }^{4}$ to the Convention on the Rights of the Child (CRC) ${ }^{5}$ and the Convention on the Elimination of All Forms of Discrimination against Women (CEDAW). ${ }^{6}$

Under this premise, the focus is set on the respective case law of the ECtHR and of the IACtHR through analysis of their significant decisions concerning the status of human embryo and prenatal life when human rights issues related to in vitro fertilization (IVF) and abortion were raised before them. Specifically, this study addresses the approach adopted by the Strasbourg Court in the judgments Vo v. France, Evans v. the United Kingdom, S.H. and Others v. Austria, Costa and Pavan v. Italy, Parrillo v. Italy and $A, B, C$ v. Ireland, and by the Court of San José in the cases of Artavia Murillo v. Costa

\footnotetext{
${ }^{2}$ Council of Europe, European Convention for the Protection of Human Rights and Fundamental Freedoms, as amended by Protocols Nos. 11 and 14 (adopted 4 November 1950, entered into force 3 September 1953) ETS 5availbale at https://www.echr.coe.int/Documents/Convention_ENG.pdf last accessed 4 June 2018.

${ }^{3}$ Organization of American States (OAS), American Convention on Human Rights, "Pact of San Jose", Costa Rica (adopted 22 November 1969, entered into force 18 July 1978) OAS, Treaty Series, No. 36, available at https://www.cidh.oas.org/basicos/english/basic3.american\%20convention.htm last accessed 4 June 2018.

${ }^{4}$ UN General Assembly, International Covenant on Civil and Political Rights (adopted 16 December 1966, entered into force 23 March 1976) United Nations, Treaty Series, vol. 999, p. 171, available at https://www.ohchr.org/en/professionalinterest/pages/ccpr.aspx last accessed 4 June 2018.

5 UN General Assembly, Convention on the Rights of the Child (adopted 20 November 1989, entered into force 2 September 1990) United Nations, Treaty Series, vol. 1577, p. 3, available at https://www.ohchr.org/en/professionalinterest/pages/crc.aspx last accessed 4 June 2018.

${ }^{6}$ UN General Assembly, Convention on the Elimination of All Forms of Discrimination Against Women (adopted 18 December 1979, entered into force 3 September 1981) United Nations, Treaty Series, vol. 1249, available at http://www.un.org/womenwatch/daw/cedaw/cedaw.htm last accessed 4 June 2018.
} 
Rica and 'Beatriz'. Again, the judgment issued by the IACtHR in the case of the Comunidad Indígena Xákmok Kásek c. Paraguay is considered as a missed opportunity to provide some important reading of the scope of the right to life with respect to the nasciturus, and some better understanding of the pluralism within the OAS and the possibility to reconcile the different views is sought by expanding on the case of Baby Boy v. the United States, when the InterAmerican Commission on Human Rights faced with the challenges related with prenatal life for the first time in the Inter-American system in 1981. Some explanations are sought for the different approach of the two Courts and the distinct results achieved through critical, comparative analysis: in this regard, whilst the ECtHR seems to valorise pluralism through a careful application of the margin of appreciation, the IACtHR does not apply this doctrine in the Artavia Murillo judgment, and offers some interesting examples of an evolutive reading of States' duties under the ACHR with regard to reproductive rights, in line with its wide use of international binding and non-binding reference instruments pursuant to Article 31 of the Vienna Convention on the Law of the Treaties (VCLT). ${ }^{7}$ It is particularly significant for this study that the San José Court theorized a right to enjoy the benefits of scientific progress and its application in the field of reproductive rights. The comparative assessment of the approach of the two bodies paves the way to the elaboration of some proposals aimed at enhancing the theorization and the judicial protection of reproductive rights, for the purpose of theorizing a possibly generalized access to the applications offered by biomedical progress capable of ensuring appropriate respect for prenatal life. Interventions on human embryos are the main focus, and the reconstruction of a suitable international framework is developed by relying on Article 15 of the International Covenant on Economic, Social and Cultural Rights (ICESCR) ${ }^{8}$ and the relevant soft law, legal sources elaborated in the framework of the UNESCO, especially the regime of sharing of benefits contemplated in Article 19 of the UNESCO International Declaration on Human Genetic Data. ${ }^{9}$ At the same time, the limitations to viable and promising applications of scientific progress set by international law are analysed, with particular regard to the prohibition of human germline editing that, along with the prohibition of reproductive cloning, represents one

\footnotetext{
${ }^{7}$ United Nations, Vienna Convention on the Law of Treaties (adopted 23 May 1969, entered into force 27 January 1980) United Nations, Treaty Series, vol. 1155, p. 331, available at https://treaties. un.org/doc/publication/unts/volume\%201155/volume-1155-i-18232-english.pdf last accessed 4 June 2018.

${ }^{8}$ UN General Assembly, International Covenant on Economic, Social and Cultural Rights (adopted 16 December 1966, entered into force 3 January 1976) United Nations, Treaty Series, vol. 993, p. 3, available at last https://www.ohchr.org/en/professionalinterest/pages/cescr.aspx accessed 4 June 2018.

${ }^{9}$ UN Educational, Scientific and Cultural Organisation (UNESCO), International Declaration on Human Genetic Data (adopted 16 October 2003), available at http://portal.unesco.org/en/ev.phpURL_ID=17720\&URL_DO=DO_TOPIC\&URL SECTION=201.html last accessed 4 June 2018.
} 
of the two biomedical practices about which the international community has expressed a convergence of views.

In particular, the present study aims at identifying some common guarantees for reproductive rights, without disregarding prenatal life and the delicate pluralism of views in this field. This is also an exigency of social justice: whilst wealthy women can easily circumvent the preclusions met in their countries by seeking access to cross-border reproductive health care, the only option for poor women is often relying on clandestine remedies, that pose their health and even their life at serious risk. Besides "reproductive tourism", one of the main concerns is the risk of distorted and even eugenic uses of biomedicine, biotechnology and bioengineering, for examples those risks related to human embryo manipulation. Whilst such practice as mitochondrial replacement techniques (MRTs) and gene editing for preventing the onset of some genetic diseases may be fruitful therapeutic solutions, human germline alterations, now viable thanks to such promising techniques as CRISPR-Cas9, are seen as worrisome by the international community as they might jeopardize the essence of the human nature.

The approach, as to the legal area of reference, is based on international law, although some questions of constitutional law are tackled for complementing the view. The methodology adopted primarily relies on a multidisciplinary approach, in particular law and bioethics. However, also the interaction between law and medicine, law and biology, law and philosophy are considered, for the purpose of assessing the various factors that affect the approach to the beginning of life, the protection of the unborn and reproductive rights, especially in the framework of the COE and of the OAS. In this regard, also an integrative approach is adopted, since, the various implications - ethical, medical, biological, philosophical, social, cultural, historical - were considered in their interconnection and holistically. In particular, the research was carried out by primarily analysing the comprehensive understanding of the protection of the unborn and reproductive rights, in order to focus, subsequently, on the human rights systems of reference, in relation to their normative and jurisprudential landscape and possible weaknesses and strengths, for the purpose of advancing viable solutions as judicial cross-fertilization and interpretive paths consistent with the Vienna Convention on the Law of the Treaties.

\section{The status of human embryo and reproductive rights at the intersection between science and law}

Analysis of the legal perspective concerning prenatal life needs to move from the medical and biological premise, which plays a basic role in the framing of the legal regulation in this field at all levels of governance. Adequate debate 
between law and science is not always an easy task, especially in those cases where scientific progress has pushed so far to "overcome" the natural rule, which clearly leaves a regulatory gap that needs to be filled. Late Professor Stefano Rodotà, in one of his masterpieces, "Il dirito di avere diritti", has tackled the role of law in trying to describe and set the appropriate rule where the natural one requires to be somehow replaced. In particular, the role of the legal rule is supposed to be the "artificial reconstruction" of the natural bond that science and technology have extinguished. ${ }^{10}$ In fact, as was affirmed by Professor Daniel García San José, ${ }^{11}$ law usually lags behind science, as the latter is evolving at an impressive rate.

However, the risks of an inappropriate interference of the legislator when reproductive rights are at stake is not a remote possibility, and experience in the field shows this emblematically. Many examples may be recalled: sometimes the legislator criminalizes abortion, as it often happens in Latin America. In other cases, the legislator fails to translate social and scientific instances into an appropriate normative response, as it was interestingly the case of Italian Law No. 40/2004 on assisted reproductive technology (ARTs). ${ }^{12}$ In this respect, the role of protection and regional harmonization of human rights Courts is particularly important, and they can also help to provide the appropriate responses for replacing the legal rules that scientific progress may sweep away.

In this regard, it seems interesting to recall the metaphor used by Professor Roberto Cippitani in relation to the role of judicial scrutiny in "rejuvenating" anachronistic legal rules, uncapable of keeping the pace with scientific progress. ${ }^{13}$ Such rules are comparable to the protagonist of Scott Fitzgerald's story "The Curious Case of Benjamin Button", who was born old and got

${ }^{10}$ Rodotà, S., Il diritto di avere diritti, Editori Laterza, Roma-Bari, 2012, p. 285.

11 García San José, D.I., International Bio Law. An International Overview of Developments in Human Embryo Research and Experimentation, Murcia, Ediciones Laborum, 2010, pp. 149, 164, 179, 189, 192. Also see: García San José, D. I., European Normative Framework for Biomedical Research in Human Embryos, Cizur Menor, Aranzadi, 2013.

${ }^{12}$ For a wider analysis of the early version of Italian Law n. 40/2004, see Boggio, A., "Italy enacts new law on medically assisted reproduction", Human Reproduction, no. 20(5), (2005), pp. 11531157. See Penasa, S., "The Italian Law on assisted reproductive technologies N. 40 of 2004, facing the European Court of Human Rights: the case of Costa and Pavan v. Italy", Revista de Derecho y Genoma Humano/Law and the Human Genome Review, n³7, (2012), pp. 155-178, and Tigano, V., "La dichiarazione di illegittimità costituzionale del divieto di fecondazione eterologa: i nuovi confini del diritto a procreare in un contesto di perdurante garantismo per i futuri interessi del nascituro", Diritto Penale Contemporaneo, (13 June 2014) available at $<\mathrm{https}$ ://www.penalecontemporaneo.it/d/3141-ladichiarazione-di-illegittimita-costituzionale-del-divieto-di-fecondazione-eterologa-i-nuovi-conf $>$ last accessed 28 May 2018. Corte Costituzionale, Judgment n. 162 of 9 April 2014, para. 6.

${ }^{13}$ Cippitani, R., "The "curious case" of Italian Law no. 40 of 2004: how the dialogue between judges is modifying legislation on medically-assisted reproduction”, Rights and Science: R\&S, Vol. 0, (2017). Also see: Riezzo, I., Neri, M., Bello, S., Pomara, C., Turillazzi, E., "Italian law on medically assisted reproduction: do women's autonomy and health matter?", BMC Women's Health , n 16(1), (2016), pp. 16-44. For early analysis of Law n. 40/2004, see Fineschi, V., Neri, M., Turillazzi, E., "The new Italian law on assisted reproduction technology (Law 40/2004)", Journal of Medical Ethics, $\mathrm{n}^{\circ}$ 31(9), (September 2005), pp. 536-539.

Araucaria. Revista Iberoamericana de Filosofia, Politica, Humanidades y Relaciones Internacionales, año 20, $\mathrm{n}^{\circ} 40$. Segundo semestre de 2018. Pp. 655-732. ISSN 1575-6823 e-ISSN 2340-2199 doi: 10.12795/araucaria.2018.i40.27 
younger through his life. In a similar fashion, judicial scrutiny can rejuvenate old-fashioned and inadequate legal rules, and adjust them according to scientific evolution. Although Professor Cippitani referred to the impact of the decisions of the Italian Constitutional Court in relation to above-mentioned Law No. 40/2004, his reflection may reasonably be extended to international Courts. Of course, this reflection applies also the field of the protection of the unborn and reproductive rights. ${ }^{14} "{ }^{15}$ Nevertheless, judicial scrutiny of the interplay between law and science is not an easy task in this regard, first of all because the biological debate on the beginning of life is still open. The pluralism of views in the biological and in the legal landscape, especially with regard to the distinct views adopted by the national legal orders, makes the role of human rights Courts delicate. Some considerations on the issue seem necessary from this perspective.

The evolution of prenatal life follows three different stages after the moment of fecundation: the pre-embryonic, ${ }^{16}$ the embryonic and the foetal phase. After the fecundation, ${ }^{17}$ the union of the sperm and the egg triggers the process of the integration of both parents' DNA into the nucleus of the cell so created, the zygote, which begins to divide into undifferentiated cells that have totipotent nature. It means that each of these cells has the capacity of evolving into a separate embryo, ${ }^{18}$ a characteristic that is lost in only three-four days. During this pre-embryonic stage, that is set at the fifth-seventh day, the zygote evolves into the morula ${ }^{19}$ and, finally, into the blastocyst, which is made up of about one hundred pluripotent cells, each of which has the potential to develop into one of the two hundred types of cells of the human body. For evolving, the

${ }^{14}$ See: Casonato, C., "21st Century Biolaw”, Biolaw Journal - Rivista di Biodiritto, n 1, (2017); Casonato, C., "La scienza come parametro interposto di costituzionalità", Rivista dell'Associazione Italiana dei Costituzionalisti, $\mathrm{n}^{\circ} 2,(2016)$.

${ }^{15}$ Breyer, S., "Science in the Courtroom", Issues in Science and Technology, n 16(4), (Summer 2000), available at http://issues.org/16-4/breyer/ last accessed 28 May 2018 (the article is adapted from the introduction to the Reference Manual on Scientific Evidence, Second Edition (Federal Judicial Center, 2000). Also see Casonato, C., "La scienza come parametro interposto di costituzionalità", cited above n. 13. For a careful analysis on the precautionary principle in international jurisprudence, see CORTI, J., "El principio de precaución el la jurisprudencia internacional", Revista Epañola de Derecho Internacional, ${ }^{\circ}$ 69(1) (2017), pp. 219-243.

${ }_{16}$ The conception of pre-embryo was advanced by the developmental biologist Anne Laura Dorinthea McLaren in 1986. See López Moratalla, N., "Fecundación" (Enciclopedia de Bioderecho y Bioética) available at https://enciclopedia-bioderecho.com/voces/134 last accessed 28 May 2018; Khokhar, A., "Anne Laura Dorinthea McLaren (1927-2007)", The Embryo Project Enciclopedia, available at https://embryo.asu.edu/pages/anne-laura-dorinthea-mclaren-1927-2007 last accessed 28 May 2018. See Jones, G., Telfer, B., "Before an embryo I was a pre-embryo: or was I?", Bioethics, $\mathrm{n}^{\circ}$ 9(1) (January 1995), pp. 32-49.

${ }^{17}$ López Moratalla, N., "Fecundación", cited above n. 15.

${ }^{18}$ Laurie, G., "Patenting Stem Cells of Human Origin", Property Review at [2004] EIPR pp. 59 ff.; Femenía López, P.J., "Embrión (jurídico)” (Enciclopedia de Bioderecho y Bioética) available at https:/enciclopedia-bioderecho.com/voces/135 last accessed 28 May 2018.

19 The morula is an early stage embryo made of cells called blastomeres, contained within the zona pellucida.

Araucaria. Revista Iberoamericana de Filosofía, Política, Humanidades y Relaciones Internacionales, año 20 , $\mathrm{n}^{\circ} 40$. Segundo semestre de 2018. Pp. 655-732. ISSN 1575-6823 e-ISSN 2340-2199 doi: 10.12795/araucaria.2018.i40.27 
Human Rights and the European Court of Human Rights

blastocyst needs proper environment, that provides it with appropriate nutrition: that means that it needs the implantation ${ }^{20}$ in the lining of the womb, a process that begins at about day eight ${ }^{21}$ and terminates at about day fourteen-fifteen,

${ }^{20}$ During the process of implantation, the trophoblasts, namely the cells constituting the external layer of the blastocyst, adhere to the endometrium, and are destined to concur to form the placenta. The blastocyst also contains other two types of cells: those that form the primitive endoderm, on which the proper development of foetus' organs will depend and which will ensure that essential nutrients are provided. Moreover, the inner cell mass of the blastocyst, the epiblast is made up of the cells that will constitute the future body of the foetus, that are embryonic stem cell which will differentiate in the three germ layers, endoderm (inner layer, that will form many of the inner lining of the body, as the lungs, the liver and the pancreas), the ectoderm (outer layer, which will form the outer lining of the body, as the epidermis, the hair, but also the peripheral nervous system), and the mesoderm (middle layer, which is set between the endoderm and the ectoderm and which will form other tissues of the body, as the heart, the bone marrow and, thus, the blood, the muscle system, the dermis). See "Embrione" in Enciclopedia Treccani available at http://www.treccani.it/enciclopedia/ embrione-umano_\%28Enciclopedia-Italiana\%29/ last accessed 28 May 2018. "Scientists develop human embryos beyond implantation stage for first time" (University of Cambridge, 4 May 2016) available at https://www.cam.ac.uk/research/news/scientists-develop-human-embryos-beyondimplantation-stage-for-first-time last accessed 28 May 2018. Again, see: See YU, J., Thomson, J.A., "Human embryonic stem cells", available at https://stemcells.nih.gov/info/Regenerative Medicine/2006Chapter1.htm last accessed 28 May 2018. See: Kiessling, A. A., Anderson, S. C., Human Embryonic Stem Cells: An Introduction to the Science and Therapeutic Potential, Sudbury, Boston, Toronto, London, Singapore, Jones and Bartlett Publishers, 2003; National Research Council, Institute of Medicine, Board on Health Sciences Policy, Division on Earth and Life Studies, Board on Life Sciences, Committee on Guidelines for Human Embryonic Stem Cell Research, Guidelines for Human Embryonic Stem Cell Research (The National Academies Press, 2005); Masters, J. R., Palsson, B. O., Thomson. J. A., (eds.), Embryonic Stem Cells, Dordrecht, Springer, 2007; TURKSEN, K., (ed.), Adult and embryonic stem cells, New York, Dordrecht, Heidelberg, London, Human Press, Springer, 2012. It seems interesting to remind here that adult stem cells and blood cordon stem cells, otherwise, are multipotent, which means that they have the capacity to develop into more than one cell type. For deepening the analysis, see: DODET, B., VICARI, M., (eds.), Pluripotent Stem Cells: Therapeutic Perspectives and Ethical Issues, Montrouge, John Libbey Europext, 2001, pp. $42 \mathrm{ff}$. It could be interesting to have a closer look to two important functional properties of the embryonic stem cells, namely the asymmetric division, which produces two distinct daughter cells, in particular one copy of the original stem cell and second daughter programmed to differentiate into a non-stem cell fate, and the clonogenic capacity, that means they can divide infinitely. In this respect, see: Knoblich, J. A., "Mechanisms of Asymmetric Stem Cell Division", Cell, n' 132(4), (22 February 2008), pp. 583-597; Lusis, M., Li, J., Ineson, J., Christensen, M.e., Rice, A., Little, M.h., "Isolation of clonogenic, long-term self-renewing embryonic renal stem cells", Stem Cell Research, n ${ }^{\circ}$ 5(1), (July 2010), pp. 23-39; Gómez-López, S., Lerner, R. G., Petritsch, C., "Asymmetric cell division of stem and progenitor cells during homeostasis and cancer", Cellular and Molecular Life Science, $\mathrm{n}^{\circ}$ 71(4), (2014), pp. 575-597. Winograd, C., "Germ layer", Encyclopedia Britannica, available at https://www. britannica.com/science/germ-layer last accessed 28 May 2018.

${ }^{21}$ For an interesting analysis, which highlights the critical aspects and tries to shed some light from a close biological viewpoint, see: Findlay, J. K., Gear, M. L., Illingworth, P.j., Junk, S.m., Kay, G., Mackerras, A.h., Pope, A., Rothenfluh, H.s., Wilton, L., "Human embryo: a biological definition", Human Reproduction, $\mathrm{n}^{\circ}$ 22(4), (2007), pp. 905-911. De Miguel Beriain, I., 'What is a human embryo? A new piece in the bioethics Puzzle', Croatian Medical Journal, ${ }^{\circ}$ 55, (2014), pp. 669-671. Evans, D., Pickering, N., Conceiving the Embryo: Ethics, Law, and Practice in Human Embryology, The Hague, London, Boston, Martinus Nijhoff Publishers, 1996. The phase of implantation in the lining of the womb is called "implantation window". The "implantation window" is made of three phases: the apposition, which depends on the maturation of the endometrium, the adhesion and the embedding in the endometrium. For wider overview, see: Harper, M. J., "The implantation window", Baillière's Clinical Obstetrics and Gynaecology, n 6(2), (1992), pp. 351-71; Achache, H., Revel, A., "Endometrial receptivity markers, the journey to successful embryo implantation", Human

Araucaria. Revista Iberoamericana de Filosofia, Política, Humanidades y Relaciones Internacionales, año 20, ${ }^{\circ} 40$. Segundo semestre de 2018. Pp. 655-732. ISSN 1575-6823 e-ISSN 2340-2199 doi: 10.12795/araucaria.2018.i40.27 
when the blastocyst can be finally called embryo. ${ }^{22}$ At about the fourteenthfifteenth day two important evolutions occur for the debate on the beginning of life, namely the appearance of the first signs of the nervous system, that is the primitive streak, and the end of the phase during which the twinning process is still possible, since until that moment the embryo can still divide into other embryos or the distinct zygotes may recombine into one. ${ }^{23}$ After implantation, the embryo ${ }^{24}$ continues to develop and, at about eight weeks pregnancy, the foetal stage finally begins, to last until the end of pregnancy. ${ }^{25}$

In the biological debate, the discussion on some issues is still open: the theory of the pre-embryonic stage, which dates back to 1986 , when Dr. McLaren advanced it, has not received generalized acceptance in the scientific community. What is more, possibly even more importantly for our purposes, the scientific community is split with regard to the definition of the moment when life begins, whether at conception or, otherwise, through a progressive process, which would imply growing protection during the evolution from conception to birth. ${ }^{26}$ Again, another view was advanced, in this case mainly

$\overline{\text { Reproduction Update, }} \mathrm{n}^{\circ}$ 6(12), (2006), pp. 731-746. For a brief description of implantation and its different stages, see "Human embryology - Embryogenesis" available at http://www.embryology.ch/ anglais/gnidation/resumenidation01.html last accessed 28 May 2018. See: LORÉ, C., Fra scienza e società, Milano, Giuffré, 2008, pp. $22 \mathrm{ff}$.

22 Andorno, R., La bioética y la dignidad de la persona, Madrid, Editorial Tecnos - Grupo Anaya, 2012, pp. 120, 121.

${ }^{23}$ Shea, M. C., "Embryonic life and human life", Journal of medical ethics, $\mathrm{n}^{\circ}$ 11, (1985), pp. 205-209.

${ }^{24}$ It seems interesting to recall here that embryonic stem cells represent a particularly valuable resource for research and for therapeutic horizons, as they could help to treat various diseases, as immune system-related genetic diseases, degenerative diseases and cancer. This is so because of their properties: first, they are pluripotent that, as anticipated above, means that they have the potentiality to evolve into any of the two hundred cell types that make up the human body. Moreover, they have the ability to replicate infinitely. The characteristics of embryonic stem cells allow significant possibilities of use in research, for example in the field of regenerative medicine and for tissue replacement. For wider analysis, see: 'Embryonic stem cells' (Science Daily) available at https:/www.sciencedaily. com/terms/embryonic_stem_cell.htm last accessed 28 May 2018. See: Kiessling, A. A., Anderson, S. C., Human Embryonic Stem Cells: An Introduction to the Science and Therapeutic Potential, cited above n. 19; Masters, J. R., Palsson, B. O., Thomson. J. A., (eds.), Embryonic Stem Cells, cited above n. 19; Turksen, K., (ed.), Adult and embryonic stem cells, cited above n. 19. It is important to remind the distinction between stem cells and immortalized cells. See: Freshney, R. I., Stacey, G. N., Auberbach, J. M., Culture of immortalized cells, Hoboken, Wiley, 1996; Macieira-Coelho, A., Cell immortalization, Verlag, Berlin, Heidelberg, Springer, 2000; Irfan Maqsood, M., Matin, M. M., Bahrami, A. R., Ghasroldasht, M. M., "Immortality of cell lines: Challenges and advantages of establishment", Cell Biology International, n 37(10), (2013), pp. 1038-1045.

${ }^{25}$ Laurie, G., "Patenting Stem Cells of Human Origin", cited above n. 17, pp. 59 ff. Femenía López, P.J., "Embrión (jurídico)", cited above n. 17.

26 Naturally, the discourse on the definition of the beginning of life has been tackled by philosophical thought as well. The beginning of the debate dates back to IV century B.C. and the theory of the ensoulment of the embryo elaborated by Aristotle, that encompassed three stages, which were respectively characterized by the nutritive, the sensitive and the rational soul. Saint Thomas Aquinas took up and enunciated the Aristotelian theory of ensoulment in the Summa Theologica, thus reaffirming that ensoulment would occur for baby boys at the fortieth day of pregnancy and for baby girls at the eightieth, being quickening an indication of the soul. Abortion was allowed within those Segundo semestre de 2018. Pp. 655-732. ISSN 1575-6823 e-ISSN 2340-2199 doi: 10.12795/araucaria.2018.i40.27 
Human Rights and the European Court of Human Rights

from a philosophical viewpoint, according to which the belonging to the human species is inscribed in the genome and, therefore, conception is the moment to consider for defining the beginning of life. ${ }^{27}$ The variety of perspectives characterizes also the legal debate on the status of the unborn and whether it has the right to life according to national law, although, in general, domestic legal orders, birth is determinant for the acquisition of personhood ${ }^{28}$ and the unborn receives only limited protection, for example in the field of succession

terms. On these issues, see: Andorno, R., La distinction juridique entre les personnes et les choses à l'épreuve des procréations artificielles, Paris, L.G.D.J., Bibliothèque de droit privé, 1996, pp. $113 \mathrm{ff}$. Andorno, R., La bioética y la dignidad de la persona, cited above n. 21, pp. 109 ff. Also see: Jones, D. A., Soul of the Embryo: an enquiry in the status of the human embryo in the Christian tradition, London, New York, Continuum, 2004, pp. $225 \mathrm{ff}$. During the centuries the theory of ensoulment was set aside, and States' relevant approaches were in huge part related to the criminal theories of the 1800 . For example, Italian positivist school considered abortion and infanticide crimes capable of raising limited social concern. In this regard, see: Lombroso, C., Peset Reig, J. L., Peset Reig, M., Lombroso y la escuela positivista italiana (Ediciones Castilla, Madrid, 1975). For some comparison between naturalism and positivism in relation to abortion: HELLOJ173 "Abortion: Natural vs. Postivist Law", Law and Society@Kwantlen, (1 December 2012) available at https://kpulawandsociety.wordpress. com/2012/12/01/abortion-natural-vs-postivist-law/ last accessed 28 May 2018. Eventually, the issue of ensoulment was reinvigorated in the 1970s by the advent of in vitro fertilization.

${ }^{27}$ Andorno, R., La bioética y la dignidad de la persona, cited above n. 21, pp. 110-112. Andorno, R., La distinction juridique entre les personnes et les choses à l'épreuve des procréations artificielles, cited above n. 25, pp. 113 ff. For further analysis, also see: Crosby, J. B., "The personhood of the human embryo", The Journal of Medicine and Philosophy, $\mathrm{n}^{\circ}$ 18(4), (1993), pp. 399-417. With regard to the debate on the stats of the human embryo, Professor Roberto Andorno has stressed that definition of this issue is a philosophical rather than biological task, and has expressed some criticism about those theories which would condition personhood on the achievement of a given stage of embryonic development. In this respect, indeed, four stages were highlighted as suitable moments for affirming the acquisition of personhood, first of all the achievement of the fourteenth day since fertilization, as finally the primitive streak appears and embryonic tissues begin to differentiate. Moreover, another argument for this view is that since this moment twinning cannot occur anymore, which was also used as a statement in support of the acquired individuality of the embryo. For wider analysis, see: Andorno, R., La distinction juridique entre les personnes et les choses à l'épreuve des procréations artificielles, cited above n. 25, pp. 120-123. For analysis of the critics to this view, see again Andorno, R., La bioética y la dignidad de la persona, cited above n. 21, pp. $113 \mathrm{ff}$. Eight weeks is another stage that was taken into consideration by the "brain life theory", which would connect personhood to the development of a functioning brain; however, this view is criticized by those who also require the development of the "critical system of the brain", which can be found at twenty weeks and which is the substrate for such functions as feeling sensations, memory, self-consciousness and learning. Finally, another theorization suggested that personhood would be acquired some time after birth, when the child develops his or her own self-awareness. For further analysis see SHEA, M. C., "Embryonic life and human life", cited above n. 22, who embraces the view that human life begins "when the newly developing body organs and systems begin to function as a whole [...] [that] is symmetrical with the death of an existing human life, which occurs when its organs and systems have permanently ceased to function as a whole".

${ }^{28}$ It is interesting to recall here that roman law recognized the 'conceptus' as a person, with considerable consequences, since important legal institutions and effects, as the acquisition of citizenship and of the status of free man, were related to conception and not to birth. Andorno, R., La bioética y la dignidad de la persona, cited above n. 21, p. 120. Also see: Mousourakis, G., Fundamentals of Roman Private Law, Heidelberg, New York, Dordrecht, London, Springer, 2012, pp. $85 \mathrm{ff}$. For widening the analysis: Westra, L., Environmental Justice and the Rights of Unborn and Future Generations: Law, Environmental Harm and the right to health, Abingdon, New York, Earthscan, 2006, pp. 32 ff. 
law. ${ }^{29}$ Some important attempts to that attempts to define the legal status of the unborn in relation to reproductive rights can be found in the jurisprudence of the Constitutional Courts around the world. In this regard, the principle of human dignity has played a basic role. An emblematic example is offered by the French Conseil Constitutionel, ${ }^{30}$ when it was called on to express its view on abortion rights in relation to Article 16 of the Code Civil, ${ }^{31}$ which protects life since conception. ${ }^{32}$ The Court clarified that the Code Civil grants protection to the human embryo and, then, to the foetus in light of the potential of life they embody, which justifies constitutional protection in relation to the principle of human dignity. At the same time, the Conseil Constitutionel also specified that this does not change the fact that legal personhood is acquired at the moment of birth, nor it precludes the protection of the right to abortion of the mother. ${ }^{33}$ In a similar vein, with regard to ARTs, the Italian Corte Costituzionale clarified that,

${ }^{29}$ Italy, Poland and South Africa could be cited as examples in this regard. More in particular, in this respect it is interesting to highlight a peculiar jurisprudential elaboration that emerged in Italy, until the United Chambers of the Supreme Court of Cassation (Corte di Cassazione, Sezioni Unite, Judgment n. 25767, of 22 December 2015) denied its existence, due to an intimate ontological contradiction. In Italy, the right not to be born if not healthy began to emerge jurisprudentially: in case of missed diagnosis of the disease affecting the foetus, the doctor was to be held responsible towards the child borne in a condition of impairment, as the mother had not had the chance to abort. The Court of Cassation, in late 2015, has put in evidence the contradictions of such conception, stressing that Italian law does not contemplate the right not to live and the eugenic risks that a similar view would entail. It goes without saying that no right nor protection was accorded to the nasciturus. Again, affirmation of medical responsibility towards the child in case of pregnancy damages postulates birth. In this regard, see Gaudino, F., "Responsabilità medica: è inesistente il diritto a non nascere se non sano", Diritto 24, (9 February 2016) available at <http:/www.diritto24.ilsole24ore.com/art/ dirittoCivile/responsabilita/2016-02-09/responsabilita-medica-e-inestistente-diritto-non-nascerese-non-sano-180126.php?refresh_ce=1> last accessed 28 May 2018. In relation to abortion and the nasciturus from an Italian perspective, see: La Civiltà cattolica, Edizioni 3043-3048, Anno 128 Volume II - Quaderno 3043 - 2, (Aprile 1977), pp. 3 ff.

${ }^{30}$ Conseil Constitutionel, 21 janvier 2016, n 2015-727 DC: «Considérant, d'une part, qu'en supprimant le délai d'une semaine entre la demande de la femme d'interrompre sa grossesse et la confirmation écrite de cette demande, le législateur n'a pas rompu l'équilibre que le respect de la Constitution impose entre, d'une part, la sauvegarde de la dignité de la personne humaine contre toute forme de dégradation et, d'autre part, la liberté de la femme qui découle de l'article 2 de la Déclaration de 1789, dès lors que l'article L. 2212-5 du code de la santé publique dans sa rédaction résultant de l'article 82 fait obstacle à ce que la demande d'interruption de grossesse et sa confirmation écrite interviennent au cours d'une seule et même consultation.»

31 Article 16 of the Code Civil provides that: «La loi assure la primauté de la personne, interdit toute atteinte à la dignité de celle-ci et garantit le respect de l'être humain dès le commencement de sa vie»».

${ }^{32}$ Hartman, F., "Conciliation entre l'interruption volontaires de grossese et le respect de la vie et de la dignité humaine", Le droit des personnes et de la famille à l'épreuve des droits fondamentaux présenté par l'IEJ de Paris 1 (Université Paris 1 Panthéon-Sorbonne, 20 July 2016) available at $<$ https://iej.univ-paris1.fr/openaccess/libertes-famille/lecon1/sect1/i/a-ivg-respect-vie-dignite/> last accessed 28 May 2018.

33 Furthermore, French abortion law, liberalized by the Veil Law in 1975, is a permissive one: abortion is legal on demand up to twelve weeks after conception, and it is allowed at later stages of pregnancy whether two physicians certify that it aims to prevent grave permanent injury to the physical or mental health of the mother or in case her life is at risk, and again if the child will suffer from a particularly severe illness recognized as incurable.

Araucaria. Revista Iberoamericana de Filosofía, Política, Humanidades y Relaciones Internacionales, año 20, $\mathrm{n}^{\circ} 40$ Segundo semestre de 2018. Pp. 655-732. ISSN 1575-6823 e-ISSN 2340-2199 doi: 10.12795/araucaria.2018.i40.27 
as the human embryo enshrines the beginning of life, it deserves constitutional protection on the grounds of Article 2 of the Italian Constitution, which as to be read as granting constitutional relevance to human embryo's dignity. ${ }^{34}$ In a similar fashion, in the American continent, Judge Sergio Valls distinguished the right to life and life as a moral good in his Concurring Opinion in the joined cases No. 146/2007 and No. 147/2007 before the Colombian Suprema Corte Constitucional, and clarified that the right to life, as a subjective right, refers to the human person as a rights-bearer, contrarily to "the protection of life in general, which also concerns those who still have not [the capacity to hold and exercise subjective rights], including the unborn, thus it consists in potential life". ${ }^{35}$ Interestingly, the Spanish Tribunal Constitucional, ${ }^{36}$ that has embraced the conception of the progressive development of life, ${ }^{37}$ has affirmed that human embryo should enjoy a specific status. ${ }^{38}$ Although the human embryo,

${ }^{34}$ Corte Costituzionale, Judgment n. 84 of 13 April 2016, para. 8.2, available at http://www. federalismi.it/ApplOpenFilePDF.cfm?artid=31711\&dpath=document\&dfile=13042016135147.pdf $\&$ content $=$ Corte + Costituzionale,+ Sentenza + n. $+84 / 2016,+\mathrm{in}+$ tema $+\mathrm{di}+$ procreazione + medicalmente +assistita,+sperimentazione+sugli+embrioni+umani.+-+stato+-+documentazione+-+ last accessed 1 June 2018. In this regard, also see: Corte Costituzionale, Judgment n. 151 of 1 April 2009, available at https://www.cortecostituzionale.it/actionSchedaPronuncia.do?anno=2009\&numero=151 last accessed 1 June 2018; Corte Costituzionale, Judgment n. 229 of 21 October 2015, available at https:// www.cortecostituzionale.it/actionSchedaPronuncia.do 2 anno $=2015 \&$ numero $=229$ last accessed 1 June 2018.

${ }^{35}$ Concurring Opinion of Judge Sergio Valls Hernández, Suprema Corte Constitucional, joined cases $n^{\circ} 146 / 2007$ and $n^{\circ} 147 / 2007$ (Voto concurrente que formula el Ministro Sergio Valls Hernández, en la acción de inconstitucionalidad 146/2007 y su acumulada 147/2007), p. 2. The Mexican Constitutional Court has been interestingly proactive in the affirmation and the protection of reproductive rights. In this regard, an overview of the Court's jurisprudence can be found in Madrazo, A., Vela, E., "The Mexican Supreme Court's (Sexual) Revolution?”, Texas Law Review, n 89, (2011), pp. 1863-1893.

${ }^{36}$ In this regard see: Tribunal Constitucional, Judgment n. 53 of 11 April 1985, available at http://hj.tribunalconstitucional.es/ca/Resolucion/Show/433 last accessed 28 May 2018; Tribunal Constitucional, Judgment n. 212 of 19 December 1996, available at http://hj.tribunalconstitucional.es/ ca/Resolucion/Show/3264 last accessed 28 May 2018; Tribunal Constitucional, Judgment n. 116 of 17 June 1999, available at http://hj.tribunalconstitucional.es/gl/Resolucion/Show/3858 last accessed 28 May 2018.

37 The Spanish debate is particularly interesting. Authoritative scholarship has called for a more specific definition of the status and the personhood of the human embryo, since its lack may pose the risk that embryo is considered as a material thing, if its evolution is intended as the "development towards being a human being" instead of the "development of a human being". This view was held also with particular reference to the embryo in vitro, whose personhood was affirmed by those scholars who prioritize the protection of its life and was denied by those who support freedom of research and identify a set of prevalent entitlements related to the enjoyment of scientific progress for the future and possibly also the current generations. In this regard, for a wider analysis, see: Ruiz de la Cuesta, A., "El debate doctrinal sobre el principio de la protección de la vida humana. Una lectura crítica desde la concepción gradualista o progresiva", in García San José, D. I., (ed.), Marco Jurídico Europeo relativo a la Investigación Biomédica en Transferencia Nuclear y Reprogramación Celular, Sevilla, Thomson Reuters-Aranzadi 2012, pp. 25 ff. Also see: Romeo Casabona, C. M., "El estatuto jurídico del embrión humano", Revista de Humanidades Médicas, n 8(4), (2007), pp. 111-124 and Ollero, A., "El estatuto jurídico del embrión humano", in Ballesteros Llompart, J., Fernández Ruiz-Gálvez, E., (eds.), Biotecnología y posthumanismo, Burgos, Thomson Reuters-Aranzadi, 2007, pp. 339 ff.

${ }^{38}$ For deeper analysis see Romeo Casabona, C. M., "El estatuto jurídico del embrión humano", cited above n. 36. 
including the embryo in vitro, does not have the right to life, protected under Article 15 of the Spanish Constitution, nor it has legal personhood, it cannot be compared to material things as to its status, therefore the protection granted to constitutionally protected legal goods has to be ensured. This affirmation is all the more significant when one considers that Spanish legislation concerning human embryo research is one of the most advanced in the world and, for instance, allows the use of supernumerary embryos for research purposes. ${ }^{39}$ In Latin America, a similar view can be found, emblematically, in the jurisprudence of the Corte Constitucional de Colombia, that distinguished life as a "moral good" from life as a "legal good". ${ }^{40}$ In some countries, the protection of the unborn is enshrined in the Constitutional texts and affects the margin of discretion of the legislator when dealing with reproductive rights: for example the Constitution of Ecuador ${ }^{41}$ protects the right to life from conception and the Constitution of Chile ${ }^{42}$ protects the life of the "one who is going to be borne". Again, the Irish Constitution ${ }^{43}$ ensures protection to the right to life of

39 Vicente Giménez, T., Marzocco, V., Pozzolo, S., Farano, A., "La Subjetividad Político-Jurídica de Las Mujeres y La Biotecnología Como Política De Reproducción", Revista Bioderecho.es Revista Internacional de Investigación en Bioderecho, $\mathrm{n}^{\circ} .3,(2016)$, available at http://revistas.um.es/ bioderecho/article/view/260301 last accessed 28 May 2018.

${ }^{40}$ C-355/2006 de la Corte Constitucional de Colombia. See Javier Aguirre Román, “Análisis de la sentencia C-355 de 2006 de la Corte Constitucional sobre la liberalización del aborto en Colombia: argumentos iusfilosóficos que sustentan el debate en el marco de la perspectiva de Habermas sobre el rol de la religión en la esfera pública. Estudios Socio-Jurídicos", Estudios Socio-Jurídicos, [S.1.], 17(2) (2015), 167-198.

${ }^{41}$ Article 45 of the Constitution of Ecuador provides that: “[...] El Estado reconocerá y garantizará la vida, incluido el cuidado y protección desde la concepción [...]”.

42 Article 19 of the Constitution of Chile - adopted under the regime of Augusto Pinochet, in 1980 provides that " $1{ }^{\circ} \mathrm{El}$ derecho a la vida y a la integridad física y psíquica de la persona. $2^{\circ} \mathrm{La}$ ley protege la vida del que está por nacer". The second paragraph is the relevant one where it foresees that "[t]he law protects the life of those about to be born". Abortion for medical reasons was legalized in Chile in 1931, but an absolute ban on it was set under Pinochet's regime in 1989. Now, in Chile, abortion is allowed in three cases: 1) when mother's life is at risk; 2) in case of rape during the first 12 weeks of pregnancy (14 weeks, if the woman is under 14 years old); 3) when the foetus will not survive the pregnancy. The bill decriminalizing abortion under those circumstances was approved by the National Congress in August 2017 and become law one month later. The role of President Michelle Bachelet was of primary importance in the promotion of a bill that reflected the view of the vast majority of the Chilean people - about the $70 \%$, according to an opinion poll conducted by the research firm Cadem. Reuters, "Chile passes bill to legalize abortion in certain cases", The Guardian, 19 July 2017 available at https:/www.theguardian.com/world/2017/jul/19/chile-abortion-mother-rape-life-legalization last accessed 15 June 2018; SUMMERS, H., "Endgame nears in Chile president's fight to temper draconian abortion ban", The Guardian, 16 August 2017, available at https://www.theguardian.com/ global-development/2017/aug/16/chile-abortion-ban-constitiutional-tribunal-michelle-bachelet last accessed 15 June 2017; Kozak, O., “AA triumph of reason': Chile approves landmark bill to ease abortion ban", The Guardian, 22 August 2017, available at https:/www.theguardian.com/globaldevelopment/2017/aug/22/chile-abortion-bill-michelle-bachelet-a-triumph-of-reason-ease-abortionban last accessed 15 June 2018 .

43 The relevant provision is Article 40(3) of the Irish Constitution, which provides that: "the State acknowledges the right to life of the unborn and, with due regard to the equal right to life of the mother, guarantees in its laws to respect, and, as far as practicable, by its laws to defend and vindicate that right". In this regard see: Lawson, R., "The Irish abortion cases: European limits to national 
the unborn and to "the equal right to life of the mother" and the Constitution of Venezuela ${ }^{44}$ provides some conceptualization of parenthood and reproductive rights and protects the rights of the mother since conception. ${ }^{45}$

Moreover, the nature of reproductive rights itself determines some pluralism in their implementation at the domestic level:46 in fact, as some scholars have stressed, "conceptually, they are not independent rights, but are drawn from other recognized human rights". ${ }^{47}$ In particular, reproductive rights, which encompass both the right to reproductive health care and the right to reproductive self-determination, ${ }^{48}$ are drawn from the right to health, the right to physical integrity, the right to private life, the right to autonomy, the right to equality. ${ }^{49}$ In this regard, it is interesting to recall the words of Sofia

sovereignty?", European Journal of Health Law, n 1, (1994), pp. 167-186.

${ }^{44}$ The Constitution of Venezuela protects the right to life at Article 43, which affirms its inviolability ("El derecho a la vida es inviolable"). The more targeted provision, for our purposes has to be sought at Article 76, which protects paternity and maternity, with a provision that reminds of the tenor of the 1994 International Conference on Population and Development (ICPD) and of the Cairo Conference on Population and Development where it affirms parents' right to decide the number of their children and right to access to the information and the means necessary for this purpose. Namely, Article 76 foresees that: "La maternidad y la paternidad son protegidas integralmente, sea cual fuere el estado civil de la madre o del padre. Las parejas tienen derecho a decidir libre y responsablemente el número de hijos e hijas que deseen concebir y a disponer de la información y de los medios que les aseguren el ejercicio de este derecho. El Estado garantizará asistencia y protección integral a la maternidad, en general a partir del momento de la concepción, durante el embarazo, el parto y el puerperio, y asegurará servicios de planificación familiar integral basados en valores éticos y científicos". This clause can be translated in English as follows: "Motherhood and fatherhood are fully protected, whatever the marital status of the mother or father. Couples have the right to decide freely and responsibly how many children they wish to conceive, and are entitled to access to the information and means necessary to guarantee the exercise of this right. The State guarantees overall assistance and protection for motherhood, in general, from the moment of conception, throughout pregnancy, delivery and the puerperal period, and guarantees full family planning services based on ethical and scientific values".

${ }_{45}$ With regard to the protection of the unborn and reproductive rights in Latin American, with particular reference to abortion, it is interesting to listen to the conference held by Dr. Sonia Corrêa on the topic "Abortion frontlines: the Latin American context" at the London School of Economics and Political Science (LSE Law), in the academic year 2016/2017, available at https://www.youtube. com/watch?v=WdT06QW26Tg last accessed 28 May 2018. Also see: ARCHIMEDES, S., Gendered Pathologies: The Female Body and Biomedical Discourse in the Nineteenth Century English Novel, London, New York, Routledge, 2005, p. 114.

${ }^{46}$ In this regard, it may be interesting to recall a passage from the above-mentioned Judgment $\mathrm{n}$. 164/2014 of the Italian Constitutional Court (namely, an excerpt from para.6 of the decision), where it clarified that "the choice [...] to become parents and to found a family that includes the offspring constitutes the expression of the fundamental and general freedom of self-determination which, as this Court has affirmed although with regard to distinct ends and in a different context, can be drawn from articles 2, 3 and 31 of the Constitution, since it concerns the private and family sphere [of an individual]" (the passage from the Italian text of the Judgment reads: "la scelta [...] di diventare genitori e di formare una famiglia che abbia anche dei figli costituisce espressione della fondamentale e generale libertà di autodeterminarsi, libertà che, come questa Corte ha affermato, sia pure ad altri fini ed in un ambito diverso, è riconducibile agli artt. 2, 3 e 31 Cost., poiché concerne la sfera privata e familiare".

${ }^{47}$ Stopler, G., "Reproductive rights", Max Planck Encyclopedia of Comparative Constitutional Law [MPECCoL], 2017.

${ }^{48}$ Ibid.

${ }^{49}$ Ibid. 
Gruskin, who held that "human rights provide an international legal framework within which the sexual and reproductive health needs and aspirations of all people can be considered". ${ }^{50}$

It is in this pluralistic and sensitive scenario that international law and international human rights bodies are called on to provide some shared standard and adequate responses in order to foster a conceptualization and an implementation of reproductive rights respectful of the unborn and capable of keeping the pace with scientific progress. It is a basic goal for ensuring a human rights-consistent scientific evolution.

\section{The status of human embryo and reproductive rights in international law}

The pluralism of views that emerges from the biological debate and the legal domestic scenario has made and still makes hard the elaboration of shared human rights conceptualization and standards for reproductive rights. However, some common understanding can be found in international hard and soft law, especially thanks to the interpretive efforts of human rights bodies. This is so notwithstanding international law offers scant targeted references. An early attempt of conceptualization of reproductive rights was made in the context of the 1994 International Conference on Population and Development (ICPD), held in the framework of the United Nations Population Fund (UNFPA), also known as the Cairo Conference on Population and Development. The 1994 Cairo Programme of Action, ${ }^{51}$ when defining reproductive health as "a state of complete physical, mental and social well-being and not merely the absence of disease or infirmity, in all matters relating to the reproductive system and to its functions and processes", also specified that it implies the capability and freedom to reproduce if and when desired. ${ }^{52}$ This notion also clarified that reproductive rights "rest on the recognition of the basic right of all couples and individuals to decide freely and responsibly the number, spacing and timing of their children and to have the information and means to do so, and the right to attain the highest standard of sexual and reproductive health". This statement is particularly important and induced Barbara Crossette, former United Nations

${ }^{50}$ Gruskin, S., (ed.), Perspectives in Health and Human Rights (Taylor and Francis, Routledge, London, 2005).

${ }^{51}$ United Nations Population Fund, Programme of Action-Adopted at the International Conference on Population and Development (ICPD), 5-13 September 1994 (United Nations Population Fund, 2004) available at https://www.unfpa.org/sites/default/files/event-pdf/PoA_en.pdf last accessed 28 May 2018.

52 This definition of sexual health was provided on the occasion of 1994 International Conference on Population and Development (ICPD). See World Health Organization, Sexual health and its linkages to reproductive health: an operational approach, (World Health Organization, Geneva, 2017), available at http://apps.who.int/iris/bitstream/handle/10665/258738/9789241512886-eng.pd f;jsessionid=5AAD8749B3FEAC851C874B9E1C6816E1?sequence=1 last accessed 28 May 2018.

Araucaria. Revista Iberoamericana de Filosofía, Política, Humanidades y Relaciones Internacionales, año 20, $n^{\circ} 40$. Segundo semestre de 2018. Pp. 655-732. ISSN 1575-6823 e-ISSN 2340-2199 doi: 10.12795/araucaria.2018.i40.27 
Bureau Chief of The New York Times, ${ }^{53}$ to say that "out of Cairo came no less than a revolution". ${ }^{4}$ The "revolution" lies in the recognition that "people - women and men, mothers and fathers - not governments were the best judges of how many children to bring into the world, and where and when". ${ }^{55}$ This statement represents an acknowledgment of the prevalence of individual autonomy over State's interference in the reproductive field, an interference occasionally consisting in the imposition of an ethics conceived as a State prerogative. ${ }^{56}$ Moreover, consistently with their nature of "non-independent rights", the 1994 Cairo Programme of Action also clarifies that "[r]eproductive rights embrace certain human rights that are already recognized in national laws, international human rights documents and other relevant UN consensus documents". A similar definition of reproductive rights can be found in the framework of the World Health Organization (WHO) that, in the 2000s, made an important effort to conceptualize reproductive rights through the elaboration of the working definitions of "sexual health" and of the related conceptions of "sex", "sexuality" and "sexual rights". 57 The conception of "sexual rights" elaborated reminds of the 1994 Cairo Programme of Action where it contemplates "the right to decide the number and spacing of one's children"

\footnotetext{
${ }^{53}$ In particular, Ms. Crossette made this remark on the occasion of the thirty-seventh session of the Commission on Population and Development.

${ }^{54}$ See ' 1994 Cairo Conference prompted 'No Less than a Revolution', Population and Development Commission told' (United Nations - Press Release, Pop 897, 24 March 2004) available at https:// www.un.org/press/en/2004/pop897.doc.htm last accessed 28 May 2018. It seems relevant to recall here that the United Nations have prioritized reproductive rights and, more in general, sexual rights in their agenda as one of the Sustainable Development Goals. Indeed, Goal 3.7 requires that "universal access to sexual and reproductive health-care services, including for family planning, information and education, and the integration of reproductive health into national strategies and programmes" be achieved by 2030 . For further information and for an overview of the Sustainable Development Goals, see the website http://www.undp.org/content/undp/en/home/sustainable-development-goals.html last accessed 28 May 2018. In particular, with reference to Goal 3.7 concerning universal access to sexual and reproductive health-care services, see http://www.undp.org/content/undp/en/home/sustainabledevelopment-goals/goal-3-good-health-and-well-being/targets/. The commitment of the UN has also led to the creation of the UNDP/UNFPA/UNICEF/WHO/World Bank Special Programme of Research, Development and Research Training in Human Reproduction (HRP), a concerted multipartner programme which plays a fundamental role in gathering various types of expertise, as policymakers, scientists, health care providers, clinicians, consumers and community representatives, and in promoting research and dissemination and effective application of its results in order to ensure sexual and reproductive health all over the globe, especially in developing countries. For further information, see the HRP website at http://www.who.int/life-course/partners/human-reproduction/en/ last accessed 28 May 2018.

55 See ' 1994 Cairo Conference prompted 'No Less than a Revolution', Population and Development Commission told' (United Nations - Press Release, Pop 897, 24 March 2004) available at https:// www.un.org/press/en/2004/pop897.doc.htm last accessed 28 May 2018.

56 RODOTÀ, S., Il diritto di avere diritti, cited above n. 9, pp. 86, 87.

57 The efforts for conceptualization of sexual health within the WHO began in 2002 and the working definitions elaborated were published in 2006 and updated in 2010. For an overview of the WHO's Working Definitions on sexual health, see the WHO website at http://www.who.int/ reproductivehealth/topics/sexual_health/sh_definitions/en/ last accessed 28 May 2018.
} 
among the rights "critical for the realization of sexual health". ${ }^{58}$ Both the WHO working definitions and the 1994 Cairo Programme of Action are sources of soft law, thus, they are not binding. What is more, the WHO does not produce such "general normative frameworks of a predominantly philosophical and legal nature" as, for example, the UNESCO.${ }^{59}$ However they are relevant from

58 From a wider perspective, the WHO has developed several initiatives in the framework of reproductive rights. An interesting example is: World Health Organization (WHO), Safe abortion: technical and policy guidance for health systems (World Health Organization, Geneva, 2012), available at http://www.who.int/reproductivehealth/publications/unsafe_abortion/9789241548434/ en/ last accessed 28 May 2018 . For further information, see the website For an overview of the commitment of the WHO and its initiatives and publications, see http://www.who.int/ reproductivehealth/topics/unsafe_abortion/en/ last accessed 28 May 2018. In particular, on unsafe abortion: http://www.who.int/bulletin/volumes/92/3/14-136333/en/ last accessed 28 May 2018. The World Health Organization (WHO), which participates in UN HRC Programme, that was mentioned previously in the footnotes, has adopted several initiatives in the field of reproductive rights, being the WHO meeting on education and treatment in human sexuality of 1974 one of the earliest steps. The WHO's commitment in the field of sexual health has grown through the decades, especially after the 1994 International Conference on Population and Development (ICPD), under the impulse of the acknowledgment of the important health burden that several sexual and reproductive conditions imply. Some reference in this regard can be found in World Health Organization, Sexual health and its linkages to reproductive health: an operational approach, 2017, available at http://apps.who.int/ iris/bitstream/handle/10665/258738/9789241512886-eng.pdf;jsessionid=5AAD8749B3FEAC851C8 74B9E1C6816E1? sequence $=1$ last accessed 28 May 2018. During the 2000s the WHO's commitment in this field has intensified and has led to such outcomes as the WHO's global "Reproductive health strategy to accelerate progress towards the attainment of international development goals and targets", endorsed by the World Health Assembly in 2004, and the Framework for action on developing sexual health programmes, adopted in 2010 . What is more, the WHO has explicitly acknowledged the interrelationship between human rights and the achievement of sexual health on several occasions, one of the most recent examples is the Report of Sexual Health, Human Rights and the Law, issued in 2015, that assessed how States' tackle sexual health and their compliance with human rights standards and obligations. For further analysis and consultation, see: World Health Organization, Reproductive health strategy to accelerate progress towards the attainment of international development goals and targets. Global strategy adopted by the 57th World Health Assembly (World Health Organization, Geneva, 2004) For more information and to access the text of the publication see http://www.who.int/ reproductivehealth/publications/general/RHR_04_8/en/ last accessed 28 May 2018.

World Health Organization, Developing sexual health programmes. A framework for action (World Health Organization, Geneva, 2010). For more information, see http://www.who.int/reproductivehealth/ publications/sexual_health/rhr_hrp_10_22/en/ last accessed 28 May 2018 and for accessing the text of the Framework see http://apps.who.int/iris/bitstream/handle/10665/70501/WHO_RHR_HRP_10.22_ eng.pdf? sequence $=1$ last accessed 28 May 2018. The Framework identified five domains in relation to States' programming for sexual health, namely laws, policies and human rights, education, society and culture, economics, and health. Moreover, "using a multisectoral rights-based approach, it outlines elements of a programme-based response, together with key entry points for the promotion of sexual health by providing information and support for both broad based and targeted community education initiatives". World Health Organization, Sexual health, human rights and the law, June 2015, available at http://apps.who.int/iris/bitstream/handle/10665/175556/9789241564984_eng.pdf?sequence=1 last accessed 28 May 2018.

59 Andorno, R., "Global bioethics at UNESCO: in defence of the Universal Declaration on Bioethics and Human Rights", Journal of Medical Ethics, $n^{\circ} 33(3)$, (March 2007), pp. 150-154, 152; Emanuel, E.j., Grady, C., "Four Paradigms of Clinical Research and Research Oversight", Cambridge Quarterly of Healthcare Ethics, 16, (2006), 82-96, Emanuel, E.j., Wendler, D., Killen, J., Grady, C., "What Makes Clinical Research in Developing Countries Ethical? The Benchmarks of Ethical Research", The Journal of Infectious Diseases, $\mathrm{n}^{\circ}$ 189, (2004), pp. 930-937. Reference is made here specifically to the Universal Declaration on Bioethics and Human Rights, the Universal Declaration

Araucaria. Revista Iberoamericana de Filosofía, Política, Humanidades y Relaciones Internacionales, año 20 , $\mathrm{n}^{\circ} 40$. Segundo semestre de 2018. Pp. 655-732. ISSN 1575-6823 e-ISSN 2340-2199 doi: 10.12795/araucaria.2018.i40.27 
various viewpoints: primarily, because soft law instruments can promote the development of hard international law. Secondly, because these instruments are indicative of an international convergence of views about reproductive rights.

This convergence of views can be found in the jurisprudence of international human rights bodies, whose basic importance was indirectly recalled in the WHO's working definition on "sexual rights" where it stressed that " $[\mathrm{t}]$ he fulfilment of sexual health is tied to the extent to which human rights are respected, protected and fulfilled". In the interpretation of their respective reference instruments, human rights bodies have shown clear understanding of the fact that "[s] exual rights embrace certain human rights that are already recognized in international and regional human rights documents and other consensus documents and in national laws" 60 and their interpretive efforts have concurred to elucidate the content of several reproductive entitlements and the corresponding States' duties. The importance of their interpretive role is all the more clear when it is observed that international hard law provides very little targeted legal bases expressly embodying reproductive rights. In this respect, an interesting exception is Article 14 of the Protocol to the African Charter on Human and Peoples' Rights on the Rights of Women in Africa (the so called "Maputo Protocol"), ${ }^{61}$ that expressly protects "health and reproductive rights". In particular, the provision explicitly embodies the right to fertility, to access to contraception and to receive information about a woman's own sexual health and the sexual health of her partner, especially whether he is affected by sexually transmitted diseases as HIV and the right to self-protection and to protection from sexually transmitted diseases, besides the right to decide the number and spacing of her children and to have family planning education. The provision also defines States duties to provide "adequate, affordable and accessible health services, including information, education and communication programmes", which also have to cover all stages of pregnancy and also the post-natal and breastfeeding phase. Importantly, Article 14. 2 (c) provides States' duty "to protect the reproductive rights of women by authorising medical abortion". The provision has received some criticism as it does not contemplate that access to abortion is ensured in case of socio-economic reasons and on request. This concern seems reasonable, especially when one considers that in Africa

on Human Genome and Human Rights and the International Declaration on Human Genetic Data. These instruments constitute soft law sources but at the same time they have legal nature, as they were adopted in an intergovernmental context, which grants them a peculiar authoritativeness, and they have had the capacity to convey some international convergence of views on their content.

${ }^{60}$ This statement, contained in the WHO working definition of "sexual rights", recalls the nonindependent nature of reproductive rights.

${ }^{61}$ African Union, Protocol to the African Charter on Human and People's Rights on the Rights of Women in Africa (adopted 11 July 2003, entered into force 25 November 2005), available at http:// www.achpr.org/instruments/women-protocol/ last accessed 30 May 2018. 
abortion is still generally seen as a taboo. ${ }^{62}$ However, it may also be argued that the relevance of the provision as a targeted legal basis should not be underestimated, as well as the express prioritization of mother's rights over those of the unborn that it embodies. Moreover, the scope of the provision has to be taken into account in light of the guidance provided by the African Commission on Human and Peoples' Rights (AfCHPR) that, in its General Comment No. 2 on Article 14.1 (a), (b), (c) and (f) and Article 14. 2 (a) and (c) of the Protocol to the African Charter on Human and Peoples' Rights on the Rights of Women in Africa has improved the threshold of protection to be ensured to abortion rights through a combined reading of Article 14(2)(c) of the Maputo Protocol with the right to enjoy the benefits of scientific progress enshrined in Article 15(1)(b) of the International Covenant on Economic, Social and Cultural Rights (ICESCR). In this vein, the AfCHPR has clarified that "[w] omen see themselves denied the right to benefit from the fruits of this progress as soon as they are denied the means to interrupt an unwanted pregnancy safely, using effective modern services". At the universal level, the Committee on the Elimination of All Forms of Discrimination against Women so far has provided a similar but not fully corresponding reading of Article 16(e) of the Convention on the Elimination of All Forms of Discrimination against Women (CEDAW), ${ }^{63}$ which foresees that women and men have equal "rights to decide freely and responsibly on the number and spacing of their children and to have access to the information, education and means to enable them to exercise these rights". In this case, the Committee has not defined States' duties as including the obligation to ensure the right to the benefits of scientific progress but, in its Concluding Observations addressing Costa Rica, it has expressed its concern for the lack of "safest and technologically advanced contraceptive methods" in addition to the lack of safe, legal abortion, and has urged the State to "ensure access to assisted reproductive services," which includes IVF. Moreover, in in its reports, ${ }^{64}$ the Committee has usually relied on Article 16(e) of the CEDAW for urging States to decriminalize abortion. Interestingly enough, in 2016 the Committee has also praised Argentina for passing legislation that regulated and

${ }^{62}$ Indeed, Article 14 of the Maputo Protocol foresees that State shall take all the appropriate measures to ensure abortion in case of sexual assault, rape, incest, when it endangers the mother's mental and physical health and the life of the mother and the child. NABANEH, S., "A purposive interpretation of Article 14(2)(c) of the African Women's Protocol to include abortion on request and for socio-economic reasons", A dissertation submitted in partial fulfilment of the requirements of the degree LLM (Human Rights and Democratisation in Africa).

${ }^{63}$ Convention on the Elimination of All Forms of Discrimination Against Women, cited above n. 5.

64 Two interesting examples are Chile and, in the United Kingdom, Northern Ireland. The Committee addressed the latter quite recently, in early 2018, to ensure access to abortion when it is therapeutic and when the mother's psychical health is endangered. The case of Northern Ireland seems particularly interesting as it is comparable to El Salvador, since both countries provide long-lasting imprisonment, and these measures are likely to amount to torture or inhuman or degrading treatment, besides constituting a gender-based discrimination.

Araucaria. Revista Iberoamericana de Filosofía, Política, Humanidades y Relaciones Internacionales, año 20, $n^{\circ} 40$. Segundo semestre de 2018. Pp. 655-732. ISSN 1575-6823 e-ISSN 2340-2199 doi: 10.12795/araucaria.2018.i40.27 
Human Rights and the European Court of Human Rights

ensured access to all scientific methods of assisted reproductive technology (ART). ${ }^{65}$

The urge for decriminalization of abortion is a common trait of the jurisprudence of also other universal human rights bodies, which shows a generalized prioritization of the mother's rights to life, to physical and mental integrity and to private life over the protection of the unborn at the international level. In this sense, the Committee on the Rights of the Child, in its General comment No. 4 (2003): Adolescent Health and Development in the Context of the Convention on the Rights of the Child, ${ }^{66}$ has stressed that adequate protection has to be ensured under the Convention on the Rights of the Child (CRC) $)^{67}$ in case of early pregnancy, through access to sexual and reproductive health service, including abortion "where it is not against the law". ${ }^{68}$ Furthermore, the Committee has urged States Parties to decriminalize abortion, ${ }^{69}$ in order to "reduce maternal morbidity and mortality in adolescent girls, particularly caused by early pregnancy and unsafe abortion practice". ${ }^{70}$ This reading of States' duties under the CRC is not precluded by the statement contained the Preamble of the Convention, according to which the child "needs special safeguards and care, including appropriate legal protection, before as well as after birth". ${ }^{71}$ Indeed, "it was not [intended] to preclude the possibility

${ }^{65}$ CEDAW Committee, Concluding Observations: Argentina, paras. 4(d), 32, U.N. Doc. CEDAW/C/ARG/CO/7 (2016).

${ }^{66}$ UN Committee on the Rights of the Child (CRC), General comment No. 4 (2003): Adolescent Health and Development in the Context of the Convention on the Rights of the Child, 1 July 2003, CRC/GC/2003/4, available at http://www.refworld.org/docid/4538834f0.html last accessed 28 May 2018, para. 27.

${ }^{67}$ Convention on the Rights of the Child, cited above n. 4.

${ }^{68}$ UN Committee on the Rights of the Child (CRC), General comment No. 4 (2003), para. 27.

${ }^{69}$ For example, see the Concluding Observations adopted by the Committee on the Rights of the Child which urged States to decriminalize abortion, as for example Chile, Nicaragua and, more recently, in 2016, Ireland and to ensure adequate protection to pregnant young girls in need of a therapeutic abortion, as it was the case for Chad and Costa Rica. See: Concluding observations, CRC, Chile, CRC/C/15/Add.173, 03 April 2002; UN Committee on the Rights of the Child (CRC), UN Committee on the Rights of the Child: Concluding Observations, Chile, 23 April 2007, CRC/C/ $\mathrm{CHL} / \mathrm{CO} / 3$; UN Committee on the Rights of the Child (CRC), Consideration of reports submitted by States parties under article 44 of the Convention : Convention on the Rights of the Child : concluding observations : Nicaragua, 20 October 2010, CRC/C/NIC/CO/4; Committee on the Rights of the Child, Concluding Observations on Chad, CRC/C/15/Add.107 (1999); CEDAW/C/DOM/CO/6-7 (2013), para. 37(c); Committee on the Rights of the Child, Concluding Observations on Costa Rica, CRC /C/CRI/CO/4 (2011); UN Committee on the Rights of the Child (CRC), Concluding observations on the combined third and fourth periodic reports of Ireland, 29 January 2016, CRC/C/IRL/CO/3-4. Also see: Committee on Economic, Social and Cultural Rights, Concluding Observations on United Kingdom of Great Britain and Northern Ireland, E/C.12/GBR/CO/5 (2009).

${ }^{70}$ UN Committee on the Rights of the Child (CRC), General comment No. 4 (2003): Adolescent Health and Development in the Context of the Convention on the Rights of the Child, 1 July 2003, CRC/GC/2003/4, para. 27, available at http://www.refworld.org/docid/4538834fo.html last accessed 31 May 2018.

${ }^{71}$ Declaration on the Rights of the Child, Proclaimed by General Assembly Resolution 1386(XIV) of 20 November 1959. This was the basis of the basis of the Convention of the Rights of the Child, Preamble. https://www.unicef.org/malaysia/1959-Declaration-of-the-Rights-of-the-Child.pdf last 
of an abortion", as clarified during the travaux préparatoires. ${ }^{72}$ Furthermore, this interpretation is consistent with Article 24 of the $\mathrm{CRC}^{73}$ that "ensure[s] appropriate pre-natal and post-natal health care for mothers" $;{ }^{74}$ this is all the more true when one considers that the content of this provision was reversed during the travaux préparatoires, as the original wording prioritized the protection of, the unborn. ${ }^{75}$

In a similar fashion, the Human Rights Committee (HRC), the monitoring body of the International Covenant on Civil and Political Rights (ICCPR), ${ }^{76}$ in its General Comment No. 28 on "The Equality of Rights between Men and Women", 77 has clarified that States are bound "to ensure that [women] do not

accessed 29 May 2018. For wider analysis, see: Joseph, R., Human Rights and the Unborn Child, Leiden, Boston, Martinus Nijhoff Publisher, 2009. pp. $5 \mathrm{ff}$, who otherwise holds that although this statement is not binding however, since it is contained in the Preamble, it influences the interpretation of the whole CRC according to the interpretive rules enshrined in Article 31(2) of the Vienna Convention on the Law of the Treaties. See: Hulme, M. H., "Preambles in treat interpretation", University of Pennsylvania Law Review, n 164, (2016), pp. 1281-1343.

${ }^{72}$ Consideration 1980 Working Group, E/CN.4/L. 1542, PP. 2-5. During the travaux préparatoires, it was also clarified that this statement contained in the Preamble of the CRC, which echoes the Declaration of the Rights of the Child 1959 and was suggested by the Holy See, did not prejudice the interpretation of Article 1 of the CRC, on the definition of childhood, either. In particular, Article 1 defines a child as "every human being below the age of eighteen years", a notion that is extended to prenatal life.

${ }^{73}$ Convention on the Rights of the Child, adopted and opened for signature, ratification and accession by General Assembly resolution 44/25 of 20 November 1989, entry into force 2 September 1990, available at http://www.ohchr.org/en/professionalinterest/pages/crc.aspx last accessed 29 May 2018.

${ }_{74}$ Meza-Lopehandía G., M., "El aborto en el derecho internacional de los derechos humanos", Biblioteca Nacional del Congreso Nacional del Chile, Departamento de Estudios, Estensión y Publicaciones, 7 de noviembre de 2016, p. 7. In this regard, see UN Committee on the Rights of the Child (CRC), General comment No. 7 (2005): Implementing Child Rights in Early Childhood, 20 September 2006, CRC/C/GC/7/Rev.1, available at http://www.refworld.org/docid/460bc5a62.html last accessed 28 May 2018. The General Comment, at para. 27(2), has urged States Parties to protect mothers' health by ensuring "[p]riority [...] to the provision of appropriate prenatal and post-natal health care for mothers and infants".

75 Indeed, the 1978 Draft of the Convention that, at the then Article IV that provided that Sates shall provide special care to both the child and the mother, including of prenatal and postnatal nature. Finally, the provision modified, especially in consideration of the fact that many negotiating States allowed abortion in their legal order, as the representative of Austria underlined. For wider analysis of the travaux préparatoires of the Convention on the Rights of the Child, see Detrick, S., Doek, J. E., Cantwell, N., The United Nations Convention on the Rights of the Child: A Guide to the “Travaux Préparatoires" (Martinus Nijhoff Publishers, Dordrecht, Boston, London, 1992) and MezaLopehandía G., M., "El aborto en el derecho internacional de los derechos humanos", cited above n. 73, p. 8. In this regard, also see Paulk, L. B., "Embryonic Personhood: Implications for Assisted Reproductive Technology in International Human Rights Law", American University Journal of Gender Social Policy and Law, $\mathrm{n}^{\circ}$ 22(4), 2014, pp. 781-823, in particular where the Author stresses that "[c]learly, the drafters did not want the Preamble's language to be interpreted as granting rights to the unborn", at p. 799.

${ }^{76}$ International Covenant on Civil and Political Rights, cited above n. 3.

${ }^{77}$ UN Human Rights Committee (HRC), CCPR General Comment No. 28: Article 3 (The Equality of Rights Between Men and Women), 29 March 2000, CCPR/C/21/Rev.1/Add.10, https://adsdatabase. ohchr.org/IssueLibrary/HRC\%20General\%20Comment\%2028.pdf last accessed 1 June 2018, paras. 10 and 11 , and 20, respectively on safe abortion and doctors' duty to report cases of women who have undergone abortion.

Araucaria. Revista Iberoamericana de Filosofía, Política, Humanidades y Relaciones Internacionales, año $20, \mathrm{n}^{\circ} 40$. Segundo semestre de 2018. Pp. 655-732. ISSN 1575-6823 e-ISSN 2340-2199 doi: 10.12795/araucaria.2018.i40.27 
have to undergo life-threatening clandestine abortions"78 in relation to the protection of the right to life, enshrined in Article 6 of the Covenant. The fact that the protection of the unborn does not fall within the scope of this provision could already be inferred from the travaux préparatoires of the ICCPR: an amendment that was aimed at incorporating the specification that life begins at conception in Article 6 of the Covenant, which provides that "[e]very human being has the inherent right to life", was rejected. ${ }^{79}$ Furthermore, in its periodical reports, the HRC has exhorted States to decriminalize abortion and ensure that women can access it in three cases, namely the existence of a risk for their life, rape and incest; the first ground prioritizes the mother's life over the life of the unborn, whilst the other grounds prioritize mother's mental health, dignity and autonomy. ${ }^{80}$ Moreover, the HRC has deemed that State's interference due to the imposition of doctors' duty to report cases of women who have undergone abortion amounts to a breach of the prohibition of torture or cruel, inhuman or degrading treatment under Article 7 of the Covenant. ${ }^{81}$ The Committee had the chance to elucidated further the scope of this provision in relation to reproductive rights when, in the K.L. v. Peru case, ${ }^{82}$ it considered the individual communication of a young mother who was pregnant of an anencephalic baby. In this case, the HRC found that the denial of therapeutic abortion amounted to a breach of Article 7 of the ICCPR, since "[ $\mathrm{t}]$ he omission on the part of the State in not enabling the author to benefit from a therapeutic abortion was, in the Committee's view, the cause of the suffering she experienced" 83 and "the right set out in article 7 of the Covenant relates not only to physical pain but also to mental suffering, and that the protection is particularly important in the case of minors", which made unnecessary to make a finding on Article 6

${ }^{78}$ Ibid, para. 10.

79 Meza-Lopehandía G., M., "El aborto en el derecho internacional de los derechos humanos", cited above n. 73. The rejection of the amendment intended to introduce the specification "from conception" also seems to refute the view that the unborn would be a human rights bearer according to the statement, contained in the Preamble, that "rights of all members of the human family ... [which] derive from the inherent dignity of the human person". Again, it would not seem convincing the view that would conclude for the inclusion of prenatal life within the scope of Article 6 of the ICCPR in light of the statement embodied in paragraph 5 thereof, which provides that "[s]entence of death [...] shall not be carried out on pregnant women". This provision, indeed, is to be related to the prohibition to carry out sentences of death on minor subjects. This reading of the scope of the right to life under the ICCPR seems to be consistent with the subsequent interpretation of Article 6 of the Covenant offered by the Human Rights Committee (HRC). See: Joseph, R., Human Rights and the Unborn Child, cited above n. 70, pp. 135 ff. See also: Yoshihara, S., "Book review of "Human Rights and the Unborn Child by Rita Joseph"”, available at http://c-fam.org/wp-content/uploads/Q11.3_Joseph_ revYoshihara.pdf last visited 28 May 2018.

${ }^{80}$ Meza-Lopehandía G., M., "El aborto en el derecho internacional de los derechos humanos", cited above n. 73, p. 6.

${ }^{81}$ K.L. v. Peru, Communication No. 1153/2003, UN Doc. CCPR/C/85/D/1153/2003 (2005).

${ }^{82} \mathrm{Ibid}$. The HRC has also clarified that reproductive rights include the right to decide the number and timing of children, that was considered especially to the forced sterilization cases, and which reflects the generalized view enshrined in the above-mentioned soft law instruments.

${ }^{83}$ Ibid., para. 6.3.

Araucaria. Revista Iberoamericana de Filosofia, Politica, Humanidades y Relaciones Internacionales, año 20, $\mathrm{n}^{\circ} 40$. Segundo semestre de 2018. Pp. 655-732. ISSN 1575-6823 e-ISSN 2340-2199 doi: 10.12795/araucaria.2018.i40.27 
of the ICCPR. ${ }^{84}$ The refusal to terminate the pregnancy was unjustified, thus the Committee also found a breach of the right to private life protected under Article 17 of the Covenant. ${ }^{85}$ The HRC has extended its urge also to ARTs and, its Concluding Observations about Costa Rica, ${ }^{86}$ has called on the State to "do all it can to pursue its stated intention to eliminate the ban on in vitro fertilization and to prevent excessive restrictions from being placed on the exercise of the rights set out in articles 17 and 23 of the Covenant by persons who wish to avail themselves of that technology" 87

It is interesting and important to stress that the prioritization of the mother's rights could already be found in the travaux préparatoires of the Universal Declaration on Human Rights (UDHR), that is considered the archetype of $\mathrm{UN}$ human rights instruments and which, moreover, is a basic reference in international human rights law despite it is a resolution and not a treaty. Indeed, during the preparatory works, the rejection of an amendment that required to specify that life begins at conception indicated that where Article 1 of the UDHR provides that "[a]11 human beings are born free and equal in dignity and rights", it does not mean that the unborn has the rights enshrined in the Declaration. $^{88}$

Conclusively, it seems of fundamental importance to recall that recently General Comment No. $22(2016)^{89}$ on the right to sexual and reproductive health

${ }^{84}$ The HRC had clarified this issue in Human Rights Committee, General Comment No. 20: Prohibition of torture and other cruel, inhuman or degrading treatment or punishment (art. 7), 10 March 1992 (HRI/GEN/1/Rev.7, paras. 2 and 5), available at http://hrlibrary.umn.edu/gencomm/ hrcom20.htm last accessed 28 May 2018.

${ }^{85}$ In this regard, see para. 6.4 of the Communication of the HRC. Moreover, the HRC also found a breach of Article 2 of the ICCPR, which protects the right to an adequate remedy, and of Article 24 , pursuant to which States are bound to ensure special protection to the rights of the minors. In this regard, see paras. 6.6 and 6.5 of the decision of the HRC.

${ }^{86}$ Human Rights Committee, Concluding Observations: Costa Rica, paras. 19-20, U.N. Doc. CCPR/C/CRI/CO/6 (2016).

${ }^{87}$ Ibid., para. 20.

${ }^{88}$ The UDHR foresees that "everyone has the right to life" at Article 3, but the hub of the discussion at the intersection between the protection of prenatal life and recognition of reproductive rights has to be sought in the above-mentioned Article 1 that, as mentioned, enshrines a quite evocative expression where it says that "[a]11 human beings are born free and equal in dignity and rights". Reference to birth is evocative in many respects: it may be intended as a reference to the jusnaturalist conception that human rights are inborn, which raised some criticism from the then soviet countries, or it may be read in light of specific national perspective, as it was the case for Syria, which intended the wording of the provision as a form of protection from slavery from birth. As said above, some pressures were made for introducing an amendment that extended the protection of life from conception, but it was rejected. Again, for instance, France explicitly clarified that the statement contained in Article 1 of the UDHR was intended to protect rights "from the moment of birth." In this respect, it seems at odds with the views expressed in scholarship, which argued that UN General Assembly Third Committee invited the negotiating States not to use their national laws to water down the content of the UDHR, a statement that this scholarship suggested to intend also with regard to the right to life and the possible impact of abortion laws on the understanding of its scope. See: Joseph, R., Human Rights and the Unborn Child, cited above n. 70, pp. 135 ff. See also: Yoshihara, S., "Book review of "Human Rights and the Unborn Child by Rita Joseph"', cited above n. 70.

${ }^{89}$ UN Committee on Economic, Social and Cultural Rights, General comment No. 22 (2016) on the 
(article 12 of the International Covenant on Economic, Social and Cultural Rights) of the Committee on Economic, Social and Cultural Rights, the monitoring body of the ICESCR, has defined reproductive rights as part of the core of "the right of everyone to the highest attainable physical and mental health" ${ }^{\circ 0}$ and its enjoyment. In particular, it has clarified that " $[\mathrm{t}]$ he right to sexual and reproductive health is an integral part of the right to health enshrined in article 12 of the International Covenant on Economic, Social and Cultural Rights". ${ }^{91}$ What is more, the General Comment has incorporated "technological advances and innovations" within the standard of "quality", when dealing with the 4 A-Scheme that characterizes the Committee's approach to the elucidation of several entitlements protected under the Covenant, including health. In particular, General Comment No. 22 (2016) clarifies that "[t]he failure or refusal to incorporate technological advances and innovations in the provision of sexual and reproductive health services, such as medication for abortion, assisted reproductive technologies and advances in the treatment of HIV and AIDS, jeopardizes the quality of care". ${ }^{2}$

Despite the pluralism that characterizes the scientific and the domestic legal debate at the intersection between the protection of the unborn and reproductive rights, at the international level a shared, core conception can be found as to the scope of abortion and reproductive rights and, generally, the prevalence of the protection of the mother. Also access to ARTs and, in particular, to IVF has achieved generalized understanding and acceptance in this framework. Interestingly, the path to affirm the enjoyment of reproductive rights and the related technologies under the right to enjoy the benefits of scientific progress has been paved at the regional level. That being said, the question now is to assess whether also the ECtHR and the IACtHR have adopted the same approach and, if so, to which extent.

\section{Reproductive challenges in the jurisprudence of the ECtHR}

The European Court of Human Rights has developed an advanced approach in the field of biolaw which is unique in the international legal scenario and is representative of the nature of the ECHR as a "living instrument", 93 capable of

right to sexual and reproductive health (article 12 of the International Covenant on Economic, Social and Cultural Rights), 2 May 2016, E/C.12/GC/22, available at http://docstore.ohchr.org/SelfServices/ FilesHandler.ashx?enc=4s1Q6QSmIBEDzFEovLCuW1a0Szab0oXTdImnsJZZVQfQejF41Tob4CvIj eTiAP6sGFQktiae1vlbbOAekmaOwDOWsUe7N8TLm\%2BP3HJPzxjHySkUoHMavD\%2Fpyfcp3 Ylzg accessed 28 May 2018.

90 Ibid., para 11

91 Ibid., para. 1

92 Ibid., para. 21

93 The conception of the ECHR as a living instrument was first introduced by the ECtHR in the Tyrer v. United Kingdom, (Appl. No. 5856/72) Judgment of 25 April 1978, Series A no. 26, para. 31. For further examples, see: Goodwin v United Kingdom (Appl. No. 17488/90) Judgment of 27 
keeping the pace with the challenges posed by evolution in all fields including, of course, scientific progress. In this regard, the fruitful outcomes of the Court's jurisprudence are clearly helped by the normative framework of the Council of Europe in the field of biolaw, ${ }^{94}$ that represents the most advanced experience at both the universal and regional level, and encompasses such areas as euthanasia, genetics and biomedical research.

Reproductive rights were not neglected. The importance of their protection was clarified by the Council of Europe Commissioner for Human Rights Nils Muižnieks when he said that “[w]omen's sexual and reproductive health and rights are human rights [and] States must resolutely commit to advancing gender equality in this crucial sphere of life. They have the duty to provide all women with accessible, affordable, good quality sexual and reproductive health care and services". This view, that is developed from a gender perspective, underlies the "Issue Paper on Women's sexual and reproductive health and rights" which clearly affirms States' duty to ensure the enjoyment of reproductive rights and access to abortion. This view is in line with the core conception that can be found at the international level. When dealing with the human embryo and the foetus, the focus of the COE was principally set on the protection in the field of biomedical research, in order to define its possibilities but also its limitations and, in this context, some consideration was given to ARTs and especially to IVF. In this regard, Recommendation 1046 (1986) of the Parliamentary Assembly of the Council of Europe on the use of human embryos and foetuses for diagnostic, therapeutic, scientific, industrial and commercial purposes, ${ }^{95}$ called on the Governments of Member States "to forbid any creation of human embryos by fertilisation in vitro for the purposes of research during their

March 1996, para. 74; Demir and Baykara v Turkey (Appl. No. 34503/97) Judgment of 12 November 2008, paras. 68 and 146. Among the decisions related to prenatal life and reproductive rights, a remarkable example is Vo. v. France, no. 53924/00, § 35, Judgment of 8 July 2004, para. 82 and the Dissenting Opinion of Judge Mularoni, Joined by Judge Strážnická. Letsas, G., "The ECHR as a living instrument: Its meaning and legitimacy", in Constituting Europe: The European Court of Human Rights in a National, European and Global Context, Føllesdal, A., Peters, B., Ulfstein, G., Cambridge, New York, Melbourne, Madrid, Cape Town, Singapore, São Paulo, Delhi, Mexico City, Cambridge University Press, 2010, pp. 106-141.

${ }^{94}$ It is undeniable that the experience of the Council of Europe, from a comprehensive viewpoint, is more advanced when compared to other regional realities and it also stands out at the universal level: it goes without saying that the UNESCO has been capable of adopting very important soft law tools, namely "its" Declarations in the field of bioethics, which have legal nature and are significant for the understanding of the common international views they enshrine.

95 Council of Europe, Parliamentary Assembly, Recommendation 1046 (1986) of the Parliamentary Assembly of the Council of Europe on the use of human embryos and foetuses for diagnostic, therapeutic, scientific, industrial and commercial purposes, Assembly debate on 19 and 24 September 1986 (13th and 18th Sittings) (see Doc. 5615Doc. 5615, report of the Legal Affairs Committee, Doc. 5628, opinion of the Committee on Science and Technology, and Doc. 5635, opinion of the Social and Health Affairs Committee). Text adopted by the Assembly on 24 September 1986 (18th Sitting), available online at http://assembly.coe.int/nw/xml/XRef/Xref-XML2HTML-en. asp?fileid=15080\&lang=en accessed 2 June 2018.

Araucaria. Revista Iberoamericana de Filosofía, Política, Humanidades y Relaciones Internacionales, año 20, $\mathrm{n}^{\circ} 40$. Segundo semestre de 2018. Pp. 655-732. ISSN 1575-6823 e-ISSN 2340-2199 doi: 10.12795/araucaria.2018.i40.27 
life or after death" ${ }^{96}$ Some more elucidation is offered by Recommendation 1100 (1989) of the Parliamentary Assembly of the Council of Europe on the use of human embryos and foetuses in scientific research ${ }^{97}$ where it calls on States "to take steps to guarantee that society is informed simply, accurately and sufficiently of activities involving techniques of assisted fertilisation and related techniques, and more specifically of fertilisation in vitro and the use of human gametes, embryos or foetuses for scientific investigation or other purposes". ${ }^{98}$ Moreover, the Recommendation provides some clarification in relation to the definition of the status of the embryo, where it states that the human embryo, from the stage of the zygote to that of the foetus, "displays also a progressive differentiation as an organism and none the less maintains a continuous biological and genetic identity". 99

Besides the relevant soft law tools, the most interesting references for our purposes can be found in the Convention on Human Rights and Biomedicine (the so called "Oviedo Convention") and its Additional Protocols, which is unique in the landscape of international law, as it is the only existing hard law instrument in the field of biolaw. Considering the pluralism that characterizes this area, this achievement is a milestone, also because it enshrines a humanrights based approach. The Oviedo Convention does not expressly address the issue of the beginning of life or reproductive rights. Nonetheless, at Article 14 it specifies that "techniques of medically assisted procreation shall not be allowed for the purpose of choosing a future child's sex, except where serious hereditary sex-related disease is to be avoided" 100 and, at Article 18, it clarifies

${ }^{96}$ Ibid., see paras. 3 and 14.1.3. It seems interesting to stress here also that, at para. 14.1.7, it has called on States "to facilitate and encourage the creation of national multidisciplinary committees or commissions on artificial human reproduction involving scientific activities concerning genetic material, human embryos and foetuses - to guide and counsel the medical and scientific authorities, to follow and control the application of such techniques and to authorise specific projects in the absence of concrete legislation or regulation".

${ }^{97}$ Council of Europe, Parliamentary Assembly, Recommendation n. 1100 (1989) "Use of human embryos and foetuses in scientific research", Assembly debate on 2 February 1989 (24th Sitting) (see Doc. 5943, report of the Committee on Science and Technology, Rapporteur: Mr Palacios; Doc. 5989, opinion of the Social, Health and Family Affairs Committee, Rapporteur: Mrs Hubinek ; andDoc. 5996, report of the Legal Affairs Committee, Rapporteur: Mr Elmquist). Text adopted by the Assembly on 2 February 1989 (24th Sitting), para. 7, available at http://assembly.coe.int/nw/xml/xref/ xref-xml2html-en.asp?fileid=15134\&lang=en last accessed 2 June 2018.

98 Ibid., para. 9.2.2.

${ }_{99}$ Council of Europe, Resolution 1352 (2003) of the Parliamentary Assembly of the Council of Europe on human stem cell research, Origin - Assembly debate on 2 October 2003 (33rd Sitting) (see Doc. 9902report of the Committee on Culture, Science and Education, rapporteur: Mr Wodarg; and Doc. 9942opinion of the Social, Health and Family Affairs Committee, rapporteur: Mr Høie). Text adopted by the Assembly on 2 October 2003 (33rd Sitting) that, at para. 10, has held that "[ $\mathrm{t}]$ he destruction of human beings for research purposes is against the right to life of all humans and against the moral ban on any instrumentalisation of humans", available at http://www.assembly.coe.int/nw/ $\mathrm{xml} / \mathrm{XRef} / \mathrm{Xref}-\mathrm{XML} 2 \mathrm{HTML}-\mathrm{EN}$.asp?fileid=17158\&lang=en last accessed 20 June 2018.

${ }^{100}$ Council of Europe, Convention for the protection of Human Rights and Dignity of the Human Being with regard to the Application of Biology and Medicine: Convention on Human Rights and 
that research on human embryo "may be performed only for health purposes or for scientific research linked to health purposes, and subject to appropriate genetic counselling", and that adequate protection has to be ensured where law allows research on embryos in vitro. ${ }^{101}$ The ECtHR is not competent to directly apply the Oviedo Convention and its Additional Protocols in its case law; nevertheless, these instruments can provide a helpful support to the interpretation of the ECHR, in line with Article 31(3)(c).

In this respect, the jurisprudence of the Court offers an interesting example of this use of the Oviedo Convention's system in relation to its attempt to define whether the protection of prenatal life falls within the scope of Article 2 of the ECHR, which provides that "[e]veryone as the right to life", in the case of Vo v. France. ${ }^{102}$ This judgment is a milestone in the Court's jurisprudence on prenatal life and concerns the unwanted loss of the foetus due to medical negligence. When assessing whether the unborn was included within the notion of "everyone" under Article 2 of the ECHR, the Court underlined that "[ $\mathrm{t}] \mathrm{he}$ potentiality of that being and its capacity to become a person" [...] require protection in the name of human dignity [which is ensured in some cases under civil law at the domestic level] without making it a "person" with the "right to life" for the purposes of Article 2". ${ }^{103}$ In this regard, as a support to its reading, the ECtHR recalled that "[t]he Oviedo Convention on Human Rights and Biomedicine $[\ldots]$ is careful not to give a definition of the term "everyone", and that $[\mathrm{t}]$ he same is true of the Additional Protocol on the Prohibition of Cloning Human Beings and the Additional Protocol on Biomedical Research, which do not define the concept of "human being"". ${ }^{104}$ The reasons of this approach are set out in the "explanatory report [to the Oviedo Convention which] indicates that, in the absence of a unanimous agreement on the definition, the member States decided to allow domestic law to provide clarification for the purposes of the application of that Convention". ${ }^{105}$ This statement recalls a basic feature of the Court's approach, that is the doctrine of the margin of appreciation. ${ }^{106}$

Biomedicine (adopted in Oviedo, 4 April 1997, entered into force 1 December 1999) ETS No. 164, P, available at https://rm.coe.int/168007cf98 accessed 20 June 2018.

101 Ibid., Article 12.

102 European Court of Human Rights (Grand Chamber), Vo v France, Judgment of 8 July 2004, Appl. No. 53924/00, Reports of Judgments and Decisions 2004-VIII, available at https:/hudoc.echr. coe.int/eng\# $\{\% 22$ fulltext $\% 22:[\% 22 \mathrm{vo} \% 22], \% 22$ documentcollectionid $\% 22:[\% 22$ GRANDCHAMB ER\%22,\%22CHAMBER\%22],\%22itemid\%22:[\%22001-61887\%22]\} accessed 20 July 2018.

103 Ibid. 84

104 Ibid.

105 Ibid.

106 The doctrine of the margin of appreciation was conceived in the Tyrer case in order to preserve regional pluralism and to leave appropriate discretional room to States Parties when implementing their obligations under the ECHR. Of course, the margin of appreciation is not unlimited, but its extent descends from the scope of application and protection of the entitlements specifically at stake time after time. Moreover, as the ECtHR had the chance to clarify in its case law, in particular, in the Belgian Linguistic case, "the machinery of protection established by the Convention is subsidiary to the

Araucaria. Revista Iberoamericana de Filosofía, Política, Humanidades y Relaciones Internacionales, año 20, ${ }^{\circ} 40$. Segundo semestre de 2018. Pp. 655-732. ISSN 1575-6823 e-ISSN 2340-2199 doi: 10.12795/araucaria.2018.i40.27 
According to this doctrine, the lack of regional consensus on a given question increases States' margin of appreciation whilst its existence narrows States' discretionality. It goes without saying that, usually, in the biolegal field and even more in the definition of the beginning of life, States enjoy a wide margin of appreciation, due to the intense pluralism in this field. National ethics may be quite different in this respect. This is why the Court, in the Vo judgment, recognizing that "[a]t European level [...] there is no consensus on the nature and status of the embryo and/or foetus", ${ }^{107}$ "[was] convinced that it is neither desirable, nor even possible as matters stand, to answer in the abstract the question whether the unborn child is a person for the purposes of Article 2 of the Convention"108 and that "[a]t best, it may be regarded as common ground between States that the embryo/foetus belongs to the human race". ${ }^{109}$ Indeed, the question of the beginning of life is deferred to States' margin of appreciation notwithstanding the Convention [is] a "living instrument which must be interpreted in the light of present-day conditions" 110 and despite the embryo and the foetus "are beginning to receive some protection in the light of scientific progress and the potential consequences of research into genetic engineering, medically assisted procreation or embryo experimentation". ${ }^{111}$ In the $V o$ case, the ECtHR has adopted an approach of self-restraint ${ }^{112}$ that hugely

national systems safeguarding human rights"; see: European Court of Human Rights (Court Plenary), Case "Relating to Certain Aspects of The Laws on the Use of Languages in Education in Belgium" v. Belgium, Judgment (Merit) of 23 July 1968, Appl. No. 1474/62 1677/62 1691/62, 1769/63, 1994/63, 2126/64, available at https://hudoc.echr.coe.int/eng\# \{\%22fulltext $\% 22:[\% 22$ RELATING\%20TO\%20 CERTAIN\%20ASPECTS\%20OF\%20THE\%20LAWS\%20ON\%20THE\%20USE\%20OF\%20 LANGUAGES $\% 20$ IN $\% 22$ ], $\% 22$ documentcollectionid2\%22:[\%22GRANDCHAMBER $\% 22, \% 22 \mathrm{C}$ HAMBER\%22],\%22itemid\%22:[\%22001-57525\%22]\} last accessed 20 June 2018.

See Council of Europe, "The Margin of Appreciation", available at https://www.coe.int/t/dghl/ cooperation/lisbonnetwork/themis/echr/paper2_en.asp last accessed 20 June 2018. See: Barbarosa Delgado, F. R., "El margen nacional de apreciación en e Derecho Internacional de los Derechos Humanos: entre el Estado de Derecho y la sociedad democrática", México, Universidad Nacional Autónoma de México. Instituto de Investigaciones Jurídicas, (2012), pp. 51-82, available at http:// bibliohistorico.juridicas.unam.mx/libros/7/3160/7.pdf last accessed 20 June 2018. The ECHR defines minimum common standards of protection, that can be increased - but not diminished - at the domestic level. In practice, the scrutiny of the margin of appreciation is carried out by assessing, primarily, that a legitimate aim is pursued by the State through the measure challenged; then, the then, the Court verifies whether the standard of proportionality was respected. In this regard, see: GARCÍA SAN JOSÉ, D.I., International Bio Law. An International Overview of Developments in Human Embryo Research and Experimentation, cited above n. 10, pp. $171 \mathrm{ff}$.

${ }^{107}$ Vo v. France, cited above n. 101, para. 84

${ }^{108}$ Ibid., para. 85 .

${ }^{109}$ Ibid., para. 84.

${ }^{110}$ Ibid., para. 82.

${ }^{111}$ Ibid., para. 84.

112 The jurisprudence of the ECtHR follows the two lines of judicial activism and of judicial self-restraint, that were effectively described as two sides of the same coin or as a pendulum, in the Court's approach to human rights protection. GARCÍA SAN JOSÉ, D.I., International Bio Law. An International Overview of Developments in Human Embryo Research and Experimentation, cited above n. 10, pp. 172.

Regional pluralism requires judicial restraint, while the Court can be more purposeful in the

Araucaria. Revista Iberoamericana de Filosofia, Política, Humanidades y Relaciones Internacionales, año 20, ${ }^{\circ} 40$. Segundo semestre de 2018. Pp. 655-732. ISSN 1575-6823 e-ISSN 2340-2199 doi: 10.12795/araucaria.2018.i40.27 
characterizes its jurisprudence in the field of the definition of the protection of the unborn and reproductive rights. Thirteen years later, the Court recalled again the conception of the human embryo's "potentiality of becoming a person" when, in the Parrillo v. Italy case, ${ }^{113}$ it was called on to assess the generalized ban posed by Italian Law No. 40/2004 on the donation to scientific research of the cryopreserved embryos obtained from in vitro fertilization for originally reproductive purposes. The Court recognized that "the embryos contain the genetic material of the [mother] and accordingly represent a constituent part of [her] genetic material and biological identity" 114 and therefore considered that the applicant's "choice regarding the fate of her embryos concern[ed] an intimate aspect of her personal life and accordingly relate[d] to her right to self-determination [under] Article 8 of the Convention, from the standpoint of the right to respect for private life". ${ }^{115}$ Notwithstanding this, and despite "the sensitive and controversial question of when human life begins as Article 2 of the Convention is not in issue in the [...] case", ${ }^{116}$ the Court acknowledged that "the "protection of the embryo's potential for life" may be linked to the aim of protecting morals and the rights and freedoms of others, in the terms in which this concept is meant by the Government". ${ }^{117}$ Then, despite it did not mean to express "any assessment [...] as to whether the word "others" extends to human embryos" ${ }^{118}$ the Court found a violation of Article 8 of the ECHR since "the ban

definition of the protection to be granted through judicial activism when a regional consensus exists. In particular, various factors can enhance States' margin of appreciation, and moral issues are one of them. See: Council of Europe, "The Margin of Appreciation", cited above n. 105. In this respect, emblematic decisions of the application of the margin of appreciation with regard to moral questions were adopted by the ECtHR in the judgments issued in the cases: European Court of Human Rights, Muller and Others v. Switzerland, Judgment of 24 May 1988, Appl. No. 10737/84, A133, available at https://hudoc.echr.coe.int/eng\# \{\%22fulltext $\% 22:[\% 22$ muller\%22],\%22documentcollectionid $2 \%$ 22:[\%22GRANDCHAMBER\%22,\%22CHAMBER\%22],\%22itemid\%22:[\%22001-57487\%22]\} last accessed 20 June 2018. European Court of Human Rights, Dickson v. the United Kingdom, Judgment of 4 December 2007, 44362/04, Reports of Judgments and Decisions 2007-V, available at https://hudoc.echr.coe.int/eng\#\{\%22fulltext\%22:[\%22dickson\%22],\%22documentcollectionid2 $\% 22:[\% 22$ GRANDCHAMBER $\% 22, \% 22$ CHAMBER $\% 22], \% 22$ itemid $\% 22:[\% 22001-83788 \% 22]$ \} last accessed 20 June 2018; European Court of Human Rights, Handyside v. the United Kingdom, Judgment of 4 November 1976, Appl. No. 5493/72, A24, available at https://hudoc.echr.coe.int/eng\#\{ $\% 22$ fulltext $\% 22:[\% 22$ handyside $\% 22], \% 22$ documentcollectionid $2 \% 22:[\% 22$ GRANDCHAMBER $\%$ 22,\%22CHAMBER\%22],\%22itemid\%22:[\%22001-57499\%22]\} last accessed 20 June 2018.

${ }_{113}$ European Court of Human Rights (Grand Chamber), Parrillo v. Italy, Judgment of 27 August 2015, Appl. No. 46470/11, Reports of Judgments and Decisions 2015, available at https://hudoc. echr.coe.int/eng\# \{\%22fulltext $\% 22:[\% 22$ parrillo $\% 22], \% 22$ documentcollectionid $2 \% 22:[\% 22 \mathrm{GRA}$ NDCHAMBER $\% 22, \% 22$ CHAMBER\%22],\%22itemid\%22:[\%22001-157263\%22]\} last accessed 20 June 2018. See Poli, L., "La sentenza Parrillo c. Italia e quello che la Corte (non) dice sullo status dell'embrione", Quaderni di SIDIblog, (2015), pp. 511-516 and "Bioethics, human rights and their interplay in the legal reasoning of ECtHR's case law on artificial reproductive technologies", Federalismi.it, Focus on Human Rights, $n^{\circ}$ 1, (2017).

114 Ibid., para. 158.

115 Ibid., para. 159.

${ }^{116}$ Ibid., para., para 215.

${ }^{117}$ Ibid., para. 167.

118 Ibid.

Araucaria. Revista Iberoamericana de Filosofía, Política, Humanidades y Relaciones Internacionales, año 20, $\mathrm{n}^{\circ} 40$. Segundo semestre de 2018. Pp. 655-732. ISSN 1575-6823 e-ISSN 2340-2199 doi: 10.12795/araucaria.2018.i40.27 
was 'necessary in a democratic society' to protect the rights and freedoms of others within the meaning of Article 8(2) of the ECHR". ${ }^{119}$ In this regard, Italy had not overstepped the - wide ${ }^{120}$ - margin of appreciation granted under these circumstances ${ }^{121}$ and, again, regional consensus lacked on the issue "of the donation of embryos not destined for implantation [which] clearly raises "delicate moral and ethical questions". ${ }^{122}$ Beyond the pluralism of views, however, the Court could exclude that human embryos can be reduced to "possessions" within the meaning of [Article 1 of Protocol No.1 to the Convention on the protection of property]". ${ }^{123}$

However, on some occasions the ECtHR has adopted an approach of selfrestraint even in cases where a clear regional consensus existed, and under some circumstances States have been allowed a wide margin of appreciation due to the moral vision that was rooted in the country and in the society. The reason for this has to be sought in the role of the Court to provide guidance and harmonization between forty-seven States, whose legal, ethical and social landscape can be very different. The ECtHR, thus, aims to provide some common minimum standards of protection of human rights and, when pursuing this objective, it also tries to avoid a clash with States, as the system is founded on national consent. Therefore, it has to preserved, and wise use of the doctrine of the margin of appreciation is a helpful means. ${ }^{124}$

Abortion is a remarkable example, and it is interesting to consider how the Court usually exercises its scrutiny in this field and provides protection under the procedural limb of private life. In the early Nineties, when the ECtHR was called on to take its decision in the case of Open Door and Dublin Well Woman v. Ireland judgment, ${ }^{125}$ the Court "acknowledge[d] that the national authorities

119 Ibid., para. 197.

${ }^{120} \mathrm{Ibid}$, para. 174. In particular, the Court allowed a wide margin of appreciation because "the right invoked by the applicant to donate embryos to scientific research is not one of the core rights attracting the protection of Article 8 of the Convention as it does not concern a particularly important aspect of the applicant's existence and identity". In fact, the importance of the right for the individuals is one of the factors that narrow State's margin of appreciation, as well as the lack of regional consensus. The other factors are represented by the teleological interpretation of the ECHR and the model of democratic society considered under the Convention. See: García San José, D.I., International Bio Law. An International Overview of Developments in Human Embryo Research and Experimentation, cited above n. 10, pp. 177.

${ }^{121}$ Parrillo v. Italy, cited above n. 112, para. 197.

122 Parrillo v. Italy, cited above n. 112, para. 176.

123 Parrillo v. Italy, cited above n. 112, para. 215.

124 García San José, D.I., International Bio Law. An International Overview of Developments in Human Embryo Research and Experimentation, cited above n. 10, pp. 188 ff.; Council of Europe, "The Margin of Appreciation", cited above n. 105.

${ }^{125}$ European Court of Human Rights, Open Door and Dublin Well Woman v. Ireland, Judgment of 23 September 1992, Appl. Nn. 14234/88 14235/88, 64/1991/316/387-388, available at https://hudoc. echr.coe.int/eng\#\{\%22fulltext $\% 22:[\% 22$ open $\% 20$ doors $\% 22], \% 22$ documentcollectionid2\%22:[\%22 GRANDCHAMBER \%22,\%22CHAMBER \%22],\%22itemid\%22:[\%22001-57789\%22]\} last visited 11 July 2018. LAWSON, R., "The Irish abortion cases: European limits to national sovereignty?", cited above n. 42 . 
enjoy a wide margin of appreciation in matters of morals, particularly in an area such as the present which touches on matters of belief concerning the nature of human life". ${ }^{126}$ With regard to Ireland, ${ }^{127}$ the legal, ethical and social implications of abortion are particularly sensitive: in fact, Article 40(3)(3) of the Irish Constitution equalizes the right to life of the unborn and the right to life of the mother and, what is more, abortion is prohibited under criminal law by section 58 of the Offences Against the Person Act 1861, which provides as penalty "penal servitude for life". The only exceptional case in which abortion is allowed is the existence of a risk for the mother's life. Nearly twenty years after the Open Door judgment, in the $A, B, C$ v. Ireland case, ${ }^{128}$ the Court reiterated its view. In particular, it clarified that it "[did] not consider that the prohibition in Ireland of abortion for health and well-being reasons, based as it is on the profound moral views of the Irish people as to the nature of life [... and as to the consequent protection to be accorded to the right to life of the unborn, exceeds the margin of appreciation accorded in that respect to the Irish State". ${ }^{129}$ In fact, "[s]ince the rights claimed on behalf of the foetus and those of the mother are inextricably interconnected [...] the margin of appreciation accorded to a State's protection of the unborn necessarily translates into a margin of appreciation for that State as to how it balances the conflicting rights of the mother". ${ }^{130}$ Under similar circumstances, the regional "consensus cannot be a decisive factor in the Court's examination of whether the impugned prohibition on abortion in Ireland for health and well-being reasons struck a fair balance between the conflicting rights and interests, notwithstanding an evolutive interpretation of the Convention". ${ }^{131}$ It can be argued that the reason for this approach is that if the ECtHR assumed the task of striking the balance between the conflicting right to life of the unborn and the right to life of the mother, it would have to define the question of the beginning of life. In this regard, the view set out in the $V o$ case is well-settled, and the Court expressly recalled it in the $A, B, C$ v. Ireland judgment when it held that "the question of when the right to life begins came within the States' margin of appreciation because there was no European consensus on the scientific and legal definition of the beginning of life, so that it was impossible to answer the question whether the unborn was

${ }^{126}$ Open Door and Dublin Well Woman v. Ireland, cited above n. 124, para. 68.

${ }^{127}$ Lawson, R., “The Irish abortion cases: European limits to national sovereignty?", cited above n. 42 .

128 European Court of Human Rights Court (Grand Chamber), A, B and $C$ v. Ireland, Judgment (Merits and Just Satisfaction) of 16 December 2010, Appl. No. 25579/05, Reports of Judgments and Decisions 2010, available at https://hudoc.echr.coe.int/eng\#\{\%22fulltext $\% 22:[\% 22 \mathrm{~A}, \% 20 \mathrm{~B} \% 22]$ ,\%22documentcollectionid 2\%22:[\%22GRANDCHAMBER \%22,\%22CHAMBER \%22], \%22item id\%22:[\%22001-102332\%22]\} last accessed 20 June 2018.

129 Ibid., para. 241.

${ }_{130}$ Ibid., para. 237.

${ }^{131} A, B$ and $C$ v. Ireland, cited above n. 127, para. 237.

Araucaria. Revista Iberoamericana de Filosofía, Política, Humanidades y Relaciones Internacionales, año 20, $\mathrm{n}^{\circ} 40$. Segundo semestre de 2018. Pp. 655-732. ISSN 1575-6823 e-ISSN 2340-2199 doi: 10.12795/araucaria.2018.i40.27 
a person to be protected for the purposes of Article 2". ${ }^{132}$ Nevertheless, when assessing the alleged violation of applicant C's right to respect for her private life under Article 8 of the ECHR under the procedural limb, the Court found that a violation had occurred, basically because Ireland had failed to implement the Constitutional ban on abortion through legislation "and [because] more particularly [...] the lack of effective and accessible procedures to establish a right to an abortion under that provision [had generated an uncertainty resulting] in a striking discordance between the theoretical right to a lawful abortion in Ireland on the ground of a relevant risk to a woman's life and the reality of its practical implementation". ${ }^{133}$ This view is settled in the Court's case law and another example is offered by Tysiac $v$. Poland case, ${ }^{134}$ where the ECtHR clarified that "once the legislature decides to allow abortion, it must not structure its legal framework in a way which would limit real possibilities to obtain it." ${ }^{135}$ In the same vein, in the R.R. v. Poland judgment, ${ }^{136}$ the ECtHR specified that "[w] hile a broad margin of appreciation is accorded to the State as regards the circumstances in which an abortion will be permitted in a State, once that decision is taken the legal framework devised for this purpose should be "shaped in a coherent manner which allows the different legitimate interests involved to be taken into account adequately and in accordance with the obligations deriving from the Convention". ${ }^{137}$ Therefore, although the Court has not come to affirm that States have a conventional a duty to ensure abortion, however, it has recognized that States are under some procedural obligations, in relation to the right to respect for private life, to ensure access to abortion if legislation allows it.

It is interesting to consider the Court's approach to ARTs and, in particular to IVF, and how the doctrine of the margin of appreciation interrelates with scientific progress. A relevant but also quite disputed example is offered by the case of S.H. and Others v. Austria, ${ }^{138}$ where the Grand Chamber held that

132 Ibid.

133 Ibid., para. 264.

134 European Court of Human Rights, Tysiac v. Poland, Judgment of 20 March 2007, Appl. No. 5410/03, Reports of Judgments and Decisions 2007-I, para. 116 available at https://hudoc.echr.coe.int/ eng\#\{\%22itemid\%22:[\%22001-79812\%22]\} last visited 12 July 2018.

135 Ibid., para. 116.

136 European Court of Human Rights, R.R. v. Poland, Judgment of 26 May 2011, Appl. No. $27617 / 04$,

Reports of Judgments and Decisions 2011 (extracts), available at https://hudoc.echr.coe.int/eng\#\{ $\% 22$ fulltext $\% 22:[\% 22$ R.R. $\% 22], \% 22$ documentcollectionid $\% 22:[\% 22$ GRANDCHAMBER $\% 22, \%$ 22CHAMBER\%22],\%22itemid\%22:[\%22001-104911\%22]\} last accessed 21 June 2018.

137 Ibid., para. 187.

138 European Court of Human Rights (Grand Chamber), S.H. and Others v. Austria, Judgment of 03 November 2011, Appl. No. 57813/00,

Reports of Judgments and Decisions 2011, available at https://hudoc.echr.coe.int/eng\#\{\%22fulltex t\%22:[\%22s.h.\%22],\%22documentcollectionid2\%22:[\%22GRANDCHAMBER\%22,\%22CHAMBE R\%22],\%22itemid\%22:[\%22001-107325\%22]\} last visited 21 June 2018. See TIMMER, A., "S.H. and Others v Austria: margin of appreciation and IVF", Strasbourg Observers, available at https:// 
the "emerging consensus [about sperm and ova donation for the purposes of in vitro fertilization] is not, however, based on settled and long-standing principles established in the law of the member States but rather reflects a stage of development within a particularly dynamic field of law and does not decisively narrow the margin of appreciation of the State". ${ }^{139}$ The words of the Court raise some perplexity. The reasoning here sounds quite at odds with the Court's usual and settled view as the ECtHR does not neither highlight the lack of consensus, nor excludes that settled consensus is a decisive factor in light of prevalent moral reasons or due to the specific balance to be stricken between conflicting interests; furthermore, of course, the approach that emerges is far from proactive. The contradiction did not go unnoticed even within the Court itself and Judges Tulkens, Hivelä, Lazarova Trajkovska and Tsotsoria, in their Dissenting Opinion, stressed that "[t]he Court thus takes the unprecedented step of conferring a new dimension on the European consensus and applies a particularly low threshold to it, thus potentially extending the States' margin of appreciation beyond limits". ${ }^{140}$ However, this is not the only statement in the judgment that raises some perplexity. The Court has observed that "there is no prohibition under Austrian law on going abroad to seek treatment of infertility that uses assisted procreation techniques not allowed in Austria and that in the event of a successful treatment the Civil Code contains clear rules on paternity and maternity that respect the wishes of the parents". ${ }^{141}$ Arguably, this statement appears at odds with the - praiseworthy - purpose to protect women, especially the most socially and economically vulnerable, from the exploitation and the humiliation to which ova donation might expose them, which Austria included among the reasons for the blanket ban contained in its legislation. ${ }^{142}$ It seems hard not to argue that the statement of the Court may cause some discriminatory impact on women's health. In other words, mainly if not exclusively wealthy couples are likely to afford the costs related to crossborder healthcare, with a consequence that sounds more like "reproductive tourism". ${ }^{143}$ Access to cross-border healthcare was a basic point also in the Court's jurisprudence on the "Irish cases" on abortion, ${ }^{144}$ where it said that

strasbourgobservers.com/2011/11/09/s-h-and-others-v-austria-margin-of-appreciation-and-ivf/ last accessed 18 July 2018.

139 Ibid., para. 96.

${ }^{140} \mathrm{Ibid}$., Joint Dissenting Opinion of Judges Tulkens, Hivelä, Lazarova Trajkovska and Tsotsoria, para. 8 .

${ }^{141}$ Ibid., para. 114.

${ }^{142}$ Ibid., para 66.

${ }^{143}$ Farnós Amorós, E., “¿Debe permitirse la gestación por sustitución en España? Estado de la cuestión y algunas reflexiones", in De la solidaridad al mercado: el cuerpo humano y el comercio biotecnológico, Casado, M., (ed.), Barcelona, Universitat de Barcelona, Edicions de la Universitat de Barcelona, 2017, pp. 195-234, 200.

${ }^{144}$ See LAWSON, R., "The Irish abortion cases: European limits to national sovereignty?", cited above n. 42 .

Araucaria. Revista Iberoamericana de Filosofía, Política, Humanidades y Relaciones Internacionales, año 20, $\mathrm{n}^{\circ} 40$ Segundo semestre de 2018. Pp. 655-732. ISSN 1575-6823 e-ISSN 2340-2199 doi: 10.12795/araucaria.2018.i40.27 
"[h] aving regard to the right to travel abroad lawfully for an abortion with access to appropriate information and medical care in Ireland, the Court [did not consider] that the prohibition in Ireland of abortion for health and wellbeing reasons, based as it is on the profound moral views of the Irish people as to the nature of life $[. .$.$] and as to the consequent protection to be accorded to$ the right to life of the unborn, exceeds the margin of appreciation". Indeed, the "impugned prohibition [...] struck a fair balance between [the conflicting right] to respect for [the applicants'] private life and the rights invoked on behalf of the unborn". ${ }^{145}$

Thus, the situation is quite different. On the one hand, the Court has never affirmed a right to abortion under the substantial limb of Article 8 of the ECHR because, despite the existing regional consensus, the peculiar domestic moral vision, that is deeply rooted, requires to reconcile the conflicting rights at stake in a specific, consistent way. What is more, the affirmation under the ECHR of the right to abortion under the substantial limb of the right to private life, as stressed above, would require to define the issue of the beginning of life. And, in that respect, the lack of consensus does not allow it. On the other hand, in the $S . H$. ruling, ${ }^{146}$ although the Court had recognized "the right of a couple to conceive a child and to make use of medically assisted procreation for that purpose is also protected by Article 8, as such a choice is an expression of private and family life", it concluded that no violation had occurred because of the "particularly low threshold" applied to the emerging regional consensus, with its consequences on the width of State's margin of appreciation. The view of the Court in the S.H. ruling is clearly at odds with its usual approach to scientific progress and reproduction, which is consistent in the other rulings. In the Evans v. the United Kingdom case, ${ }^{147}$ in which the ECtHR was called to decide on the withdrawal of parents' consent as to the implantation of the embryos created in vitro, the Court affirmed that the right to respect for the decision to become a parent in the genetic sense is protected under Article 8 of the ECHR. ${ }^{148}$ Nevertheless, in the case, the Court acknowledged that "it cannot

\footnotetext{
${ }^{145} A, B$ and $C$ v. Ireland, cited above n. 127, para. 241.

${ }_{146}$ S.H. and Others v. Austria, cited above n. 137, para. 82.

147 European Court of Human Rights (Grand Chamber), Evans v. the United Kingdom, Judgment of 10 April 2007, Appl. No. 6339/05, Reports of Judgments and Decisions 2007-I, available at https:// hudoc.echr.coe.int/eng\#\{\%22fulltext $\% 22:[\% 22$ evans $\% 22], \% 22$ documentcollectionid $\% 22:[\% 22 \mathrm{G}$ RANDCHAMBER\%22,\%22CHAMBER\%22],\%22itemid\%22:[\%22001-80046\%22]\} last accessed 21 June 2018.

${ }_{148}$ Ibid., para. 71. Few months later, in the Dickson v. the United Kingdom case, the Court reaffirmed the right to become genetic parents when it held that "Article 8 is applicable to the applicants' complaints in that the refusal of artificial insemination facilities concerned their private and family lives, which notions incorporate the right to respect for their decision to become genetic parents" (Para. 66). The case concerned reproductive rights of the prisoners and of the detainees and conjugal visits. In this regard, "[t]he Court note[d], as to the European consensus argument, that the Chamber established that more than half of the Contracting States allow for conjugal visits for prisoners (subject to a variety of different restrictions), a measure which could be seen as obviating
} 
be said that there is any consensus as to the stage in IVF treatment when the gamete providers' consent becomes irrevocable"149 and consequently "since the use of IVF treatment gives rise to sensitive moral and ethical issues against a background of fast-moving medical and scientific developments, and since the questions raised by the case touch on areas where there is no clear common ground amongst the member States, the Court considers that the margin of appreciation to be afforded to the respondent State must be a wide one". ${ }^{150}$ The embryos were destined to destruction but, once more, the Court recalled the $V o$ judgment to reiterate that "the embryos [...] do not have a right to life within the meaning of Article 2 of the Convention". ${ }^{151}$ The Evans judgment is in line with the Court's application of the doctrine of the margin of appreciation and with its approach of self-restraint in front of ethical pluralism and strong domestic morality.

It is interesting to notice that the Court has so far tended to recognize and protect the rights related to prenatal and preimplantation diagnosis: this jurisprudence is limited to only two cases, but the approach of the Court is promising. The R.R. v. Poland judgment, ${ }^{152}$ the Court found that the denied access to amniocentesis for the mother whose baby was born severely disabled amounted to a violation of Article 3 and Article 8 of the ECHR. In particular, the Strasbourg Court held that the right to private life encompasses access to prenatal genetic testing that, in the case, was the precondition for the applicant to get the necessary information to know whether she met the requirements set for lawful abortion under Polish law. In this regard, the Court clarified that " $[\mathrm{t}]$ he right of access to [the information on a person's health] falling within the ambit of the notion of private life can be said to comprise $[. .$.$] a right to obtain available information on$

the need for the authorities to provide additional facilities for artificial insemination. However, while the Court has expressed its approval for the evolution in several European countries towards conjugal visits, it has not yet interpreted the Convention as requiring Contracting States to make provision for such visits [...]. Accordingly, this is an area in which the Contracting States could enjoy a wide margin of appreciation in determining the steps to be taken to ensure compliance with the Convention with due regard to the needs and resources of the community and of individuals" (Paras. 81). However, the Court also found "that the Policy as structured effectively excluded any real weighing of the competing individual and public interests, and prevented the required assessment of the proportionality of a restriction, in any individual case" (Para. 82) and, therefore, it "[found] that the absence of [required proportionality assessment in an individual case] as regards a matter of significant importance for the applicants [...] must be seen as falling outside any acceptable margin of appreciation so that a fair balance was not struck between the competing public and private interests involved. There has, accordingly, been a violation of Article 8 of the Convention." (Para. 84). See European Court of Human Rights (Grand Chamber), Dickson v. the United Kingdom, No. 44362/04, Judgment of 4 December 2007, Reports of Judgments and Decisions 2007-V, available at https:/hudoc.echr.coe. int/eng\# \{\%22fulltext $\% 22:[\% 22$ dickson $\% 22], \% 22$ documentcollectionid $\% 22:[\% 22$ GRANDCHAM BER\%22,\%22CHAMBER\%22],\%22itemid\%22:[\%22001-83788\%22]\} last accessed 21 June 2018.

149 Evans v. the United Kingdom, cited above n. 146, para. 79.

${ }^{150}$ Evans v. the United Kingdom, cited above n. 146, para. 81.

${ }^{151}$ Evans v. the United Kingdom, cited above n. 146, para. 56.

152 R.R. v. Poland, cited above n. 135. 
one's condition [and] during pregnancy the foetus' condition and health constitute an element of the pregnant woman's health". Then, the Court went on and further held that "the effective exercise of [the] right (of access to information about her or his health) is often decisive for the possibility of exercising personal autonomy, also covered by Article 8 of the Convention, by deciding, on the basis of such information, on the future course of events relevant for the individual's quality of life (e.g. by refusing consent to medical treatment or by requesting a given form of treatment)." ${ }^{153}$ In the judgment, the Court relied on the doctrine of the margin of appreciation, not only when recalling the considerations made in the $V o$ judgment to stress that the unborn does not have the right to life, but also with reference to the procedural guarantees to be ensure under the procedural limb of private life, when it held that "[if] the State, acting within the limits of the margin of appreciation, [...] adopts [...] [a] domestic law [that] allows for abortion in cases of foetal malformation, there must be an adequate legal and procedural framework to guarantee that relevant, full and reliable information on the foetus' health is available to pregnant women". ${ }^{154}$ One year after the R.R. ruling, in the Costa and Pavan $v$. Italy judgment, ${ }^{155}$ the Court basically relied on proportionality when it held that the applicants, who were both healthy carrier of a genetic disease, had a right to access to prenatal genetic diagnosis under Article 8 of the ECHR in the context of in vitro fertilization. The Court acknowledged that "the question of access to PGD raises sensitive moral and ethical questions" but it also recognized that "the solutions reached by the legislature are not beyond the scrutiny of the Court", ${ }^{156}$ in so far as its task was "to verify the proportionality of the measure in question in the light of the fact that termination of pregnancy on medical grounds is an option for the applicants". ${ }^{157}$ The Second Section adopted a pervasive view that, nevertheless, does not clash with the fact that the "Court's task is not to substitute itself for the competent national authorities in determining the most appropriate policy for regulating matters of assisted procreation, observing in particular that the use of in vitro fertilisation techniques raised sensitive moral and ethical questions [in an area that was constantly evolving]",

${ }^{153}$ R.R. v. Poland, cited above n. 135, para. 197.

154 R.R. v. Poland, cited above n. 135, para. 200.

155 European Court of Human Rights, Costa and Pavan v. Italy, Judgment of 28 August 2012, Appl. No. 54270/10, available at https://hudoc.echr.coe.int/eng\# $\{\% 22$ fulltext $\% 22:[\% 22 \operatorname{costa} \% 2$ 2], $\% 22$ documentcollectionid2\%22:[\%22GRANDCHAMBER $\% 22, \% 22$ CHAMBER $\% 22], \% 22$ it emid\%22:[\%22001-112993\%22]\} last accessed 21 June 2018. See DI STEFANO, A., "Bio-ethics under Human Rights Scrutiny: Toward a Right to Pre-implantation Genetic Testing under the ECHR?", Strasbourg Observers, 20 September 2012, available at https://strasbourgobservers.com/ category/cases/costa-and-pavan-v-italy/ last accessed 18 July 2018, and "Tutela del corpo femminile e diritti riproduttivi: biopotere e biodiritto nella vicenda italiana in tema di diagnosi preimpianto", Osservatorio di Diritti Umani, La Comunità Internazionale, Fascicolo n 4, (2013), pp. 745-772.

${ }^{156}$ Ibid., para. 69.

157 Ibid., para. 70.

Araucaria. Revista Iberoamericana de Filosofia, Política, Humanidades y Relaciones Internacionales, año 20, ${ }^{\circ} 40$. Segundo semestre de 2018. Pp. 655-732. ISSN 1575-6823 e-ISSN 2340-2199 doi: 10.12795/araucaria.2018.i40.27 
as stressed in the S.H. ruling. ${ }^{158}$ In the Costa and Pavan case, the ECtHR found that Italian legislation pursued a legitimate aim under Article 8(2) of the ECHR, namely "protecting morals and the rights and freedoms of others". ${ }^{159}$ The Court carried out a careful scrutiny of proportionality that nevertheless included considerations connected to the doctrine of the margin of appreciation when the Court recalled that, out of the thirty-two States whose legislation was analysed, only Italy, Switzerland and Austria did not allow pre-implantation diagnosis. In light of the test of proportionality, the Court found that " $\mathrm{t}] \mathrm{h}$ he consequences of [Italian] legislation for the right to respect for the applicants' private and family life are self-evident. In order to protect their right to have a child unaffected by the disease of which they are healthy carriers, the only possibility available to them is to start a pregnancy by natural means and then terminate it if the prenatal test shows that the foetus is unhealthy". ${ }^{160}$ Abortion is evidently a more grievous alternative if compared to PGD, when the sufficient reasons for State's interference are considered according to the second level of the proportionality test. ${ }^{161}$ In this regard, the "standard of the sufficient reasons" requires that the State adopt the less grievous mean for pursuing the legitimate aim. What is more, the view of the Court offered important clarification also in relation to possible concerns of eugenics, which the Italian State had expressed when it held that the applicants were alleging a violation of their right to have an healthy child. ${ }^{162}$ However, the Court dismissed such allegation, clarifying that "the right relied on by the applicants is confined to the possibility of using ART and subsequently PGD for the purposes of conceiving a child unaffected by cystic fibrosis" ${ }^{163}$ since "PGD cannot exclude other factors capable of compromising the future child's health". ${ }^{164}$ The Court recalled Article 12 of the Oviedo Convention, which allows predictive genetic tests and the corresponding Paragraph 83 of the Explanatory Report as relevant international law but, then, it did not incorporated these references in its legal reasoning. Possibly, incorporation as a support to the interpretation of the ECHR may have enhanced the Court's arguments, with special reference to Paragraph 83 where it clarifies that "Article 12 as such does not imply any limitation of the right to carry out diagnostic interventions at the embryonic stage to find out whether an embryo carries hereditary traits that will lead to serious diseases in the future child". In fact, although Italy has signed but not yet ratified

${ }_{158}$ S.H. and Others v. Austria, cited above n. 137, para. 92.

${ }^{159}$ Costa and Pavan v. Italy, cited above n. 154, para. 59.

160 Costa and Pavan v. Italy, cited above n. 154, para. 65.

161 The first level of the proportionality test focuses on whether State's interference pursued a legitimate aim and, in this regard, the standard to meet is less strict, since "relevant" and not "sufficient" reasons for the interference are required to justify it. See GARCÍA SAN JOSÉ, D.I., International Bio Law. An International Overview of Developments in Human Embryo Research and Experimentation, cited above n. 10, pp. $175 \mathrm{ff}$.

${ }_{162}$ Costa and Pavan v. Italy, cited above n. 154, para. 44; 53.

${ }^{163}$ Costa and Pavan v. Italy, cited above n. 154, para. 53.

${ }^{164}$ Costa and Pavan v. Italy, cited above n. 154, para. 54

Araucaria. Revista Iberoamericana de Filosofía, Política, Humanidades y Relaciones Internacionales, año 20, $\mathrm{n}^{\circ} 40$. Segundo semestre de 2018. Pp. 655-732. ISSN 1575-6823 e-ISSN 2340-2199 doi: 10.12795/araucaria.2018.i40.27 
the Oviedo Convention, the State is under an obligation not to defeat the object and the purpose of the treaty pursuant to Article 18 of the VCLT. What is more, some further support to accessibility to IVF might have been interestingly advanced by recalling Article 15 of the ICESCR, which protects the right to benefit from scientific progress, this time in line with Article 31(3)(c) of the VCLT, as Italy is Party to the Covenant. Viability of a similar approach was suggested by the Judges Tulkens, Hirvelä, Lazarova Trajkovska and Tsotsoria who, in their Dissenting Opinion in the S.H. case have recalled Article 12 and Article 15 of the International Covenant on Economic, Social and Cultural Rights (ICESCR), on the right to health and on the right to science to stress the need to ensure access to IVF, since it is not "a question of choice between different techniques but, more fundamentally, a restriction on access to heterologous in vitro fertilisation constituting denial of access to available treatment". ${ }^{165}$ However, so far, the Court has not adopted this kind of approach in its case law, showing a tendency to be more self-referential than other human rights bodies. Therefore, so far, the steps ahead towards the definition of individual rights and corresponding States' obligations in relation to access to scientific progress in the reproductive field have basically been the result of the use of its usual decisional paths, that means relying on the doctrine of the margin of appreciation and the test of proportionality. In this regard, thus, we may conclude that the common core of the conception of the reproductive rights to some extent can be found in the jurisprudence of Strasbourg Court. Whilst, on the one hand, the Court's selfrestraint in the field of abortion rights may be plausible, however it is to wish that the "backward step" 166 taken in the S.H. v. Austria judgment, with that disputable reading of regional consensus and its possible distorted effects in practice, remains an isolated case.

\section{The evolutionary approach to reproductive rights in the jurisprudence of the IACtHR}

On the other side of the Atlantic Ocean, the role of the Inter-American Court of Human Rights has been of basic importance for the promotion of reproductive rights and their protection. The regional framework that the Court has to deal with is quite different from the European one: on the one hand, national realities are more homogeneous, as the twenty-five countries that are Parties to the Convention - only twenty-one of which have accepted the competence of the Court - are all Latin American States. In practice, these States have a common

165 S.H. and Others v. Austria, cited above n. 137, Joint Dissenting Opinion of Judges Tulkens, Hivelä, Lazarova Trajkovska and Tsotsoria, para. 9.

166 Ibid., para. 8.

Araucaria. Revista Iberoamericana de Filosofia, Politica, Humanidades y Relaciones Internacionales, año 20, ${ }^{\circ} 40$. Segundo semestre de 2018. Pp. 655-732. ISSN 1575-6823 e-ISSN 2340-2199 doi: 10.12795/araucaria.2018.i40.27 
cultural core and they have been through a process of democratization during the Nineties in light of which they now can be defined as "new democracies". ${ }^{167}$ On the other hand, the regional framework on reproductive rights is more delicate and sometimes controversial than the European scenario. Latin America is currently undergoing an important process in relation to abortion rights: in 2017, Chile has legalized abortion when mother's life is in danger, when the pregnancy is the result of rape and when the foetus is not viable; moreover, it is very recent news that the Argentinian Chamber of Deputies has passed a bill that provides legalization of elective abortion within the fourteenth week of pregnancy, and even beyond this term in case of danger to mother's life, rape and in cases the foetus suffers severe conditions incompatible with life outside the womb. Brazil, otherwise, is facing an opposite situation, as some restrictive trends seem to be progressively gaining ground in the country, where the Supreme Court is assessing the possibility to criminalize abortion, which now is allowed in the country in case the mother's life endangered, when the pregnancy is the result of rape and when the foetus is affected anencephaly. States' approach is usually restrictive: Dominican Republic, El Salvador and Nicaragua are three emblematic examples, as in the first two countries abortion is banned except in case the mother's life is endangered, whilst in Nicaragua the ban is total and allows no exceptions. ${ }^{168}$ Otherwise, ARTs, including IVF have found generalized acceptance in Latin America, with the only exception of Costa Rica: it is emblematic that in 1990, the Latin American Registry of Assisted Reproduction (RLA) was established as the first multinational and regional registry of assisted reproductive technology. ${ }^{169}$

The Inter-American Court of Human Rights has not had as many chances as the Strasbourg Court to deal with reproductive rights; nevertheless, its approach stands out for being proactive and for having effectively promoted their protection in the region. The relevant decisions of the Court came more than thirty years after the Inter-American Commission of Human Rights (IACHR) was called on to take a decision in the field of abortion rights for the first time in the Inter-American human rights system in the early Eighties, in the Baby Boy v. the United States case. ${ }^{170}$ Called on to consider the issue

${ }^{167}$ Groppi, T., Lecis Cocco-Ortu, A. M., "Le citazioni reciproche tra la Corte Europea e la Corte Interamericana dei Diritti dell'Uomo: dall'influenza al dialogo", Federalismi.it, n. 19, (2013), pp. 1-38, 9 .

${ }^{168}$ For an overview about Latin American landscape, see Corrêa, S., De La Dehesa, R., Parker, R. G., "Sexuality and Politics: Regional Dialogues from the Global South, Volume 1", Rio de Janeiro, Sexuality Policy Watch, 2015.

169 Zegers-Hochschild, F., Enrique Schwarze, J., Crosby, J. A., Musri, C., Urbina, R. T., “Assisted reproductive techniques in Latin America: The Latin American Registry, 2014", JBRA Assisted Reproduction, No. 21(3), (2017), pp. 164-175, 164.

${ }^{170}$ Inter-American Commission on Human Rights, Resolution No. 23/81 of 16 October 1981, Case 2141 ("Baby Boy v. the United States of America"), available at http://bcn.cl/1v5kf last accessed 21 June 2018.

Araucaria. Revista Iberoamericana de Filosofía, Política, Humanidades y Relaciones Internacionales, año 20, $n^{\circ} 40$. Segundo semestre de 2018. Pp. 655-732. ISSN 1575-6823 e-ISSN 2340-2199 doi: 10.12795/araucaria.2018.i40.27 
of the beginning of life under circumstances that concerned a belated elective abortion, ${ }^{171}$ the Commission relied on the American Declaration of the Rights and Duties of Men (ADRDM), ${ }^{172}$ as the United States have signed but not ratified the ACHR. However, some reference was also made to the Convention, since the parties had specifically vested the Commission with assessing whether it could be considered as a support to the interpretation of the State's duties under the Declaration. The interpretive task in which the Commission engaged was delicate, as emerges when the content of the relevant provisions is taken into consideration: Article 1 of the ADRDM provides that "[e]very human being has the right to life" and Article 4(1) of the ACHR enshrines a highly disputed provision, where it foresees that "[e]very person has the right to have his life respected. This right shall be protected [...], in general, ${ }^{173}$ from the moment of conception". The Commission based its interpretation on the travaux préparatoires of both instruments: ${ }^{174}$ with regard to the ADRDM, the formulation of the provision contained in the draft submitted to the Juridical Committee included an explicit reference to "the right to life [that] extends to the right to life from the moment of conception". This reference was then erased from the text, and instead of "every person" now the provision refers to "every human being". This was considered as the clear intention to exclude prenatal life from the scope of the provision, as the view among the negotiating States was divergent. The debate during the travaux préparatoires of the ACHR evolved in a similar fashion, as States still had different views and, above all, different legislations on abortion. ${ }^{175}$ However, the reference to the "conception" was kept in the text, and the locution "in general" was incorporated for the purpose of reconciliating the distinct opinions. ${ }^{176}$ Consistently with this perspective, the

${ }^{171}$ The Baby Boy case originated in the Roe $v$. Wade case, a milestone in the domestic American jurisprudence, as it represented the culmination of a line of jurisprudence that considered that women's right to abortion was encompassed in the right to define their own private sphere. U.S. Supreme Court, 22 January 1973, No. 70-18, Roe v. Wade, 410 U.S. 113 (1973). See Rodotà, S., Trattato di Biodiritto, ll Governo del Corpo, Milano, Giuffré Editore, p. 890.

172 Organisation of the American States, Inter-American Commission on Human Rights (IACHR), American Declaration of the Rights and Duties of Man, 2 May 1948, available at http://www.oas.org/ en/iachr/mandate/Basics/declaration.asp last accessed 22 June 2018.

173 Emphasis added.

${ }^{174}$ In scholarship, the interpretive criterion adopted by the Commission was criticized, as Article 32 of the VCLT includes the preparatory works among the supplementary means of interpretation of treaties. See Díaz, Á. P., "Estatus del no nacido en la Convención Americana: un ejercicio de interpretación", Revista Ius et Praxis, n 1, Año 18, (2012), pp. 75 ff.

175 During the negotiations, Brazil, soon joined by the United States, had held that no reference to conception should be included in the provision, while Venezuela was one of the greatest supporters of the protection of life since conception and the need to incorporate this statement, unconditionally and without any further locution as "in general" in the text of the Convention. See DÍAZ, Á. P., "Estatus del no nacido en la Convención Americana: un ejercicio de interpretación", cited above n. 173, pp. $61-112$.

176 In scholarship, it was stressed that the final formulation of Article 4(1) of the ACHR is a "solution of principles, not of concessions among American States". Nevertheless, the debate is still "alive and kicking": it still was when Mexico, almost thirty years later, made an interpretive 
Commission came to the conclusion that the ADRDM had not incorporated the notion that the right to life exists from the moment of conception, as "the conference faced this question but chose not to adopt the language that would clearly have stated this principle". ${ }^{177}$ Thus, the IACHR found no violation of Article I of the ADRDM ${ }^{178}$ and, as to Article 4(1) of the ACHR, the Commission held that "the legal implications of the clause "in general, from the moment of conception" are substantially different from the shorter clause "from the moment of conception". ${ }^{179}$ Nevertheless, this did not affect the case, as the United States had not ratified the Convention and "it would be impossible to impose upon [them] an international obligation based upon a treaty that [they] had not duly accepted or ratified" ${ }^{180}$ The view expressed by the Commission is clear: the unborn does not have the right to life.

When the issue was brought before the Court, the results achieved were different from several viewpoints: the IACtHR did not affirm that the unborn has the right to life. Nonetheless, it recognized that some protection that is due, dependent on the progressive conception of its development that the Court adopts; therefore, the balance has to be stricken under the specific circumstances between the rights of the unborn and the rights of the mother. These outcomes were not achieved all at once in the case law of the Court, but followed some interesting steps: previously, on some occasions, the Court had addressed the unborn using the words "children", ${ }^{181}$ "minors", ${ }_{182}$ "babies", as it was the case for its judgments Miguel Castro-Castro Prison v. Peru, ${ }^{183}$ Goiburú et al. v. Paraguay ${ }^{184}$ and Gómez-Paquiyauri Brothers v. Peru ${ }^{185}$ often recognizing a compensation for the consequences affecting the unborn and that were caused by the physical suffering, the distress or the ailment suffered by the mothers under the peculiar circumstances of each case. The case of Sawhoyamaxa

reservation clarifying that "legislation to protect life "from the moment of conception," [is a] matter [that] falls within the domain reserved to the States". In scholarship it was stressed that this statement should be considered not an interpretive declaration but a reservation, since it changes the scope of the duty assumed by Mexico. In this regard, ibid., pp. 17, 83, 84 .

177 Baby Boy v. the United States of America, cited above n. 170, para. 19(h).

178 Ibid., para. 1, among the resolutions of the IACHR.

${ }^{179}$ Ibid., para. 30.

${ }^{180} \mathrm{Ibid}$., para. 31. In fact, the United States are under an obligation not to defeat the object and the purpose of the treaty pursuant to Article 18 of the VCLT, but of course no use of the ACHR as a support to the interpretation of the ACHR could be made pursuant to Article 31(3)(c).

${ }_{181}$ Inter-American Court of Human Rights, Case of the Miguel Castro-Castro Prison v. Peru, Judgment of 25 November 2006, Merits, Reparations, and Costs, Series C No. 160. In the judgment the Court recognized them compensation for their non-pecuniary damages, such as "feelings of anguish, despair, and fear for the lives of their children (at para. 292 of the judgment).

${ }_{182}$ Inter-American Court of Human Rights, Case of Goiburú et al. v. Paraguay, Judgment of 22 September 2006, Merits, Reparations and Costs, Series C No. 153, at 91, 104, para. 160(b)(iii).

${ }_{183}$ Case of the Miguel Castro-Castro Prison v. Peru, cited above n. 180.

${ }_{184}$ Case of Goiburú et al. v. Paraguay, cited above n. 181, para 91.

${ }^{185}$ Inter-American Court of Human Rights, Case of Gómez-Paquiyauri Brothers v. Peru, Judgment of 8 July 2004, Merits, Reparations, and Costs, Series C No. 110, 1 71. See paras. 67(x) and 216.

Araucaria. Revista Iberoamericana de Filosofía, Política, Humanidades y Relaciones Internacionales, año 20, $\mathrm{n}^{\circ} 40$. Segundo semestre de 2018. Pp. 655-732. ISSN 1575-6823 e-ISSN 2340-2199 doi: 10.12795/araucaria.2018.i40.27 
Indigenous Community v. Paraguay ${ }^{186}$ is arguably the most interesting example for our purposes, as the Court affirmed that "States must [...] adopt special measures to secure women, especially during pregnancy, delivery and lactation, access to adequate medical care services", in relation to State duty to adopt the special measure under Article 19 of the Convention that were necessary to protect the - born - children's life. ${ }^{187}$ However, in all these judgments, the protection ensured by the Court addressed the unborn indirectly, as a result of the protection granted to the right to physical and psychic integrity or the right to health of the mother and her right to access to adequate medical services during pregnancy and after the child's birth. This case law is interesting for understanding how the system of the Convention has tackled the protection of maternity. Nevertheless, the status of the unborn in that line of jurisprudence is not directly tackled and defined, although some recognition and protection, as stressed, is indirectly granted. The first opportunity that the IACtHR had to expressly grapple with the status of the unborn was the case of the Xákmok Kásek Indigenous Community v. Paraguay, ${ }^{188}$ but it skirted the question.

The case was basically focused on the protection of the ancestral land of the Xákmok Kásek Community, as the deprivation of their land had also caused the deprivation of the necessary means for living. The Court found a breach of the right to property of the applicants and also found that Paraguay had not adopted the necessary measures for protecting their right to life. Among the victims of the precarious living conditions, two nascituri were mentioned. Nonetheless, the Court held that "the representatives and the Commission have not presented arguments regarding the alleged violation of the right to life of the "unborn", thus it "lack[ed] facts on which to form an opinion as to the State's responsibility in these cases". ${ }^{189}$ However, since the causal link between the precarious living conditions of the Community and the deaths of the unborn children had been ascertained, it was reasonably stressed in scholarship that the Court's argument seems to clash with the principle iuva novit curia. ${ }^{190}$ Otherwise, when two years later the IACtHR was called upon to assess whether a right to access to IVF was protected under the ACHR in the Artavia Murillo v. Costa Rica case, ${ }^{191}$ it could not and did not skirt the issue of the status of the unborn again. The Court engaged in a careful interpretation of Articles

186 Inter-American Court of Human Rights, Case of Sawhoyamaxa Indigenous Community $v$. Paraguay, Judgment of 29 March 2006, Merits, Reparations and Costs, Series C No. 146.

187 Ibid., para. 177.

188 Inter-American Court of Human Rights, Case of Xákmok Kásek Indigenous Community v. Paraguay, Judgment of 24 August 2010, Merits, Reparations, and Costs, Series C No. 214, para. 2.

${ }^{189}$ Ibid., para 228.

190 See Díaz, Á. P., "Estatus del no nacido en la Convención Americana: un ejercicio de interpretación", cited above n. 173, p. 103.

${ }^{191}$ Inter-American Court of Human Rights, Case of Artavia Murillo et al. ("In vitro fertilization") v. Costa Rica, Judgment of 28 November 2012, Preliminary Objections, Merits, Reparations and Costs, Series C No. 257.

Araucaria. Revista Iberoamericana de Filosofia, Política, Humanidades y Relaciones Internacionales, año 20, ${ }^{\circ} 40$. Segundo semestre de 2018. Pp. 655-732. ISSN 1575-6823 e-ISSN 2340-2199 doi: 10.12795/araucaria.2018.i40.27 
4(1), 11, 17 of the ACHR when assessing the compatibility with ACHR of the decision of Constitutional Chamber of the Supreme Court of Costa Rica which, consistently with an absolute conception of the right to life from conception, had annulled the Executive Decree No. 24029-S of 1995, of the Ministry of Health of Costa Rica, ${ }^{192}$ that allowed IVF for married couples and regulated it.

The IACtHR, differently from the Strasbourg Court, made no use of the doctrine of the margin of appreciation, on which actually the IACtHR rarely relies in its case law and which was invoked by Costa Rica, when it claimed that no regional consensus existed on IVF and, thus, the matter was deferred to the discretional evaluation of the domestic legislator. Although some reference to regional consensus emerged in the Court's reasoning when dealing with the protection of the right to life with respect to IVF, as the technique is generally allowed in Latin America, nevertheless the Court's scrutiny was basically focused on proportionality.

Primarily, the interpretive efforts of the Court focused on the definition of the scope of application of Article 4(1) of the ACHR, by recalling thoroughly various techniques of interpretation. ${ }^{193}$ The Court relied on the method of the most favourable interpretation and highlighted that the aim of the wording of Article 4(1) is to allow appropriate balance between conflicting rights and interests, which excludes an absolute protection of the embryo that annuls other rights. ${ }^{194}$ However, at Paragraph 264 the IACtHR clarifies that the different methods of interpretation used "have led to similar results according to which the embryo cannot be understood to be a person for the purposes of Article 4(1) of the American Convention". Then, having also retraced the scientific debate on the beginning of life and the multidisciplinary approaches to the issue, the Court goes straight to the hub coming to the conclusion "that "conception" in the sense of Article 4(1) occurs at the moment when the embryo becomes implanted in the uterus, which explains why, before this event, Article 4 of the Convention would not be applicable". Moreover, embracing a progressive view on the development of the human embryo, the Court clarified that "it can be concluded from "the words "in general" that the protection of the right to life under [Article 4(1)] is not absolute, but rather gradual and incremental according to its development, since it is not an absolute and unconditional

${ }^{192}$ Executive Decree No. 24029-S of February 3, 1995, issued by the Ministry of Health.

193 The decision offers a thorough assessment based on the criteria of the ordinary meaning to be given to the terms of a treaty, the historical and systematic interpretation, the evolutive interpretation and the most favourable interpretation. In this regard, the Court respectively clarified that the locution "in general" allows exceptions, but it cannot be specified which according to the first method of interpretation used; secondly, systematic interpretation does not suggest that the embryo can be considered "a person" according to the relevant international instruments, the travaux préparatoires of the Convention and the rights enshrined in the ACHR and the ADRDM; nor evolutive interpretation through comparison among the regulations concerning the status of the embryo and the relevant IVF regulations and practices suggested that embryo could be considered "a person".

${ }^{194}$ Case of Xákmok Kásek Indigenous Community v. Paraguay, cited above n. 190, paras. 257 ff.; 164. 
obligation, but entails understanding that exceptions to the general rule are admissible". ${ }^{195}$ The consequences of this view are of outstanding importance, as this reading of Article 4 of the ACHR paves the way for accommodating scientific progress within the human rights framework of the Convention. Of course, some criticism addressed the decision from the opposite viewpoint. It was said that the ruling had prioritized the interests of biotechnology over the protection of early embryos, at odds with the Convention's wording that makes explicit reference to "conception". ${ }^{196}$ In this regard, in support of the ruling, it could be argued that, however, such reading is not clearly at odds with an evolutive interpretation of the ACHR. ${ }^{197}$ The Court's favour for scientific progress emerges also from the subsequent passages of the ruling, a with the results it has achieved comprehensively, as is analysed below.

After defining the scope of application of Article 4(1) of the Convention, the Court carried out a thorough test of proportionality when assessing Costa Rica's interference with the rights at stake in the case, namely personal integrity, personal liberty, private life, intimacy, reproductive autonomy, access to reproductive health services and the right to found a family, protected under Articles 5(1), 7, 11(2) and 17(2) of the ACHR. The Court provided an accurate and interesting definition of the scope and the content of the right to private life and its interconnection with the other entitlements involved. ${ }^{198}$ Similarly to the Strasbourg Court, the IACtHR has clarified that "the decision of whether or not to become a parent is part of the right to private life and includes, in this case, the decision of whether or not to become a mother or father in the genetic or biological sense". ${ }^{199}$ More in detail, the Court clarified that the case "addresse[d] a particular combination of different aspects of private life that are related to the right to found a family [that, according to the HRC, encompasses the possibility of procreating], ${ }^{200}$ the right to physical and mental integrity and, specifically, the reproductive rights of the individual." 201 In this regard, the Court specified that the right to private life encompasses reproductive autonomy that, in light of Article

195 Ibid., para. 264.

${ }^{196}$ Chia, E. A., Contreras, P., "Análisis de la Sentencia Artavia Murillo y Otros ("Fecundación In Vitro") vs. Costa Rica de la Corte Interamericana de Derechos Humanos", Estudios Constitucionales, vol. 12, $\mathrm{n}^{\circ}$ 1, (2014), pp. 567-585. Centro de Estudios Constitucionales de Chile. Santiago, Chile. Also see: Centro de Bioética, Admin, "Para la Corte Interamericana, el embrión no es persona", 21 December 2012, available at http://centrodebioetica.org/2012/12/para-la-corte-interamericana-elembrion-no-es-persona/ last accessed 23 June 2018.

197 Arévalo Narváez, C. E., Patarroyo Ramirez, P. A., "Treaties over Time and Human Rights: A Case Law Analysis of the Inter-American Court of Human Rights", Anuario Colombiano de Derecho Internacional (ACDI), $\mathrm{n}^{\circ}$ 10, (2017), pp. 295-331.

198 Case of Artavia Murillo et al. ("In vitro fertilization") v. Costa Rica, cited above n. 90, para. 146. Moreover, in this respect, "[t]he Court has indicated that motherhood is an essential part of the free development of a woman's personality", at para. 143.

199 Ibid., para. 143.

${ }^{200}$ Ibid., para 145.

201 Ibid., para. 144.

Araucaria. Revista Iberoamericana de Filosofia, Política, Humanidades y Relaciones Internacionales, año 20, ${ }^{\circ} 40$. Segundo semestre de 2018. Pp. 655-732. ISSN 1575-6823 e-ISSN 2340-2199 doi: 10.12795/araucaria.2018.i40.27 
16(e) of the Convention for the Elimination of All Forms of Discrimination against Women, includes the couple's decision to become genetic parents, ${ }^{202}$ and "access to reproductive health services, which includes the right to have access to the medical technology necessary to exercise this right." ${ }^{203}$ Recognizing the "connection between personal autonomy, reproductive freedom, and physical and mental integrity", 204 the IACtHR affirmed that "the rights to private life and to personal integrity are also directly and immediately linked to health care [and] [t] he lack of legal safeguards that take reproductive health into consideration can result in a serious impairment of the right to reproductive autonomy and freedom". ${ }^{205}$ In this respect, through its purposeful approach that recalls the relevant international reference instruments and jurisprudence, the Court incorporated in its legal reasoning the generalized understanding of sexual health that is shared at the international level, and framed it within the framework of the ACHR, by stating that " $[t]$ he right to reproductive health entails the rights of men and women to be informed and to have free choice of and access to methods to regulate fertility, that are safe, effective, easily accessible and acceptable", which also includes access to IVF. ${ }^{206}$ This legal reasoning led the Court to specify that "the right to private life and reproductive freedom is related to the right to have access to the medical technology necessary to exercise that right" and, differently from the Strasbourg Court, the IACtHR affirmed and protected in the case "the right to enjoy the benefits of scientific progress [that] has been internationally recognized" ${ }^{207}$ Curiously enough, the Court recalled Article 15 of the ICESCR in a footnote ${ }^{208}$ and did not expressly incorporate it in the text of the judgement as could be expected in line with its usual approach considered above. Otherwise, in Artavia Murillo judgment, when affirming "[t]he right to have access to scientific progress in order to exercise reproductive autonomy and the possibility to found a family", ${ }^{209}$ the Court basically elucidated its scope by making reference to the Inter-American system, which provides references of basic importance and helped the Court to give a proactive reading of this right. In particular, the Court relied on Articles 11(2) and 17(2) in light of the principle pro person ${ }^{210}$ pursuant

\footnotetext{
202 Ibid., para. 146.

203 Ibid.

204 Ibid., para. 147.

205 Ibid.
}

${ }^{206}$ In particular, the IACtHR recalled the jurisprudence of the UN Committee on Economic, Social and Cultural Rights, the Cairo Programme of Action of the International Conference on Population and Development, and the Declaration and Platform for Action of the Fourth World Conference on Women. In this regard, see Ibid., para. paras. 146 and 149.

207 Ibid., para. 150.

208 Ibid., footnote 251.

209 Ibid., para. 150.

210 Feria Tinta, M., The Landmark Rulings of the Inter-American Court of Human Rights on the Rights of the Child. Protecting the Most Vulnerable at the Edge, Leiden, Boston, Martinus Nijhoff Publishers, 2008; Burgorgue Larsen, L., Ubeda de Torres, A., The Inter-American Court of Human Rights: Case Law and Commentary, Oxford, New York, Oxford University Press, 2011. 
to Article 29(b) of the ACHR, in connection with Article XIII of the ADRDM and Article 14(1)(b) of the Protocol of San Salvador. ${ }^{211}$ As a result, the Court held that the right under consideration "gives rise to the right to have access to the best health care services in assisted reproduction technology, and, consequently, the prohibition of disproportionate and unnecessary restrictions, de iure or de facto, to exercise the reproductive decisions that correspond to each individual". ${ }^{212}$ In relation to this assessment, the Court scrutinized the proportionality of the interference caused by Costa Rica, by analysing thoroughly the impact of the absolute protection granted to the right to life of the human embryo and finding that "one of the direct interferences in private life is related to the fact that the Constitutional Chamber's decision prevented the couples from deciding whether or not they wished to submit to this treatment to have children in Costa Rica". ${ }^{213}$ In fact, the IACtHR considered that having to look for IVF abroad as the only viable route for accessing the treatment was unfair, ${ }^{214}$ this is very a different view from the one expressed by the ECtHR in the S.H. v. Austria judgment with reference to accessibility to cross-border healthcare. Moreover, IACtHR found that the interference of Costa Rica had a disproportionate impact and caused an indirect discrimination on the grounds of disability, gender and financial conditions. ${ }^{215}$ Finally, the Court scrutinized the proportionality of the State's interference in relation to the embryonic loss in IVF and, in this regard, it considered that since "embryonic loss exists in both natural pregnancy and in [...] other reproduction techniques permitted in Costa Rica, the protection of the embryo sought by banning IVF has a very limited and moderate scope". 216

It is in light of all these considerations that the IACtHR came to the conclusion that the "Constitutional Chamber based itself on an absolute protection of the embryo that, by failing to weigh up or take into account the other competing rights, involved an arbitrary and excessive interference in private and family life that makes this interference disproportionate [and] moreover, the interference had discriminatory effects". ${ }^{217}$ Having said that, the Court explicitly held that it was not taking into consideration State's arguments about the margin of appreciation although, as anticipated above, in the ruling, some reference to consensus emerged in its legal reasoning, when it underline that Costa Rica was the only country that prohibits IVF in the region and, then, does not practice it. ${ }^{218}$

${ }^{211}$ Organization of American States (OAS), Additional Protocol to the American Convention on Human Rights in the Area of Economic, Social and Cultural Rights ("Protocol of San Salvador") (adopted 16 November 1999, entered into force 16 November 1999) A-52, available at http://www. oas.org/juridico/english/treaties/a-52.html last accessed 23 June 2018.

${ }^{212}$ Case of Artavia Murillo et al. ("In vitro fertilization”) v. Costa Rica, cited above n. 90, para. 150.

213 Ibid., para. 277.

214 Ibid., paras. 279, 304, 347 ff.

${ }^{215}$ Ibid., para. 316.

216 Ibid., para. 313.

${ }^{217}$ Ibid., para. 316.

218 Ibid.

Araucaria. Revista Iberoamericana de Filosofia, Política, Humanidades y Relaciones Internacionales, año 20, $\mathrm{n}^{\circ} 40$ Segundo semestre de 2018. Pp. 655-732. ISSN 1575-6823 e-ISSN 2340-2199 doi: 10.12795/araucaria.2018.i40.27 
One year after the Artavia Murillo judgment, in 2013, the IACtHR was called upon to express its view in the case of Beatriz; what emerges, again, from the Court's legal reasoning is that the protection of the unborn is not absolute and the balance has to be properly stricken among the safeguarding of the nasciturus and the conflicting rights of the mother at stake. In the Beatriz case, the focus was set on the foetus and the Court had to decide on a provisional measure concerning abortion rights in El Salvador, a country that contemplates one of the strictest regulations in the region in this field. Criminalization of abortion is particularly severe in the country, as women are exposed to up to fifty-years imprisonment in case the facts are legally qualified as aggravated murder. The ban on abortion is outright in the country and the applicant, who was named "Beatriz" for protecting her privacy, had a very delicate situation: she suffered from several severe autoimmune diseases, namely Systemic Lupus Erythematosus aggravated with lupus nephritis and rheumatoid arthritis, and the pregnancy posed a threat to her physical and mental integrity and, eventually, to her life. ${ }^{219}$ What is more, several ultrasounds had shown that the foetus was affected by anencephaly and had very little chances of survival after birth.

Notwithstanding this and despite the IACHR had requested that El Salvador "adopt[ed] the necessary measures to implement the treatment recommended by the Medical Committee of the National Hospital [...] aiming to protect the life, personal integrity and health of [Beatriz]"220, the Salvadoran Supreme Court considered that the threat to the life of Beatriz was not "actual or imminent". Then, according to the test of proportionality it carried out, it concluded that right to life of the mother and the right to life of the foetus deserved equal protection and did not allow the termination of pregnancy under those circumstances. ${ }^{221}$ In its resolution on the provisional measure, the IACtHR, requested to act by the Commission, under the circumstances of the

219 The situation was so serious that it raised the attention of the international community: it triggered a mediatic storm and a Group of Experts of the United Nations issued an appeal to El Salvador for authorizing Beatriz to undergo the necessary therapeutic abortion Among the Experts were included: the Special Rapporteur on violence against women, Rashida Manjoo; the Chairperson of the Working Group on the issue of discrimination against women in law and practice, Kamala Chandrakirana; the Special Rapporteur on torture and other cruel, inhuman or degrading treatment or punishment, Juan Méndez; and the Special Rapporteur on the right of everyone to the enjoyment of the highest attainable standard of physical and mental health, Anand Grover. An overview of the UN Group of Expert's intervention and appeal can be found here: https://newsarchive.ohchr.org/EN/ NewsEvents/Pages/DisplayNews.aspx?NewsID=13404\&LangID=E last accessed 13 June 2018. See: BASOĞLU, M., Torture and Its Definition in International Law: An Interdisciplinary Approach, Oxford, New York, Oxford University Press, 2017, pp. 233 ff.; OBERMAN, M., Her Body, Our Laws: On the Front Lines of the Abortion War, from El Salvador to Oklahoma, Boston, Beacon Press, 2018, pp. $14 \mathrm{ff}$.

${ }^{220}$ Inter-American Court of Human Rights, Matter of B., order of 29 May 2013, Provisional Measures regarding El Salvador, Order of the Inter-American Court of Human Rights of 29 May 2013.

221 Arango Olaya, M., "Inter American Court of Human Rights provisional measures adopted in B. v. El Salvador case and the strengthening of reproduction rights in the inter-American system", Anuario de Derechos Humanos, $\mathrm{n}^{\circ}$ 10, (2014), pp. 177-185 
case prioritized the right to life and the right to physical and mental integrity of the mother over the alleged right to life of the foetus. ${ }^{222}$

The Court found that all the requirements for granting the provisional measure, namely extreme seriousness, urgency and the risk of an irreparable harm, were met: first of all "Beatriz" was in need of constant medical treatment and the aggressive medications she took posed a risk to her health and, definitely, to her life; her health conditions might have become critical unpredictably; finally, pregnancy and the condition of anencephaly that affected the foetus might exacerbate her health conditions and, moreover, she was undergoing such psychological suffering that she had begun to show some psychosomatic symptomatology. ${ }^{223}$ Therefore, the IACtHR, conclusively, "require[d] that the State of El Salvador adopted and guaranteed, with urgency, all the necessary and effective measures so that the medical staff treating Mrs. B. can adopt, without any interference, the medical measures considered appropriate and convenient for ensuring due protection to the rights enshrined in Articles 4 and 5 of the American Convention and, in this way, to prevent irreparable harm to the rights to life and physical integrity and health of Mrs. B". ${ }^{224}$ The resolution confirmed the view expressed by the Court in the Artavia Murillo judgment, namely that the protection of the unborn is progressive and gradual. It means that under distinct circumstances the Court may strike a different balance between the conflicting interests at stake and prioritize the protection of the nasciturus. ${ }^{225}$ In scholarship, it was suggested that the Court's view in the Artavia Murillo judgment and in the resolution on the case of Beatriz was in line the conception that the Court has embraced that only persons are entitled the rights enshrined

${ }^{222}$ For a wider overview of provisional measures in the jurisprudence of the IACtHR, see Pasqualucci, J. M., The Practice and Procedure of the Inter-American Court of Human Rights, Cambridge, New York, Melbourne, Madrid, Cape Town, Cambridge University Press, 2013, pp. 254 ff.

${ }^{223}$ See respectively paragraphs 12,13 and 14 of the resolution. With regard to the irreparable harm, the anencephaly from which the foetus suffered might have caused such diseases as obstetric haemorrhage, worsening of lupus, renal insufficiency and serious preeclampsia and the related complications that it might bring about. Moreover, from the psychological viewpoint, Beatriz was facing a situation of profound distress, which was in part related to her concerns about her survival and, thus, the possibility to take care of her son, who was few years old; in this regard, as stressed above, she was already showing some psychosomatic symptomatology.

224 Translation by the Author. The original text of the Resolution reads as follows: [La Corte resuelve] "Requerir al Estado de El Salvador que adopte y garantice, de manera urgente, todas las medidas que sean necesarias y efectivas para que el grupo médico tratante de la señora B. pueda adoptar, sin interferencia alguna, las medidas médicas que se consideren oportunas y convenientes para asegurar la debida protección de los derechos consagrados en los artículos 4 y 5 de la Convención Americana y, de este modo, evitar daños que pudiesen llegar a ser irreparables a los derechos a la vida y la integridad personal y a la salud de la señora B., conforme a lo expresado en los párrafos considerativos 11 a 17 de la presente Resolución”. In practice Beatriz did not abort, but she was authorized to terminate pregnancy with a caesarean section, as she was already 27 weeks pregnant.

${ }^{225}$ See Arango Olaya, M., "Inter American Court of Human Rights provisional measures adopted in B. v. El Salvador case and the strengthening of reproduction rights in the inter-American system", cited above n. 220. 
in the Constitutions. ${ }^{226}$ The human embryo or the foetus would not be included in this notion and, therefore, they would enjoy a protection that is defined according to the potential of life they enshrine.

From a comprehensive viewpoint, the outcome is that the IACtHR has played a basic role for the affirmation and the protection of reproductive rights in the region and has adopted a proactive reading capable of embracing the right to enjoy advanced reproductive techniques and biotechnology, through a proactive reading of States' duties and individuals' rights under the system of the ACHR and the Inter-American human rights instruments. In this regard, the Court has enhanced the authoritativeness of the protection it has ensured and promoted, ${ }^{227}$ through incorporation in its legal reasoning and in the definitions provided of the internationally shared views. The incorporation of the internationally shared understanding of sexual health and reproductive rights is a paradigmatic example. This approach upholds the Court's legitimation ${ }^{228}$ in its relationship with States Parties, which is particularly important, for example, to establish a balanced dialogue with national courts as to their role in the conventional scrutiny since, as well as the legislator, they have to incorporate into domestic jurisprudence the standard elaborated by the IACtHR in its case law. ${ }^{229}$ A cooperative approach is fundamental for preventing a clash between the two levels of jurisdiction, that might the authoritativeness of the decisions of the IACtHR. The sensitiveness of the situation has clearly emerged in both Artavia Murillo and Beatriz cases. In this regard it is interesting to recall that some Latin American States have incorporated, in their Constitutions, a clause called "bloque de constitucionalidad". ${ }^{230}$ According to this kind of clauses, which were initially incorporated in the European Constitutions of Portugal and Spain and which can be found, for instance, in the Latin American Constitutions of

226 See Chia, E. A., Contreras, P., “Análisis de la Sentencia Artavia Murillo y Otros ("Fecundación In Vitro") vs. Costa Rica de la Corte Interamericana de Derechos Humanos", cited above n. 190, p. 576.

227 See Valerio, C., Vargas, K., Raventós, H., "IVF in Costa Rica", JBRA Assisted Reproduction, ${ }^{\circ}$ 21(4), (2017), pp. 366-369. See also VON Bogdandy, A., Ferrer Mac-Gregor, E., Morales Antoniazzi, M., Piovesan, F., Transformative Constitutionalism in Latin America: The Emergence of a New Ius Commune, Oxford, New York, Oxford University Press, 2017, pp. 61 ff.

${ }_{228}$ See: Chia, E. A., Contreras, P., "Análisis de la Sentencia Artavia Murillo y Otros ("Fecundación In Vitro") vs. Costa Rica de la Corte Interamericana de Derechos Humanos", cited above n. 190; Lemaitre, J., Sider, R., "The Moderating Influence of International Courts on Social Movements: Evidence from the IVF Case Against Costa Rica”, Health and Human Rights Journal, (6 June 2017), available at https://www.hhrjournal.org/2017/06/the-moderating-influence-of-international-courtson-social-movements-evidence-from-the-ivf-case-against-costa-rica/ last accessed 25 June 2018.

${ }^{229}$ Chia, E. A., Contreras, P., "Análisis de la Sentencia Artavia Murillo y Otros ("Fecundación In Vitro") vs. Costa Rica de la Corte Interamericana de Derechos Humanos", cited above n. 190. See: Inter-American Court of Huan Rights, Gelman vs. Uruguay, Judgment of 24 February 2011, Merits and Reparations, Serie C N 221

${ }^{230}$ Ruiz Miguel, A., Derecho a la Vida y Constitución: Consecuencias de la Sentencia de la Corte Interamericana de Derechos Humanos "Artavia Murillo v. Costa Rica"”, Estudios Constitucionales, Año 12, n 1, (2014), pp. 71-104, p. 77.

Araucaria. Revista Iberoamericana de Filosofía, Política, Humanidades y Relaciones Internacionales, año 20, $\mathrm{n}^{\circ} 40$ Segundo semestre de 2018. Pp. 655-732. ISSN 1575-6823 e-ISSN 2340-2199 doi: 10.12795/araucaria.2018.i40.27 
Argentina, Bolivia, Colombia, Mexico and Venezuela, ${ }^{231}$ international human rights law is constitutionalized, that means it is incorporated within the national legal order with constitutional rank. ${ }^{232}$ This entails that national institutions, either political or jurisdictional, should foster the convergence of international human rights law and constitutional law, easing the correspondence between their scope and content. ${ }^{233}$ That being said, it should be stressed that there is also another relevant consequence related to the bloque de constitucionalidad, namely the prevalence of the rules of international human rights law when it provides a higher threshold of protection, consistently with the principle pro persona. ${ }^{234}$ As the Court's ruling in the Artavia Murillo case demonstrates, this principle may be fruitfully used for paving the way for generalized enjoyment of reproductive rights, also through access to the most advanced achievements of scientific progress. For sure, there is still a long way to go, although the "wind of change" blowing on Latin America actually seems to be promising for the success of the process promoted in the Inter-American jurisprudence.

\section{A comparison between the jurisprudence of the IACtHR and of the ECtHR and some proposals for judicial dialogue and enhancement of the protection ensured}

The assessment carried out in the previous paragraphs shows that a core conception of reproductive rights and sexual and reproductive health has emerged at the international level and the ECtHR and the IACtHR have incorporated this view in their jurisprudence, although with some differences

\footnotetext{
${ }^{231}$ Ibid.

${ }^{232}$ A comparison might help to clarify the relevance of the bloque de constitucionalidad: for example, in Italy, international law shares the same rank as the provision or set of provisions that incorporate it within the national legal order. Customary international law has constitutional rank because Article 10 of the Italian Constitution is the provision that incorporates it, whilst conventional law has the rank of ordinary law, although Italian scholarship has recognized that they have "special resistance", which means that their rank is "enhanced" in comparison with ordinary law.

${ }^{233}$ This view are expressed and thoroughly dealt with in the article Ruiz Miguel, A., Derecho a la Vida y Constitución: Consecuencias de la Sentencia de la Corte Interamericana de Derechos Humanos “Artavia Murillo v. Costa Rica"”, cited above n ${ }^{\circ} 229$. Moreover, it is interesting to mention few rulings of Latin American Constitutional Courts concerning the influence of the Inter-American jurisprudence over domestic institutions. Of course, the decisions of the IACtHR are binding only on the States they address pursuant to Article 68 of the ACHR. Nevertheless, some Constitutional Courts have theorized they can provide some guidance for the national courts, as the Mexican Supreme Court, that held that the decisions of the IACtHR are "orientadoras", that is, they should guide, Mexican judges. In an arguably less incisive way, the Supreme Court of Argentina has maintained that the interpretation of the ACHR is informed by the reading and the guidance provided by the IACtHR. Otherwise, the Supreme Court of Uruguay has held that no duty of international law exists in the sense of following the jurisprudence of the IACtHR and remarked that the Constitutional itself is the body ultimately tasked with the interpretation of the Constitution.

${ }^{234}$ Ibid., p. 77 on this view.
} 
and to a distinct extent. In the case law of the IACtHR, the proactive approach embraced and thoroughly underpinned by reference to the relevant international instruments and jurisprudence has adopted an advanced reading of reproductive rights, capable of promoting the process of rejuvenation of human rights law in order to keep the pace with scientific progress. Otherwise, the ECtHR has a more evident tendency to self-restrain, although some important results were achieved. The R.R. v. Poland and the Costa and Pavan v. Italy judgments are effective examples.

Therefore, we could wonder what we may expect from the evolution of the case law of the two Courts and whether judicial dialogue might be a fruitful route to take. In this respect, primarily, some considerations should be made on the reasons for the differences in their approach, in order to assess how the existing limitations but also the viable paths to enhanced and scientifically advanced protection of reproductive rights in international law may interact with the Court's views.

First off, the IACtHR is generally more proactive than the Strasbourg Court and also less self-referential. The reason has to be sought in the process of affirmation of the IACtHR, that had to struggle more than the ECtHR in this respect: reference to the relevant hard and soft law instruments of international law and to international jurisprudence helped the Court to provide more authoritativeness to its decisions. Additionally, it has helped to increase the threshold of protection, as the San José Court recalls to the relevant international references aiming to ensure the highest standards of protection possible, according to the more favourable protection clause, in a way which was effectively defined in scholarship as "cherry picking". ${ }^{235}$ Furthermore, the IACtHR can rely on a wider catalogue of human rights enshrined in the ACHR, that can offer useful legal bases when dealing with reproductive rights.

In this regard, in the Artavia Murillo judgment, the Court has stressed that "unlike the European Convention on Human Rights, which only protects the right to family life under Article 8 [...] the American Convention contains two articles that protect family life in a complementary manner", namely Article 11(2) and Article 17 of the Convention that protect "the rights of the family" that the family's right to protection entails, among other obligations, facilitating, in the broadest possible terms, the development and strength of the family unit". However, in this respect, it should be considered that the ECHR,

\footnotetext{
${ }^{235}$ Groppi, T., Lecis Cocco Ortu, A.M., "Le citazioni reciproche tra la Corte Europea e la Corte Interamericana dei Diritti dell'Uomo: dall'influenza al dialogo?", cited above n. 166, p. 36. For wider analysis of the use of the more favourable protection clause in the jurisprudence of the ECtHR and of the IACtHR, see Rachovitsa, A., "Treaty Clauses and Fragmentation of International Law: Applying the More Favourable Protection Clause in Human Rights Treaties", Human Rights Law Review, n. 16 (1), (1 March 2016), pp. 77-101.
} 
besides Article 8, contains also Article 12, that protects the right to marry and to found a family. Nevertheless, this provision was not recalled by the Court in relation to reproductive rights, even when it might have helped to better define and underpin the human rights framing of the issues considered, for example, in the Costa and Pavan and Parrillo rulings. In that regard, it should be taken into account that Article 12 protects the right to marry and to found a family "according to the national laws governing [their] exercise" but does not contain additionally a similar statement as the ACHR, which adds "insofar as such conditions do not affect the principle of non-discrimination". However, some guidance for defining better the scope of Article 12 of the ECHR and how it interrelated with national laws, is provided by the Court's case law in the field of same-sex couples marriage. For example, in the case of Schalk and Kopf $v$. Austria ${ }^{236}$ the Strasbourg Court had the chance to restate, as it had often done in its established case law, that "[although t]he exercise of this right [...] is "subject to the national laws of the Contracting States", [...] the limitations thereby introduced must not restrict or reduce [it] in such a way or to such an extent that the very essence of the right is impaired", but usually has allowed a wide margin of appreciation.

Moreover, the catalogue of human rights protected in the InterAmerican system is complemented by the Protocol of San Salvador that contains a specific legal basis concerning the right to enjoy the benefits of scientific progress, namely Article 14 on the right to the benefits of culture, that has paved the way to the affirmation of access to reproductive technology in the Artavia Murillo judgment, where the Court had affirmed the "right to have access to the medical technology necessary to exercise th[e] right [to private life and to reproductive freedom]". ${ }^{237}$ Although not all States Parties to the ACHR have signed and ratified the Protocol of San Salvador, Article XIII of the ADRDM ${ }^{238}$ would provide a legal basis as well with regard to the right to the benefits of culture, as it foresees the right "to participate in the benefits that result from intellectual progress, especially scientific discoveries". In this regard, the Strasbourg Court cannot rely on a similar targeted legal basis in the ECHR system, which makes its interpretive efforts harder.

Furthermore, as anticipated in the previous paragraph, the conception of the right to life adopted in the Inter-American jurisprudence, has played an important role for helping the Court to affirm access to reproductive

\footnotetext{
${ }^{236}$ European Court of Human Rights, Schalk and Kopf v. Austria, Judgment of 24 June 2010, Appl. No. 30141/04, Reports of Judgments and Decisions 2010. para. 49, available at https:/hudoc.echr. coe.int/eng\# \{\%22fulltext $\% 22:[\% 22 \mathrm{kopf} \% 22], \% 22$ documentcollectionid2\%22:[\%22GRANDCHA MBER\%22,\%22CHAMBER\%22],\%22itemid\%22:[\%22001-99605\%22]\}

${ }^{237}$ Artavia Murillo et al. ("In vitro fertilization”) v. Costa Rica, cited above n. 90, para. 150.

${ }^{238}$ In particular, Article XIII of the ADRDM at para. 1 provides that: "Every person has the right [...] to participate in the benefits that result from intellectual progress, especially scientific discoveries."
} 
technologies and the enjoyment of reproductive rights, including abortion, under the ACHR system. Indeed, by affirming that the right to life of the unborn is not absolute and that it deserves progressive protection, the Court has tackled the issue of the beginning of life in a way that attempts to provide a balanced protection to both the unborn and the conflicting reproductive rights, and that allows a case by case scrutiny. In this respect, the standard of proportionality has allowed a wider assessment to the Court: although in the Artavia Murillo case, possibly, the application of the margin of appreciation would have led to similar conclusions due to the existence of a regional consensus on IVF, the same can hardly be said in relation to the scrutiny on abortion rights, as they do not find the same acceptance regionally. Nevertheless, the results achieved by the Strasbourg Court should not be underestimated. Basically, because the Court has been capable of making the guarantees enshrined in the Convention effective by turning a treaty adopted in the 1950 into a "living instrument" capable of encompassing biorights. It is clearly praiseworthy. The Court has succeeded to include within the scope of the ECHR genetic parenthood and access to PGD and prenatal diagnosis. It has succeeded to provide at least procedural protection to abortion rights but, nonetheless, the variety of regional views on the beginning of life precludes any scrutiny on the issue substantially. In this regard, the slash criticism raised by the decision issued by the other European major Court, the Court of Justice of the European Union (ECJ) in the Brüstle case, ${ }^{239}$ in relation to

239 European Court of Justice (Grand Chamber), Oliver Brüstle v Greenpeace eV., Judgment of 18 October 2011. Reference for a preliminary ruling: Bundesgerichtshof - Germany, Case C-34/10, European Court Reports of Cases 2011 I-09821. In that ruling, the ECJ was called upon provide interpretive guidance in relation to the notion of human embryo relevant under Article 6(2)(c) of Directive 98/44/EC. The ECJ held that "including any human ovum after fertilisation, any nonfertilised human ovum into which the cell nucleus from a mature human cell has been transplanted and any non-fertilised human ovum whose division and further development have been stimulated by parthenogenesis constitute a "human embryo", due to their capacity of "commencing the process of development of a human being". This view was criticized as it was considered too limitative for research, especially in light of the "variable geometry" of research on embryo in Europe (in this regard, see García San José, D. I., European Normative Framework for Biomedical Research in Human Embryos, cited above n. 10, p. 98. Regulation on human embryo research in Europe ranges from the permissive legislation of Spain and the United Kingdom, which allow embryo creation for research purposes, to the strict regulation provided by Italy and Germany, for example, that cannot create human embryonic stem cells but can import them). Nor the more flexible reading advanced three years later in the International Stem Cells judgment where the Court focused on the definition of which stage marked the development of the human embryo into the human being, was uncriticized (see: European Court of Justice (Grand Chamber), International Stem Cell Corporation v Comptroller General of Patents, Designs and Trade Marks, Judgment of 18 December 2014. Request for a preliminary ruling from the High Court of Justice (England \& Wales), Chancery Division (Patents Court). Case C-364/13, Digital reports (Court Reports - general). That being said, this example is emblematic of the difficulties that the ECtHR would meet in case it attempted to tackle the beginning of life. So far, the recognition of the "potential of life" of the human embryo is an interesting step and may help reconciling the different domestic view. However, it does not arguably allow such a scrutiny as the notion adopted by the IACtHR.

Araucaria. Revista Iberoamericana de Filosofia, Política, Humanidades y Relaciones Internacionales, año 20, ${ }^{\circ} 40$. Segundo semestre de 2018. Pp. 655-732. ISSN 1575-6823 e-ISSN 2340-2199 doi: 10.12795/araucaria.2018.i40.27 
Human Rights and the European Court of Human Rights

Directive 98/44/EC ${ }^{240}$ and human embryo research, confirms how pluralism is hard to tackle in Europe. This helps to clarify why the doctrine of the margin of appreciation has played a basic role in the jurisprudence of the Court, ${ }^{241}$ in general and especially in the field of biorights. Indeed, it has helped to establish a balanced relationship between the ECtHR and States Parties, although the Court has not needed to struggle as much as the Inter-American Court for its affirmation in its regional framework. However, in the last years, some countries have shown some reluctance and have demonstrated to be unwilling to comply with the Court's judgments. ${ }^{242}$

The Strasbourg Court is aware of the pressure that is put on it, even more when it comes to scrutinizing bioethically sensitive cases and it has emerged in its case law. In fact, the Judges Tulkens, Hirvelä, Lazarova Trajkovska and Tsotsoria, in their Joint Dissenting Opinion in the case of S.H. v. Austria, in relation to the consideration given by the Court to the consensus on gamete

${ }^{240}$ Directive 98/44/EC of the European Parliament and of the Council of 6 July 1998 on the legal protection of biotechnological inventions, available at https://eur-lex.europa.eu/legal-content/EN/ TXT/?uri=celex\%3A31998L0044 last visited 20 July 2018.

${ }^{241}$ This is arguably so especially since the 1990 s, when the number of Member States of the COE and thus the figure of the States Parties to the ECHR and subject to the jurisdiction of the Court has increased at an appalling rate. And, of course, also the variety and pluralism of views and ethical standards to reconcile and to protect in the human rights language of the Convention. The theory of the margin of appreciation has ensured a balanced interrelationship between the ECtHR and the States also in the long term.

242 For example, it was the case for the United Kingdom in relation to the issue of the disenfranchisement of prisoners, as in the Hirst case, or Russia, especially with respect to the Konstantin Markin case. The tension between the Court and the States Parties seemed to culminate in the Draft Copenhagen Declaration - especially with respect to its approach to subsidiarity and to the margin of appreciation - which was intended to review the ECtHR, that seemed to "empower the executives of states and weaken the Court". (which is available at https:/www.echr.coe.int/Documents/ Opinion_draft_Declaration_Copenhague\%20ENG.pdf last visited 15 July 2018. In this regard, see https://www.ejiltalk.org/the-draft-copenhagen-declaration-whose-responsibility-and-dialogue/). See: European Court of Human Rights, Hirst v. the United Kingdom (2), Judgment of 6 October 2005, Appl. No. 74025/01, available at https://hudoc.echr.coe.int/eng\#\{\%22dmdocnumber\%22:[\%227874 85\%22],\%22itemid\%22:[\%22001-70442\%22]\} last visited 12 July 2018; European Court of Human Rights, Konstantin Markin v. Russia, Judgment of 22 March 2012, Appl. No. 30078/06, available at https://hudoc.echr.coe.int/eng\# \{\%22fulltext $\% 22:[\% 22$ konstantin $\% 22], \% 22$ documentcollectionid $2 \%$ 22:[\%22GRANDCHAMBER\%22,\%22CHAMBER\%22],\%22itemid\%22:[\%22001-109868\%22]\} last visited 12 July 2018. See FLEIG-GOLDSTEIN, R. M., "The Russian Constitutional Court versus the European Court of Human Rights: How the Strasbourg Court Should Respond to Russia's Refusal to Execute ECtHR Judgments", Columbia Journal of Transnational Law, available at http:// jtl.columbia.edu/the-russian-constitutional-court-versus-the-european-court-of-human-rights-howthe-strasbourg-court-should-respond-to-russias-refusal-to-execute-ecthr-judgments/ last visited 12 July 2018. It seems interesting to recall also that, for the first time in history after the entry into force of Protocol No. 14, that introduced Section 4 in the text of Article 46 of the ECHR, the Committee of Ministers has started an infringement proceeding against Azerbaijan due to the non-enforcement of the Mikayil Mammadov v. Azerbaijan (European Court of Human Rights, Mikayil Mammadov v. Azerbaijan, Judgment of 17 December 2009, Appl. No. 4762/05, available at https://hudoc.echr. coe.int/eng\#\{\%22fulltext $\% 22:[\% 22$ mammadov $\% 22], \% 22$ documentcollectionid $\% 22:[\% 22$ GRAND CHAMBER \%22,\%22CHAMBER\%22],\%22itemid\%22:[\%22001-96337\%22]\} last visited 12 July 2018).

Araucaria. Revista Iberoamericana de Filosofia, Politica, Humanidades y Relaciones Internacionales, año 20, $\mathrm{n}^{\circ} 40$ Segundo semestre de 2018. Pp. 655-732. ISSN 1575-6823 e-ISSN 2340-2199 doi: 10.12795/araucaria.2018.i40.27 
donation for the purpose of IVF, have highlighted that "[t] he current climate is probably conducive to such a backward step". Moreover, the Judges warned about the risks, as the fact that "[ $\mathrm{t}]$ he differences in the Court's approach to the determinative value of the European consensus and a somewhat lax approach to the objective indicia used to determine consensus are pushed to their limit here, engendering great legal uncertainty". ${ }^{243}$

Therefore, also for preventing such risks in the Strasbourg jurisprudence, it is interesting to consider whether and to which extent the protection of reproductive rights may benefit from judicial dialogue between the results achieved by the ECtHR and the IACtHR. Judicial dialogue, or crossfertilization, would also arguably benefit the case law of the two Court by curbing fragmentation: this seems particularly important in such a field as reproductive rights that is required to face transboundary and global challenges and where reproductive tourism ${ }^{244}$ poses serious threats to social justice, since only wealthy couples have the chance to travel for accessing to reproductive service available abroad. And, in this respect, it is compelling to "assum[e] justice as fairness in the distribution of the benefits and burdens of public policy in a pluralistic society", ${ }^{245}$ and human rights, including reproductive rights, implementation at the domestic level can help.

In light of the comparison between the results achieved by the two Courts, it may be argued that, as a primary step, the Strasbourg Court may benefit from some reference to the jurisprudence of the IACtHR through judicial dialogue. Despite its traditional self-referential approach, the Strasbourg Court has already begun to adopt a renewed perspective and to progressively make increasing reference to the San José case law. This trend began in the 2000s, when the ECtHR had to face new challenges due to the renewed composition of States Parties begun in the Nineties, and the experience of the IACtHR in the field of some gross violations turned out to be a precious reference. ${ }^{246}$ Despite in general the ECtHR has developed a wider and established experience in the field of biolaw, some reference to the views elaborated in San José would

${ }^{243}$ S.H. and Others v. Austria, cited above n. 137, Joint Dissenting Opinion of Judges Tulkens, Hivelä, Lazarova Trajkovska and Tsotsoria, para. 9.

${ }^{244}$ Rodotà, S., Il diritto di avere diritti, cited above n. 9, p.88; Farnós Amorós, E., “Debe permitirse la gestación por sustitución en España? Estado de la cuestión y algunas reflexiones", cited above n. 142, pp. 195, 234, 222 ff.; Yildiz, M. S., Khan, M. M., "Opportunities for reproductive tourism: cost and quality advantages of Turkey in the provision of in-vitro Fertilization (IVF) services", BMC Health Services Research, $\mathrm{n}^{\circ}$ 16, (2016), pp. 378-385.

${ }^{245}$ García San José, D.I., International Bio Law. An International Overview of Developments in Human Embryo Research and Experimentation, cited above n. 10, p. 162. Also see: Chevernak, F. A., Mccullough, L. B., "How physicians and scientists can respond responsibly and effectively to religiously based opposition to human embryonic stem cell research", Fertility and Sterility, vol. 90, $\mathrm{n}^{\circ} 6,(2008)$, pp. 2056-2059.

${ }^{246}$ Groppi, T., Lecis Cocco Ortu, A.M., "Le citazioni reciproche tra la Corte Europea e la Corte Interamericana dei Diritti dell'Uomo: dall'influenza al dialogo?’, cited above n. 166, pp. 35, 37.

Araucaria. Revista Iberoamericana de Filosofía, Política, Humanidades y Relaciones Internacionales, año 20, $\mathrm{n}^{\circ} 40$. Segundo semestre de 2018. Pp. 655-732. ISSN 1575-6823 e-ISSN 2340-2199 doi: 10.12795/araucaria.2018.i40.27 
help to enhance the guarantees ensured in the field of reproductive rights in the ECHR system. Curiously enough, in this regard, the IACtHR has been capable of valorising more the nature of the ACHR as a living instrument, in line with that "idem sentire" 247 that it shares with the Strasbourg Court in this respect.

In particular, the Strasbourg Court would benefit from reference to the proactive and less self-referential approach of the San José Court and its capacity to recall the relevant international sources of both hard and soft law in order to enhance the protection of the conventional rights. ${ }^{248}$ This would be beneficial for the Strasbourg Court for improving the incorporation in its case law of the generally recognized core conception of sexual and reproductive health and reproductive rights, through an enhanced reading of the rights protected under the ECHR, primarily Article 8. In this regard, the Artavia Murillo judgment is a paradigmatic example, and reference would be particularly helpful with regard to access to ARTs and, in particular, IVF. This is true, especially, when it is considered that this approach, as analysed above, has allowed the IACtHR to advance a reading of the scope of the right to private life capable of encompassing access to reproductive health services that includes "the right to have access to the medical technology necessary to exercise this right" 249 and a reading of Articles 11(2) and 17(2) of the ACHR in light of the principle pro persona according to which "the scope of the rights to private life, reproductive autonomy and to found a family, derived from [those provisions] extends to the right of everyone to benefit from scientific progress and its applications".

The incorporation of access to reproductive services and to the necessary reproductive technology, including scientific progress and its applications, as an integral component of private life would help the Strasbourg Court to provide wider generalized protection to reproductive rights and would also enhance the affirmation of such important entitlements as those affirmed in the R.R. and Costa and Pavan rulings, that is the right to access to the information that is decisive for exercising personal autonomy, with specific regard in the case to prenatal diagnosis, and the right to have a child unaffected by the disease of which the parents are healthy carriers. Incorporation of this view would also help to enhance the protection of abortion rights, with reference to the procedural guarantees that have to be ensured under Article 8 of the ECHR and which are already intended, in the Court's jurisprudence, as access

${ }^{247}$ See Cassetti, L., "La "Costruzione" dei Diritti Sociali nell'approccio della Corte Interamericana e della Corte Europea di Strasburgo: Contenuto, Limiti e Prospettive della "Comunicazione" Giurisprudenziale", Federalismi.it - Focus Human Rights, n. 2, 2014, pp. 1-23, 7.

${ }^{248}$ Interestingly, this approach of the IACtHR was defined in scholarship as "cherry picking", in light of the capacity and the intent of the Court to properly identify the references apt to enhance the protection ensured in an effective and targeted way. In this regard, see Groppi, T., Lecis Cocco Ortu, A.M., "Le citazioni reciproche tra la Corte Europea e la Corte Interamericana dei Diritti dell'Uomo: dall'influenza al dialogo?", cited above n. 166, p. 36.

${ }^{249}$ Case of Artavia Murillo et al. ("In vitro fertilization") v. Costa Rica, cited above n. 90, para. 146. 
to abortion in case a given State allows it. Of course, it seems very unlikely that it might ease the affirmation of abortion rights and access to abortion services in relation to the substantial limb of private life, as the Court's view on the beginning of life and its self-restrained approach are hard to change due to the lasting regional pluralism on the issue.

Despite the ECHR system does not contemplate any provision similar neither to Article 14 of the Protocol of San Salvador nor to Article XIII of the ADRDM, reference could be made to Article 15(1)(b) of the ICESCR consistently with the Article 31(3)(c) of the VCLT, as all States Parties to the ECHR are also Parties to the ICESCR ${ }^{250}$ Actually, the provision was already recalled in the Strasbourg case law in the Judges' Separate Opinions and with divergent reading of its content and its impact on the interpretation of conventional rights. In their Joint Dissenting Opinion in the case of S.H. and Others v. Austria, Judges Tulkens, Hirvelä, Lazarova Trajkovska and Tsotsoria, referred to Article 12(1), on the right of everyone to enjoy the highest standard of physical and mental health, and 15(1)(b) of the ICESCR, to clarify that "what is at stake here is not a question of choice between different techniques but, more fundamentally, a restriction on access to heterologous in vitro fertilisation constituting denial of access to available treatment". ${ }^{251}$ In a different vein, in the Parrillo case, in his Concurring Opinion, Judge Pinto de Albuquerque clarified that the "freedom [indispensable for scientific research protected under Article $15(1)(b)$ of the ICESCR] may be restricted in order to promote the "general welfare in a democratic society" and that, in particular, "[t]he protection of unborn human life as an indispensable social value in a democratic society, which concerns the welfare not only of present but also future generations, falls squarely within the restriction clause of Article 4 of the ICESCR [...]". ${ }^{252}$ Beyond the contextualization of the Judges' Separate Opinions, since the facts as well as the legal issues raised in the cases were different, it seems that the view expressed by Judge Pinto de Albuquerque can extend beyond the question of the donation of human embryos to research, providing guidance on the protection to be ensured to the unborn beyond the specific circumstances of the case, when the scientific progress is at stake before the ECtHR.

From the considerations made, it results all the more delicate but also important for the Strasbourg Court to make reference to the ICESCR. It could be possibly made through a combined reading of Article 12(1) and 15(1)(b) when dealing with reproductive rights and access to reproductive services, in a way that is consistent with the generally recognized core conception of

${ }^{250}$ All countries in the world are Parties to the ICESCR, except for Botswana, Brunei, Malaysia, Mozambique, South Sudan.

${ }^{251}$ S.H. and Others v. Austria, cited above n. 137, Joint Dissenting Opinion of Judges Tulkens, Hivelä, Lazarova Trajkovska and Tsotsoria, para. 9.

${ }^{252}$ Parrillo v. Italy, cited above n. 112, Concurring Opinion of Judge Pinto de Albuquerque, para. 2. 
reproductive rights. In this regard, the above-mentioned General Comment No. 22 (2016) would be a helpful reference for clarifying the content of States' duties under Article 12(1) of the Covenant, above all where it states that "[t]he failure or refusal to incorporate technological advancements and innovations in the provision of sexual and reproductive health services, such as medication for abortion, assisted reproductive technologies, and advancements in the treatment of HIV and AIDS, jeopardizes the quality of care". ${ }^{253}$ In this respect, this statement arguably seems to establish a fil rouge between the Article 12(1) and Article 15(1)(b) of the Covenant which ensure the protection of reproductive rights in relation to the techniques made available by scientific progress, although further precious guidance will only be offered by forthcoming General Comment on the right to science on Article 15(1)(b). What is more, it may also be argued that a similar approach, which underpins the Court's legal reasoning by reference to the relevant international landscape, would also help to shield the Strasbourg jurisprudence from States' interferences, which would help to prevent future "backward steps" as the one that the ECtHR took in the S.H. and Others v. Austria case.

That being said, keeping in mind that the IACtHR has had only two chances for expressing its view on reproductive rights, the achievements in San José are more advanced than those of the ECtHR. However, this promising first steps do not exclude that the IACtHR may benefit from the achievements of the ECtHR concerning the right to become genetic parents and, above all, prenatal diagnosis and PGD to strengthen its case law, in line with its usual approach. It is not surprising that, for example, in the Artavia Murillo judgment the IACtHR has recalled the ECtHR decisions in the Vo, A, B, C, Evans, S.H. and Others and Costa and Pavan judgments. ${ }^{254}$

Arguably, another feasible path may be suggested for the improvement of the Inter-American case law in the reproductive field. In fact, besides the provisions considered above, the ACHR contains also another suitable legal basis, namely Article 26 on "Progressive development", according to which "States Parties undertake to adopt measures [for achieving] full realization of the rights implicit in the economic, social, educational, scientific, and cultural standards set forth in the Charter of the Organization of American States". This provision, that the Court did not use in the Artavia Murillo judgment, is

${ }^{253}$ UN Committee on Economic, Social and Cultural Rights, General comment No. 22 (2016) on the right to sexual and reproductive health (article 12 of the International Covenant on Economic, Social and Cultural Rights), cited above n. 88, para. 21. The '4-A scheme' hinges on availability, accessibility, acceptability and adaptability which turns into quality when health is at stake and has helped to elucidate the content of States' duties under the Covenant.

${ }^{254}$ These references, that were recalled at paras. 237-242 as relevant international references from the ECHR system can be found incorporated in the legal reasoning of the Court various times. More specifically, for instance, the Vo, S.H. and Others and Costa and Pavan rulings were recalled when the IACtHR dealt with the legal status of the embryo.

Araucaria. Revista Iberoamericana de Filosofia, Política, Humanidades y Relaciones Internacionales, año 20, $\mathrm{n}^{\circ} 40$. Segundo semestre de 2018. Pp. 655-732. ISSN 1575-6823 e-ISSN 2340-2199 doi: 10.12795/araucaria.2018.i40.27 
interesting from several viewpoints. Primarily, because it may arguably offer some protection to sexual and reproductive health even with respect to those States that are not Parties to the Protocol of San Salvador and, thus, are not bound to Article 14 thereof. What is more, it seems interesting to consider the kind of scrutiny that Article 26 of the ACHR would allow to the IACtHR in the field of reproductive rights. It may be advanced, that the Court would benefit from the use of this provision since it recalls the Charter of the OAS, which makes specific reference to scientific and technological progress in relation to the integral development for the peoples of the Member States of the OAS. This is of basic importance as scientific progress is intended in relation to the protection of man's potential and as a foundation of social justice. This would arguably help to affirm some guarantees under the ACHR in relation to the achievements of scientific progress in the field of reproduction and that such achievement should not be exclusive, but generally accessible. Furthermore, reference to Article 26 would allow the Court to scrutinize States' compliance with the duty of non-regression, that here would imply to ensure the progressive development of the protection of reproductive and sexual health and rights also through adequate allocation of resources. Arguably, use of Article 26 of the ACHR would require some efforts to the Court as, so far, this provision has been used beneath its potential; 255 its use seems desirable as it would be helpful to promote the access to advanced medical reproductive technology through appropriate States funding.

The ECHR system does not contain any comparable provision; nevertheless, some interesting reference is offered by the Oviedo Convention that, at Article 3, foresees States' duty to ensure "equitable access to health care of appropriate quality", according to health needs and to the resources available. This could be used as a support to the interpretation by the Strasbourg Court of the obligations under the ECHR. Clearly, the impact of this provision is different from Article 26 of the ACHR: not all States Parties to the ECHR are also Parties to the Oviedo Convention and its scope does not expressly encompass scientific progress. Nonetheless, the standard of quality could be intended as encompassing a full understanding of health and health care, according to the generally accepted notion of sexual and reproductive health and reproductive rights.

That being said, it could be questioned whether some further development may be expected in the case law of the ECtHR and the IACtHR with particular reference to the most advanced reproductive achievements that scientific

255 Inter-American Court of Human Rights, Case of Five Pensioners v Peru, Judgment of 28 February 2003, Merits, Reparations and Costs, Series C No. 98. See: CASSETTI, L., "La "Costruzione" dei Diritti Sociali nell'approccio della Corte Interamericana e della Corte Europea di Strasburgo: Contenuto, Limiti e Prospettive della "Comunicazione" Giurisprudenziale", cited above n. 246.

Araucaria. Revista Iberoamericana de Filosofia, Política, Humanidades y Relaciones Internacionales, año 20, ${ }^{\circ} 40$. Segundo semestre de 2018. Pp. 655-732. ISSN 1575-6823 e-ISSN 2340-2199 doi: 10.12795/araucaria.2018.i40.27 
progress is making available and which need an adequate legal response, as law always "lag behind science". ${ }^{256}$ Reference here is made in particular to genome editing and its possible therapeutic applications concerning human embryos in the field of reproduction, seeking solutions capable of framing scientific evolution in the human rights discourse related to reproduction that, at the same time, are respectful of the unborn. Next paragraph, then, explores the viability of a human rights-based approach for ensuring accessibility to such biomedical and biotechnological opportunities and, for this purpose, it assesses which paths are allowed under international law and might be incorporated, even if not immediately, in the generally accepted core conception of reproductive and sexual health and reproductive rights.

\section{Scientific progress and reproduction: viability of a human rights- based approach before the ECtHR and the IACtHR}

The evolution of scientific progress and the innovative applications that it offers and that might suit important reproductive needs and wishes, pose huge challenges to international human rights law and in particular to such major regional Courts as the ECtHR and the IACtHR. Indeed, biomedicine, biotechnology and genetic engineering are in constant evolution and already offer prodigious means, which have culminated with the achievement of the CRISPR-Cas9, a technique that, as anticipated, even allows to edit the human germline.

The ways in which scientific progress and its achievements can intertwine with reproductive rights are various: of course, they concern human germline editing. The eugenic risks are evident and human germline editing is a particularly debated question: since it affects the oocyte, sperm and early embryo, it entails alterations that are transmissible to the descendants. This is the feature which distinguishes it from human somatic cells alterations, that affect body cells and, thus, concern only the subject treated. Human germline alterations may be carried out for two distinct purposes, namely for therapeutic ends or for human enhancement. ${ }^{257}$ Focusing on therapeutic modifications, different kinds of interventions are now available and they range, just to mention some possibilities, from the replacement of an altered gene to fixing

\footnotetext{
${ }^{256}$ García San José, D. I., International Bio Law. An International Overview of Developments in Human Embryo Research and Experimentation, cited above n. 10, 149, 164, 179, 189, 192.

${ }^{257}$ In practice, it is not always easy to distinguish the two kinds of interventions. The criterion of "normality" was advanced as the standard for identifying "therapeutic" interventions of genome editing, which entail "corrective" interventions on the genome, in order to prevent the onset of genetic diseases. Enhancing alterations, instead, are intended to bring about an improvement of some traits of the subject treated, even when no pathological exigency requires it. For example, for increasing the intellectual capacity of an individual.
} 
up such alterations. The research carried out by the Chinese scientists in order to repair the genetic mutation causing beta-thalassemia is a paradigmatic example. ${ }^{258}$ Another interesting scientific achievement is represented by mitochondrial replacement techniques (MRTs), which can help to prevent the onset of genetic diseases transmissible from the mother to the child and which was allowed in 2015 in the United Kingdom. ${ }^{259}$ This preserves the genetic kinship between the couple and the child and, at the same time, it prevents the baby from developing a specific genetic disease. These techniques may also be a precious means for female same-sex couples, as they would make possible for the mothers to have a child that is genetically related to both of them. These techniques go beyond the possibilities offered by preimplantation genetic diagnosis (PGD) and preimplantation genetic screening (PGS) ${ }^{260}$ which do not imply human germline alterations but allow the implantation of the "healthy" embryos, and beyond prenatal diagnosis on the foetus, which is carried out after implantation. ${ }^{261}$ It appears quite evident how all these interesting practices and

${ }^{258}$ Cyranoski, D., Reardon, S., "Chinese scientists genetically modify human embryos. Rumours of germline modification prove true - and look set to reignite an ethical debate", Nature, 22 April 2005, available at https://www.nature.com/news/chinese-scientists-genetically-modify-humanembryos-1.17378 last visited 14 July 2018.

${ }_{259}$ In practice, MRTs allow replacing the mother's mitochondrial DNA with the one from a woman donor. ORCUT, M., "The Unintended Consequence of Congress's Ban on Designer Babies. The testing of new therapies to prevent a debilitating mitochondrial genetic disease in babies has hit a dead end", MIT Technology Review, 26 August 2016, available at https://www.technologyreview.com/s/602219/ the-unintended-consequence-of-congresss-ban-on-designer-babies/ last visited 14 July 2018.

${ }^{260}$ Rodotà, S., Trattato di Biodiritto, $l l$ Governo del Corpo, p. 381. The preimplantation diagnostic screening is performed when the couple has no specific indication as to the possibility to bear a child affected by a genetic disease, but some peculiar conditions might expose the parents to this possibility due to such particular conditions as the advanced age of the mother, serial miscarriage and severe male factor infertility.

${ }^{261}$ However, under some circumstances PGD and PGS cannot be helpful, for instance with respect to dominant late-onset genetic diseases, such as Huntington's disease, or in those cases where a given genetic disease-causing mutation is widely spread in the population, as for instance the tumor suppressor genes BRCA1 and BRCA2, which increase the risk of developing breast and ovarian cancer even when inherited in a single copy (because of loss of the unaffected copy of the gene), the Tay-Sachs disease and other early-onset lysosomal storage diseases caused by the inheritance of two copies of recessive mutations. Another limitation that, in general, concerns these diagnostic techniques is that they can provide information about the genotype, but not about the phenotype, therefore they offer no indication about how the genetic heritage of an embryo will interact with the environment in the future and the epigenetic evolution it might get through. National Academies of Sciences, Engineering, and Medicine, Human Genome Editing: Science, Ethics and Governance, Washington, The National Academies Press, 2017. Another interesting practice, which goes beyond the scope of this paper, is represented by the "saviour siblings". In this case, PGD techniques and ARTs are used for the identification and implantation of an embryo that is viable for curing the diseases from which some close relatives, especially sibling, are affected. For example, with regard to human leukocyte antigen (HLA) compatible siblings, that may help to treat their brothers or sisters through allogeneic haematopoietic stem cell transplantation with reference to various congenital diseases, as beta-thalassemia, by using the cells taken from the umbilical cordon or through spinal cord transplant. Scientific progress is currently attempting to devise also the alternative route of gametes genome editing, that is the modification of the genome of eggs and sperm which, would allow preselection of targeted gametes in vitro before fertilization and implantation of the embryo. So far, this technique

Araucaria. Revista Iberoamericana de Filosofía, Política, Humanidades y Relaciones Internacionales, año 20, $\mathrm{n}^{\circ} 40$. Segundo semestre de 2018. Pp. 655-732. ISSN 1575-6823 e-ISSN 2340-2199 doi: 10.12795/araucaria.2018.i40.27 
achievements may benefit reproductive rights but they might importantly affect the unborn, thus their compatibility with international law and their framing within human rights law requires to be assessed.

Very few instruments contain pertinent provisions in this respect. The relevant references are offered by the Oviedo Convention ${ }^{262}$ and by the UNESCO Universal Declaration on Human Genome and Human Rights (UNESCO UDHGHR). ${ }^{263}$ Both instrument build upon the principle of human dignity, which represents the ultimate bioethical principle from which the protection of fundamental rights flows ${ }^{264}$ and which should be preserved from the risks of eugenics and the distorted applications of scientific progress. In this regard, the UNESCO UDHGHR expressly holds that "everyone has a right to respect for their dignity and for their rights regardless of their genetic characteristics" at Article 2(a) and the Oviedo Convention, in its Preamble, recalls " the need to respect the human being both as an individual and as a member of the human species and recognis[es] the importance of ensuring the dignity of the human being", that might be endangered by the "misuse of biology and medicine". As seen in paragraph two, human dignity is identified by a huge part of constitutional jurisprudence worldwide as the founding value that justifies the protection to be granted to the "potential of life" that the unborn enshrines, even if personhood and, thus, the bearing of the right to life are excluded. The protection of human dignity is the essential point of the relevant provisions which can offer guidance for assessing feasibility of the use of advanced scientific applications in the field of reproductive rights, respectful of the unborn. In this regard, the protection of the unborn and its dignity from the "misuse of biology and medicine" can be intended, with reference to both instruments, in relation the duty of mankind to protect future generations and the principle of responsibility, which in scholarship was a pillar of the philosophy of Hans Jonas, who claimed that human nature has to be

is experimental on mice and several other mammals, importantly including non-human primates as well, but there is still a long way to go for mainstreaming it for humans. Baetens, P., Van De Velde, H., Camus, M., Pennings, G., Van Steirteghem, A., Devroey, P., Liebaers, I., "HLA-matched embryos selected for siblings requiring haematopoietic stem cell transplantation: a psychological perspective", Reproductive Biomedicine Online, $\mathrm{n}^{\circ}$ 10(2), (February 2005), pp. 154-163. Rodotà, S., Trattato di Biodiritto, ll Governo del Corpo, p. 381.

${ }^{262}$ Council of Europe, Convention for the protection of Human Rights and Dignity of the Human Being with regard to the Application of Biology and Medicine: Convention on Human Rights and Biomedicine (adopted 4 April 1997, entered into force 1 December 1999), ETS No. 164, available at https://rm.coe.int/168007cf98 last accessed 3 July 2018.

${ }^{263}$ UN Educational, Scientific and Cultural Organisation (UNESCO), Universal Declaration on the Human Genome and Human Rights, 11 November 1997, Adopted unanimously and by acclamation by the General Conference of UNESCO at its 29th session on 11 November 1997, available at http:// portal.unesco.org/en/ev.php-URL_ID=13177\&URL_DO=DO_TOPIC\&URL_SECTION=201.html last accessed 3 July 2018.

264 See Andorno, R., "Biomedicine and international human rights law: in search of a global consensus", Bulletin of the World Health Organization, n 80, 2002, pp. 959-963, 960. 
preserved at all costs. ${ }^{265}$ In this regard, when the protection of the descendants is at stake, human germline modifications, either concerning the gametes or the human embryos require thorough consideration, especially because of the intergenerational and transgenerational transmissibility of these alterations, which may clash with the principles under consideration. Indeed, as clarified by the Explanatory Report of the Oviedo Convention, "the developments in medicine and biology [...] should be used only for the benefit of present and future generations and not be diverted in ways that run counter to their proper objective", as scientific progress has to serve always the "benefits of progress to the whole of mankind". ${ }^{266}$ Importantly, this statement is echoed by Paragraph 89 concerning Article 13 of the Oviedo Convention ${ }^{267}$ which provides that "[a] $\mathrm{n}$ intervention seeking to modify the human genome may only be undertaken for preventive, diagnostic or therapeutic purposes and only if its aim is not to introduce any modification in the genome of any descendants", a view that is specified and complemented by Paragraph 91 of the Explanatory Report where it stresses that "[c]onsequently, in particular genetic modifications of spermatozoa or ova for fertilisation are not allowed". Similarly, the UNESCO UDHGHR, at Article 12(b), provides that "that the application of research "shall seek to offer relief from suffering and improve the health of individuals and humankind as a whole" and, at Article 24, explicitly qualifies human germline alterations as a practice contrary to human dignity. ${ }^{268}$ The UNESCO and the $\mathrm{COE}^{269}$ recently have restated their reluctancy about human germline editing, ${ }^{270}$

265 Jonas, H., The Imperative of Reponsibility - In Search of an Ethics for the Technological Age, Chicago, London, The University of Chicago Press, 1984. Also see: MORRIS, T., Hans Jonas's Ethic of Responsibility: From Ontology to Ecology, Albany, State University of New York Press, 2013.

266 Explanatory Report to Convention for the protection of Human Rights and Dignity of the Human Being with regard to the Application of Biology and Medicine: Convention on Human Rights and Biomedicine, Oviedo, 4 April 1997, ETS No. 164, Paragraph 15.

${ }^{267}$ In particular, Paragraph 89 of the Explanatory Report, concerning Article 13 of the Oviedo Convention on the interventions on human genome, stresses that "developments in th[e] field [of human genome editing] may lead to great benefit for humanity, misuse of these developments may endanger not only the individual but the species itself".

268 It seems relevant to recall here the conception, in a symbolic sense, of the human genome as "heritage of mankind" contained in Article 1 of the UNESCO Declaration embodies the concerns but also the hopes of the international community and of the scientific community, that also led to the Joint Statement of 14 March 2000 of the then President of the United States of America Bill Clinton and the then British Prime Minister Tony Blair, which claimed that "fundamental data on the human genome, including the human DNA sequence and its variations, should be made freely available to scientists everywhere". The possibility to access freely to the "fundamental data on the human genome" is instrumentally linked to the "benefit of mankind" and the beneficial results which, for that purpose, scientific progress may achieve. Of course, the reproductive field is no exception in this sense.

269 Council of Europe, Parliamentary Assembly, Recommendation 2115(2017) on "The use of new genetic technologies in human beings", Assembly debate on 12 October 2017 (35th Sitting) (see Doc. 14328, report of the Committee on Social Affairs, Health and Sustainable Development, rapporteur: Ms Petra De Sutter). Text adopted by the Assembly on 12 October 2017 (35th Sitting), available at http://assembly.coe.int/nw/xml/XRef/Xref-XML2HTML-EN.asp?fileid=24228\&lang=en last visited 14 July 2018.

270 Council of Europe, Committee on Bioethics, "Statement on genome editing technologies", $8^{\text {th }}$ Segundo semestre de 2018. Pp. 655-732. ISSN 1575-6823 e-ISSN 2340-2199 doi: 10.12795/araucaria.2018.i40.27 
Human Rights and the European Court of Human Rights

inviting States to take a wise and cautious approach to the advanced techniques offered by scientific progress and making explicit reference to the eugenic risks related to reproduction. What is more, so far the prohibition of human germline alterations, together with the ban on reproductive cloning, is one of the two biolegal practices about which the international community has expressed its consensus. ${ }^{271}$ Therefore, under the instruments considered and according to the international view emerged so far, the unborn would receive absolute protection from any modification of its human germline; correspondingly, no room for the affirmation of the reproductive rights concerning access to the advanced techniques mentioned above would seem to be left under the Oviedo Convention and the UNESCO UDHGHR. However, some scholars and some scientists have begun to suggest a different viewpoint, that would entail the reconsideration of the rigour of the prohibition. ${ }^{272}$ What is more, the UNESCO and the COE themselves although restating their reluctance, have recognized that the ethical debate on human germline alterations is still open ${ }^{273}$ and that some techniques, as MRTs, were used "despite the considerable ethical controversy and scientific uncertainty about the long-term effects". ${ }^{274}$

Meeting, 1-4 December 2015, available at https://rm.coe.int/168049034a last accessed 14 July 2018. Further information available at https://www.coe.int/en/web/bioethics/-/gene-editing?desktop=true last visited 14 July 2018. In particular, it seems interesting to stress that the Committee on Bioethics of the COE declared to be "convinced that the Oviedo Convention provides principles that could be used as reference for the debate called for at international level on the fundamental questions raised by these recent technological developments". UNESCO, International Bioethics Committee, Report of the IBC on Updating Its Reflection on Human Genome and Human Rights, SHS/YES/IBC-22/15/2 REV.2, Paris, 2 October 2015, available at http://unesdoc.unesco.org/images/0023/002332/233258E.pdf last accessed 15 July 2018. In particular, the Report of the UNESCO International Bioethics Committee called for a moratorium on human germline alterations due to the still uncertain results of this kind of modifications, "at least as long as the safety and efficacy of the procedures are not adequately proven as treatments". This statement might leave some margin of manoeuvre to the possibility to reconsider human germline editing as a viable path when it becomes safer and more effective as "treatments", including in the field of reproduction. In Recommendation 2115 (2017), the COE expressly "urge[d] member States [to] ratif[y] the Oviedo Convention [...] or [...] to put in place a national ban on establishing a pregnancy with germ-line cells or human embryos having undergone intentional genome editing". However, it also gave recognition to the fact that some countries allow MRTs and that amendment of the Oviedo Convention is possible after appropriate debate according to Article 28 thereof, in light of the developments of biology and medicine.

271 In this regard, it is indicative that the UNESCO Universal Declaration on Human Genome and Human Rights was endorsed unanimously by the General Assembly.

272 In late 2015, the Organizing Committee for the International Summit on Human Gene Editing, in which outstanding researchers in the field participated, published a summit statement where it did not exclude running in-vitro human germline genetic interventions. Some other scientists joined the debate arguing that in-vitro research implying human germline editing may be a feasible route. See: HARRIS, J., Enhancing evolution. The ethical case for making better people, Princeton, Princeton University Press, 2007; Gomes De Andrade, N. N., "Human Genetic Manipulation and the Right to Identity: the Contradictions of Human Rights Law in Regulating the Human Genome", SCRIPTed, Volume 7, Issue 3, December 2010, pp. 429-452, 432-433,437; GUNDERSON, M., "Enhancing Human Rights: How the Use of Human Rights Treaties to Prohibit Genetic Engineering Weakens Human Rights", Journal of Evolution and Technology, vol. 18(1), (2008), pp. 27-34.

273 UNESCO, International Bioethics Committee, Report of the IBC on Updating Its Reflection on Human Genome and Human Rights, cited above n. 269, para. 118.

${ }^{274}$ Council of Europe, Recommendation 2115 (2017), cited above n. 269, para. 2. 
Thus, it should be questioned whether a redefinition of this view may be desirable and expectable, especially in light of the benefits to the health of the unborn and of future generations that scientific progress has made possible in the last twenty years after the adoption of the instruments under consideration, and whether access to these advanced outcomes of scientific progress may be theorized as a component of reproductive rights from an evolutionary viewpoint.

A key conception, for this purpose, is represented by the restricted notion of the right to genetic identity, ${ }^{275}$ which is related to the protection of human dignity. As held in scholarship, the restricted notion of this entitlement would encompass only core personal traits ${ }^{276}$ and, thus, would allow human germline alterations for therapeutic purposes, but not those aimed at enhancement. ${ }^{277}$ In this respect, the concept of genetic "identity" should not be overlapped with the conception of genetic "integrity", that implies the right to a non-modified genetic heritage. In scholarship, it was highlighted that "it is important to understand that not every intervention on the human genome aimed at modifying the germline necessarily equates to an eugenic practice" and that "the right to genetic integrity is no longer formulated in terms of a general right to a nonmodified genetic heritage or as an equivalent of a right to genetic identity". This emerges in international human rights law too and a remarkable example is offered by Article 3 of the Charter of Fundamental Rights of the European

${ }^{275}$ Genetic identity and genetic integrity are two important conceptions with regard to genome editing: an interesting reading was advanced in scholarship with regard to genome alterations in adult subjects, which were justified by the right to genetic identity as a reaffirmation of the individual sphere against the genetic integrity of human species, that would hamper genetic alterations. See Gomes De Andrade, N. N., "Human Genetic Manipulation and the Right to Identity: the Contradictions of Human Rights Law in Regulating the Human Genome", cited above n. 271.

276 A specification should be made about the conception of genetic identity, that is closely related to human dignity. The main reasons are that present generation do not have the right to genetically predetermine genetic characteristics of future generation according to their contingent conception of what is "good" or what is "bad". Moreover, future generations might perceive themselves as mere objects due to such alterations. See Andorno, R., "Biomedicine and international human rights law: in search of a global consensus", cited above n. 63, p. 961. The extreme result of this perspective is that alteration in human germline might amount to crimes against humanity. (in this regard, see Annas, G. J., Andrews, L. B., Isasi, R. M., "Protecting the endangered human: Toward an international treaty prohibiting cloning and inheritable alterations", American Journal of Law and Medicine, 28(2-3), (2002), pp. 151-178. The concerns are so serious that it was advanced the idea to adopt a "Convention on the Preservation of the Human Species". In this sense, see Gunderson, M., "Enhancing Human Rights: How the Use of Human Rights Treaties to Prohibit Genetic Engineering Weakens Human Rights", cited above n. 271.

${ }^{277}$ In this regard, it is not at odds with the fact that therapeutic interventions also determine an enhancement of the human conditions, as far as it concerns health, as clarified by John Harris. Harris, J., Enhancing evolution. The ethical case for making better people, cited above n. 271. Of course, also opposite views were authoritatively expressed. For example, Jürgen Habermas and Michael Sandel rule out any modification, basically respectively in the name of an "anthropologic universality" and for the risk to compromise such founding human and social values as humility, responsibility and solidarity”. See: Sandel, M., Contro la perfezione, Milano, Vita e Pensiero, 2008; Habermas, J., Il futuro della natura umana. I rischi di una genetica liberale, Torino, Einaudi, 2002; 
Human Rights and the European Court of Human Rights

Union (CFR), which recalls as an example of eugenic practices those aimed at the selection of persons and which makes reference also to reproductive cloning but does not mention human germline alterations. Again, with even wider consequences, scholarship has highlighted that the conception of human dignity embraced by the CFR refers to any born person, thus it does not concern pre-natal life, as can be inferred from the fact that the Charter, in Title I on "Dignity", incorporated the prohibition on human cloning in Article 3, on the right to integrity, and not in Article 2, on the right to life. ${ }^{278}$ Interestingly, it was additionally held that " $[\mathrm{t}]$ he association of the right to genetic integrity $[\ldots]$ with the right to genetic identity [...] focuses solely upon the perils of the [genetic manipulation] latter without considering the potential benefits that can be derived from human genetic interventions" and that " $[t]$ he right to genetic identity, therefore, should both foresee the integrity but also the changeability of one's genetic architecture."279

The possibility to rely on preventive and therapeutic human germline alterations in the reproductive field should all the more be reconsidered according to those scholars that have clarified that genetic identity, our authenticity and our

${ }^{278}$ As stated above, some interpretive guidance on the scope of integrity may be inferred from Article 3 of the Charter of Fundamental Rights of the European Union (CFR) where it prohibits eugenic practices such as "those aimed at the selection of persons". See: European Union: Council of the European Union, Charter of Fundamental Rights of the European Union (2007/C 303/01) (adopted 14 December 2007, entered into force 14 December 2007) C 303/1, available at http://www.europarl. europa.eu/charter/pdf/text_en.pdf last accessed 15 July 2018. In scholarship, see Gomes De Andrade, N. N., "Human Genetic Manipulation and the Right to Identity: the Contradictions of Human Rights Law in Regulating the Human Genome", cited above n. 271, p. 437. On the conception of human dignity under the CFR see: García San José, D. I., European Normative Framework for Biomedical Research in Human Embryos, cited above n. 10, pp. 99-100. GARCÍA SAN JOSÉ, D. I., "Derecho de la Unión, Investigación embrionaria humana y patentes biológicas", Revista de Derecho Comunitario Europeo, Madrid, n 41, enero/abril, 2012, pp. 161-180, $175 \mathrm{ff}$.

${ }^{279}$ The whole quotation reads: "[It] is important to understand that not every intervention on the human genome aimed at modifying the germline necessarily equates to an eugenic practice. Therefore, it is more appropriate to follow the drafting example of the Charter of Fundamental Rights of the European Union's art 3, "Right to the integrity of the person", which unlike the Oviedo Convention, does not enshrine any general prohibition of germline genetic modifications. Art 3, refers instead to the prohibition of eugenic practices (in particular those aiming at the selection of persons) specifically and to the reproductive cloning of human beings (art 3.2). Contrary to the initiatives in the 1980s and 1990s led by European institutions, the right to genetic integrity is no longer formulated in terms of a general right to a non-modified genetic heritage or as an equivalent of a right to genetic identity. The association of the right to genetic integrity (and, subsequently, the right to a non-modified genetic heritage) with the right to genetic identity constitutes an old fashioned, narrow and detrimental view of human genetic manipulation, which focuses solely upon the perils of the latter without considering the potential benefits that can be derived from human genetic interventions. The right to genetic identity, therefore, should both foresee the integrity but also the changeability of one's genetic architecture: the right to personal identity may perfectly encompass the right to individual genetic modification." Gomes De Andrade, N. N., "Human Genetic Manipulation and the Right to Identity: the Contradictions of Human Rights Law in Regulating the Human Genome", cited above n. 271, p. 437. Also see, in particular, pp. 432-433. Moreover, the individual genetic identity and integrity should not be overlapped with the genetic identity and integrity of the species. 
uniqueness should not "spawn a human right"280 like, arguably, the enjoyment of reproductive rights in relation the benefits of scientific progress. ${ }^{281}$ What is more, the prevention of the onset of a genetic disease does not seem to be at odds with human dignity; otherwise, the protection of the unborn from possible future suffering seems to be coherent with this rationale. ${ }^{282}$ In particular, it does not seems to be qualifiable as a "misuse of biology and medicine" capable of endangering the "dignity of the human being" and the "potential of life" that characterizes the unborn as constitutional jurisprudence has stressed in various countries. Again, this view would arguably be consistent with the Oviedo Convention, in particular as Paragraph 90 of the Explanatory Report clarifies that "any intervention which aims to modify the human genome must be carried out for preventive, diagnostic or therapeutic purposes" and that "[i] nterventions aimed at modifying genetic characteristics not related to a disease or to an ailment are prohibited".

What is more, viability of human germline modifications for therapeutic purposes might be reconciled with Article 14 of the Oviedo Convention, which prohibits the selection of the future's child sex "except where serious hereditary sex-related disease is to be avoided". Then, this provision might also be read as leaving some margin to therapeutic interventions on human embryos in the context of assisted reproductive technology, which also seems all the more arguable when one considers that authoritative scholarship affirms the right to be born with dignity, ${ }^{283}$ whose scope may encompass therapeutic interventions. ${ }^{284}$ Moreover, the issue of the lack of consent of the unborn might be dealt with as for "children who are too young to consent for themselves". ${ }^{285}$

That being said, once the possibility to advance the reconsideration of the prohibition of the use of preventive and therapeutic human germline modifications in the field reproduction is taken into account, it should be assessed whether and how it could be framed in the human rights discourse for

${ }^{280}$ Annas, G. J., Andrews, L. B., Isasi, R. M., "Protecting the endangered human: Toward an international treaty prohibiting cloning and inheritable alterations", cited above n. 275 .

281 Häyry, M., "Another look at dignity", Cambridge quarterly of healthcare ethics, $\mathrm{n}^{\circ} 13(1)$, (2204), pp. 7-14.

${ }^{282}$ Netherlands Commission on Genetic Modification (COGEM), Health Council of the Netherlands (Gezondheidsraad),

"Editing Human DNA: Moral and social implications of germline genetic modification", Bilthoven, the Netherlands, COGEM, 2017; Nuffield Council on Bioethics, "Genome Editing and Human Reproduction: social and ethical issues", London, Nuffield Council on Bioethics, 2018.

${ }^{283}$ In fact, although the right to be born with dignity requires due self-restraint when approached, therapeutic purposes stands out, as "nobody would disagree in principle with therapies for treatment of diseases". García San José, D.I., International Bio Law. An International Overview of Developments in Human Embryo Research and Experimentation, cited above n. 10, p. 53.

${ }^{284}$ Moreover, this would seem in line with the principle of human dignity intended in the Kantian sense that no one - neither the unborn - should be used as a mean but as an end, as the aim would be the improvement of the health of the unborn itself.

285 In this regard, see Chadwick, R., "Gene Therapy", in A Companion to Bioethics, Kuhse, H., Singer, P. (eds.), Hoboken, Wiley-Blackwell, 1998, pp. 205-215, 209.

Araucaria. Revista Iberoamericana de Filosofia, Política, Humanidades y Relaciones Internacionales, año $20, \mathrm{n}^{\circ} 40$. Segundo semestre de 2018. Pp. 655-732. ISSN 1575-6823 e-ISSN 2340-2199 doi: 10.12795/araucaria.2018.i40.27 
the purpose of analysing its incorporation in the jurisprudence of the ECtHR and of the IACtHR. In particular, it should be assessed whether and how this view might complement the core conception of reproductive rights that has found general acceptance under international law and which already includes such techniques as ARTs and IVF, as stated above. This may be suggested as a feasible path for fostering jurisprudential "rejuvenation" in light of relentless reproductive - scientific progress.

In this regard, it still seems early to affirm the incorporation of the right to access and enjoy these technologies into the generally accepted conception of reproductive and sexual health and reproductive rights. Currently specific indications in this sense still lack, in part due to the fact that some techniques are still at an experimental stage and practice at the moment has not given the chance to express their view to international judicial and non-judicial human rights bodies, whose jurisprudence has played a fundamental role for making the core conception of reproductive health and rights keep the pace with time. Inclusion of ARTs and IVF is indicative in this sense and helps to argue that also therapeutic human germline editing may be incorporated in this conception in the future. It is arguable also because the relevant human rights bases seem capable of including it and, which concerns us more closely, also of making feasible its incorporation in the case law of the ECtHR and of the IACtHR.

Once again, for the IACtHR it would be an easier task, as suitable legal bases can be sought in the Inter-American Human Rights system, namely the above-mentioned Article 18 of the Protocol of San Salvador and Article XIII of the American Declaration. This seems particularly true in light of the proactive interpretation that the Court has given to these provisions, also by relying on the principle pro persona. In fact, the IACtHR has held that "in keeping with Article 29(b) of the American Convention, the scope of the rights to private life, reproductive autonomy and to found a family $[\ldots]$ extends to the right of everyone to benefit from scientific progress and its applications" and that " $[t]$ he right to have access to scientific progress in order to exercise reproductive autonomy and the possibility to found a family gives rise to the right to have access to the best health care services in assisted reproduction techniques ${ }^{286 "}{ }^{287}$ Arguably, most advanced techniques available may be considered to be encompassed in the notion as best health care services in the field of reproduction.

In a similar vein, an appropriate legal basis can be sought, at the universal level, in Article 12 of the ICESCR, as read by the Committee on Economic, Social and Cultural Rights in General Comment No. 22 (2016). So far, the Committee has not included therapeutic human germline alterations in the

${ }^{286}$ Emphasis added.

${ }^{287}$ Case of Artavia Murillo et al. ("In vitro fertilization") v. Costa Rica, cited above n. 90, para. 150. 
field of reproduction within the scope of the right to health and the right to the highest attainable standards of health, although the conception of quality ${ }^{288}$ as incorporation of "technological advances and innovations in the provision of sexual and reproductive health services" 289 seems a promising statement. In the future, this understanding of the entitlement may arguably be capable of encompassing also the techniques under consideration within its scope.

Last but not least, a particularly suitable legal basis seems to be offered by Article 15(1)(b) of the ICESCR, since the provision may encompass the enjoyment of the advanced techniques of genome editing as a therapeutic means for improving the health of the offsprings and preventing them from suffering from a given genetic disease. This is arguable because according to this provision States are under an obligation to ensure that "everyone [...] enjoy[s] the benefits of scientific progress and its applications". The scope of this entitlement may be interpreted more specifically by making reference to Article 27 of the UDHR, which is the archetype of UN human rights treaties. Article 27 provides that everyone has the rights to "share in scientific advancement and its benefits" which, through reference to the verbs "participer" and "participar" respectively used in the French and Spanish version of the UDHR, should be intended as the right to actively participate in scientific progress and its benefits. ${ }^{290}$ Including access to therapeutic human germline alterations in the field of reproduction within the scope of the provision seems all the more arguable when one additionally considers that States are under an obligation to take all the steps to achieve the "full realization" of this rights, "includ[ing] those necessary for the conservation, the development and the diffusion of science", pursuant to Article 15(2) of the ICESCR. So far, the Committee on Economic, Social and Cultural Rights has not expressed its view on the right to enjoy the benefits of scientific progress and, as anticipated above, there are great expectations about the General Comment of the right to science, which is going to be issued soon, in order to have some guidance. The view advanced seems all the more arguable if we consider that the 1997 UNESCO UDHGHR says that "benefits from advances in biology, genetics and medicine, concerning the human genome, shall be made available to

288 See: Donders, Y., The right to enjoy the benefits of scientific progress: in search of state obligations in relation to health, Medicine, Health Care, and Philosophy, ${ }^{\circ} 14(4)$, (November 2011), pp. 371-381.

${ }^{289}$ UN Committee on Economic, Social and Cultural Rights, General comment No. 22 (2016) on the right to sexual and reproductive health (article 12 of the International Covenant on Economic, Social and Cultural Rights), cited above n. 88, para. 21.

${ }^{290}$ Mancisidor, M., "Is There Such a Thing as a Human Right to Science in International Law? ", ESIL Reflections, ${ }^{\circ}$ 4(1), (7 April 2015), available at http://www.esil-sedi.eu/node/896 last visited 13 July 2018; Mancisidor, M., "Historia del Derecho Humano a la Ciencia", in Die Subversive Kraft der Menchenrechte, Huhle, N., Huhle, T., (eds.), Oldenburg, Paulo Freire Verlag, 2015. For further views and assessments on human rights in general and, in particular, on the right to science, it may also be interesting to visit the blog of Professor Mikel Mancisidor at http://mikelmancisidor.blogspot.it/.

Araucaria. Revista Iberoamericana de Filosofía, Política, Humanidades y Relaciones Internacionales, año 20, $\mathrm{n}^{\circ} 40$. Segundo semestre de 2018. Pp. 655-732. ISSN 1575-6823 e-ISSN 2340-2199 doi: 10.12795/araucaria.2018.i40.27 
all". ${ }^{291}$ In this regard, for having some clarification on how the conception of "benefit sharing" 292 may be intended at the international level, Article 19 of the UNESCO Universal Declaration on Human Genetic Data ${ }^{293}$ may offer an interesting reference where it provides that "benefits [...] should be shared with the society as a whole and the international community", a principle to which States shall provide effectiveness by ensuring "provision of new diagnostics, facilities for new treatments or drugs stemming from the research" besides "support to health services". If this view is applied to our reflections, it may arguably suggest that the innovative reproductive techniques made available through human germline editing could be considered as benefits to be shared.

Of course, both the ECtHR and the IACtHR would benefit from incorporation of such standards in their case law when dealing with reproductive rights, in line with the usual and established approach of the IACtHR and with some more efforts for the Strasbourg Court for using these references as a support for the interpretation of conventional duties under the ECHR in line with Article 31(3)(c) of the VCLT. Maybe we cannot expect this to happen immediately, but relentless scientific progress requires to consider paths of jurisprudential "rejuvenation" as soon as possible, in order to not to be unprepared in front of the challenges posed by medical and biological evolution.

\section{Conclusions}

The definition of the interplay between the protection of the unborn and reproductive rights represents a challenging issue for international human rights jurisprudence, and has been tackled on several occasions by both judicial and non-judicial human rights bodies.

Beyond reflecting the nature of reproductive rights as not "independent rights", the international jurisprudence has also contributed, along with the relevant soft law sources, to promote and highlight the existence of a core conception of sexual and reproductive health and reproductive rights that has received generalized acceptance at the international level, and which has proven capable of encompassing the achievements of scientific progress in the reproductive field, as ARTs and IVF.

This has not been an easy task, especially considering the strong pluralism of views and the delicate moral implications that characterize this question.

\footnotetext{
${ }^{291}$ UN Educational, Scientific and Cultural Organisation (UNESCO), Universal Declaration on the Human Genome and Human Rights, cited above n. 262, Article 12.

${ }^{292}$ In this regard, it is interesting to read SCHROEDER, D., "Benefit sharing: it's time for a definition”, Journal of Medical Ethics, n 33(4), (April 2007), pp. 205-209.

293 UN Educational, Scientific and Cultural Organisation (UNESCO), International Declaration on Human Genetic Data, 16 October 2003, available at http://portal.unesco.org/en/ev.php-URL ID=17720\&URL_DO=DO_TOPIC\&URL_SECTION=201.html last accessed 15 July 2018.
} 
This is why the results achieved by the two major regional human rights Court taken into consideration are praiseworthy. Of course, the threshold and the content of the protection ensured are not the same, as their reference operational frameworks are different as to the legal bases contemplated and as to the approach that the two bodies have developed also in line with their relationship with States Parties and domestic landscapes.

In this respect, the reading of States' obligations related to reproductive rights in the Inter-American system is outstanding and it is of basic importance when we consider the current process of "rejuvenation" that Latin America is currently facing in the field of abortion rights and that sometimes is not generally welcomed. It is particularly important especially when one considers that often politics and conservative faith-based activism try to curb the affirmation of reproductive rights in the region, and Brazil offers a paradigmatic example in this regard. The relevance of the results achieved by the IACtHR and of the solutions it may adopt in perspective can have a noteworthy impact at the national level. In this respect, domestic obligation deriving from the ACHR would imply a commitment to make reproductive scientific progress accessible, underpinned by the duty of non-regression in its implementation and its funding according to Article 26 of the ACHR. The impact would be particularly interesting in those domestic legal orders that provide the "bloque de constitucionalidad": in fact, the consequence would be a the "constitutionalisation" of the duties set by the conventional system in the reproductive field, also in light of the interpretation given by the Court.

The promotion of common and advanced standards of protection of reproductive rights is likely to be constantly enhanced before the IACtHR, also thanks to the nature of the conception of the rights to life adopted, capable of suiting the different exigencies that specific circumstances can pose on a case by case basis. This task seems harder for the Strasbourg Court, which has to tackle a peculiar unprecedented States' reluctancy to implement its decisions, besides the delicate pluralism of views. Any "step backward" should be hopefully avoided, through enhancement of the promising results so far achieved. In this regard, despite some self-restraint is unavoidable, the Court can rely on its capacity to interpret the ECHR as a living instrument that has characterized its case law including in the field of biolaw.

The promotion of common or at least closer standards of protection is a basic goal which also implies considerations of social justice. It goes without saying that "reproductive tourism" is capable of exacerbating social and economic gaps and it can preclude access to reproductive opportunities to less wealthy couples. This is clearly at odds with States' obligation to ensure access to health care, including reproductive services, without any discrimination in both human rights frameworks considered, according to the resources available. 
This is particularly relevant from a budgetary perspective, since ensuring full and indiscriminate access to reproductive services is an ambitious and expensive objective, even more when considered in relation to perspective opportunities related to such advanced biotechnologies as genome editing. However, it is a fundamental aim as well, if we really want to prevent law to lag behind science and to be unprepared in front of the challenges posed by scientific progress. In particular, human rights protection is not imaginable without appropriate framing, timely devised. 


\section{References:}

Aguirre Román, J., "Análisis de la sentencia C-355 de 2006 de la Corte Constitucional sobre la liberalización del aborto en Colombia: argumentos iusfilosóficos que sustentan el debate en el marco de la perspectiva de Habermas sobre el rol de la religión en la esfera pública. Estudios SocioJurídicos", Estudios Socio-Jurídicos, [S.1.], 17(2) (2015), pp. 167-198.

Andorno, R., "Biomedicine and international human rights law: in search of a global consensus", Bulletin of the World Health Organization, $\mathrm{n}^{\circ} 80$, 2002, pp. 959-963.

Andorno, R., La distinction juridique entre les personnes et les choses à l'épreuve des procréations artificielles, Paris, L.G.D.J., Bibliothèque de droit privé, 1996.

Andorno, R., La bioética y la dignidad de la persona, Madrid, Editorial Tecnos - Grupo Anaya, 2012.

Arango Olaya, M., "Inter American Court of Human Rights provisional measures adopted in B. v. El Salvador case and the strengthening of reproduction rights in the inter-American system", Anuario de Derechos Humanos, $\mathrm{n}^{\circ}$ 10, (2014), pp. 177-185.

Arévalo Narváez, C. E., Patarroyo Ramirez, P. A., "Treaties over Time and Human Rights: A Case Law Analysis of the Inter-American Court of Human Rights", Anuario Colombiano de Derecho Internacional (ACDI), $\mathrm{n}^{\circ} 10$, (2017), pp. 295-331.

Barbarosa Delgado, F. R., "El margen nacional de apreciación en el Derecho Internacional de los

Derechos Humanos: entre el Estado de Derecho y la sociedad democrática", México, Universidad Nacional Autónoma de México. Instituto de Investigaciones Jurídicas, (2012), pp. 51-82, available at http:// bibliohistorico.juridicas.unam.mx/libros/7/3160/7.pdf.

Casonato, C., "21st Century Biolaw”, Biolaw Journal - Rivista di Biodiritto, $\mathrm{n}^{\circ} 1,(2017)$.

Casonato, C., "La scienza come parametro interposto di costituzionalità", Rivista dell'Associazione Italiana dei Costituzionalisti, $\mathrm{n}^{\circ} 2$ 2, (2016).

Cassetti, L., "La "Costruzione" dei Diritti Sociali nell'approccio della Corte Interamericana e della.

Corte Europea di Strasburgo: Contenuto, Limiti e Prospettive della "Comunicazione" Giurisprudenziale", Federalismi.it - Focus Human Rights, n. 2, 2014, pp. 1-23. 
Chia, E. A., Contreras, P., “Análisis de la Sentencia Artavia Murillo y Otros ("Fecundación In Vitro") vs. Costa Rica de la Corte Interamericana de Derechos Humanos", Estudios Constitucionales, vol. 12, n 1, (2014), pp. 567-585.

Cippitani, R., "The "curious case" of Italian Law no. 40 of 2004: how the dialogue between judges is modifying legislation on medically-assisted reproduction", Rights and Science: $R \& S$, Vol. 0, (2017).

Corti, J., "El principio de precaución el la jurisprudencia internacional", Revista Epañola de Derecho Internacional, $\mathrm{n}^{\circ}$ 69(1) (2017), pp. 219-243.

Crosby, J. B., "The personhood of the human embryo", The Journal of Medicine and Philosophy, $\mathrm{n}^{\circ}$ 18(4), (1993), pp. 399-417.

Di Stefano, A., "Bio-ethics under Human Rights Scrutiny: Toward a Right to Pre-implantation Genetic Testing under the ECHR?", Strasbourg Observers, 20 September 2012, available at https://strasbourgobservers. $\mathrm{com} /$ category/cases/costa-and-pavan-v-italy/.

Di Stefano, "Tutela del corpo femminile e diritti riproduttivi: biopotere e biodiritto nella vicenda italiana in tema di diagnosi preimpianto", Osservatorio di Diritti Umani, La Comunità Internazionale, Fascicolo ${ }^{\circ}$ 4, (2013), pp. 745-772.

Díaz, Á. P., "Estatus del no nacido en la Convención Americana: un ejercicio de interpretación", Revista Ius et Praxis, n 1, Año 18, (2012).

Evans, D., Pickering, N., Conceiving the Embryo: Ethics, Law, and Practice in Human Embryology, The Hague, London, Boston, Martinus Nijhoff Publishers, 1996.

Feria Tinta, M., The Landmark Rulings of the Inter-American Court of Human Rights on the Rights of the Child. Protecting the Most Vulnerable at the Edge, Leiden, Boston, Martinus Nijhoff Publishers, 2008.

García San José, D. I., "Derecho de la Unión, Investigación embrionaria humana y patentes biológicas", Revista de Derecho Comunitario Europeo, Madrid, $n^{\circ} 41$, enero/abril, 2012, pp. 161-180.

García San José, D. I., European Normative Framework for Biomedical Research in Human Embryos, Cizur Menor, Aranzadi, 2013.

García San José, D.I., International Bio Law. An International Overview of Developments in Human Embryo Research and Experimentation, Murcia, Ediciones Laborum, 2010. 
Gomes De Andrade, N. N., "Human Genetic Manipulation and the Right to Identity: the Contradictions of Human Rights Law in Regulating the Human Genome", SCRIPTed, Volume 7, Issue 3, December 2010, pp. 429-452.

Groppi, T., Lecis Cocco-Ortu, A. M., "Le citazioni reciproche tra la Corte Europea e la Corte Interamericana dei Diritti dell'Uomo: dall'influenza al dialogo", Federalismi.it, n. 19, (2013), pp. 1-38.

Habermas, J., Il futuro della natura umana. I rischi di una genetica liberale, Torino, Einaudi, 2002.

Harris, J., Enhancing evolution. The ethical case for making better people, Princeton, Princeton University Press, 2007.

Hartman, F., "Conciliation entre l'interruption volontaires de grossese et le respect de la vie et de la dignité humaine", Le droit des personnes et de la famille à l'épreuve des droits fondamentaux présenté par l'IEJ de Paris 1 (Université Paris 1 Panthéon-Sorbonne, 20 July 2016) available at $<$ https://iej.univ-paris1.fr/openaccess/libertes-famille/lecon1/sect1/i/aivg-respect-vie-dignite/>.

Jonas, H., The Imperative of Responsibility - In Search of an Ethics for the Technological Age, Chicago, London, The University of Chicago Press, 1984.

Joseph, R., Human Rights and the Unborn Child, Leiden, Boston, Martinus Nijhoff Publisher, 2009.

Lawson, R., "The Irish abortion cases: European limits to national sovereignty?", European Journal of Health Law, $\mathrm{n}^{\circ}$ 1, (1994), pp. 167-186.

Lemaitre, J., Sider, R., "The Moderating Influence of International Courts on Social Movements: Evidence from the IVF Case Against Costa Rica", Health and Human Rights Journal, (6 June 2017), available at https://www. hhrjournal.org/2017/06/the-moderating-influence-of-international-courtson-social-movements-evidence-from-the-ivf-case-against-costa-rica/.

Letsas, G., "The ECHR as a living instrument: Its meaning and legitimacy", in Constituting Europe: The European Court of Human Rights in a National, European and Global Context, Føllesdal, A., Peters, B., Ulfstein, G., Cambridge, New York, Melbourne, Madrid, Cape Town, Singapore, São Paulo, Delhi, Mexico City, Cambridge University Press, 2010, pp. 106141. 
Madrazo, A., Vela, E., “The Mexican Supreme Court's (Sexual) Revolution?”, Texas Law Review, n 89, (2011), pp. 1863-1893.

Mancisidor, M., "Historia del Derecho Humano a la Ciencia”, in Die Subversive Kraft der Menchenrechte, Huhle, N., Huhle, T., (eds.), Oldenburg, Paulo Freire Verlag, 2015.

Mancisidor, M., "Is There Such a Thing as a Human Right to Science in International Law? “, ESIL Reflections, n 4(1), (7 April 2015), available at http://www.esil-sedi.eu/node/896.

Meza-Lopehandía G., M., "El aborto en el derecho internacional de los derechos humanos", Biblioteca Nacional del Congreso Nacional del Chile, Departamento de Estudios, Estensión y Publicaciones, 7 de noviembre de 2016.

Ollero, A., "El estatuto jurídico del embrión humano", in Ballesteros Llompart, J., Fernández Ruiz-

Gálvez, E., (eds.), Biotecnología y posthumanismo, Burgos, Thomson ReutersAranzadi, 2007, pp. 331-381.

Oberman, M., Her Body, Our Laws: On the Front Lines of the Abortion War, from El Salvador to Oklahoma, Boston, Beacon Press, 2018.

Pasqualucci, J. M., The Practice and Procedure of the Inter-American Court of Human Rights, Cambridge, New York, Melbourne, Madrid, Cape Town, Cambridge University Press, 2013.

Paulk, L. B., "Embryonic Personhood: Implications for Assisted Reproductive Technology in International Human Rights Law", American University Journal of Gender Social Policy and Law, n 22(4), 2014, pp. 781-823.

Penasa, S., "The Italian Law on assisted reproductive technologies N. 40 of 2004, facing the European Court of Human Rights: the case of Costa and Pavan v. Italy", Revista de Derecho y Genoma Humano/Law and the Human Genome Review, n³7, (2012), pp. 155-178.

Poli, L., "Bioethics, human rights and their interplay in the legal reasoning of ECtHR's case law on artificial reproductive technologies", Federalismi.it, Focus on Human Rights, $n^{\circ}$, (2017).

Poli, L., "La sentenza Parrillo c. Italia e quello che la Corte (non) dice sullo status dell'embrione", Quaderni di SIDIblog, (2015), pp. 511-516.

Rachovitsa, A., "Treaty Clauses and Fragmentation of International Law: Applying the More Favourable Protection Clause in Human Rights Treaties", Human Rights Law Review, n. 16 (1), (1 March 2016). 
Rodotà, S., Il diritto di avere diritti, Editori Laterza, Roma-Bari, 2012.

Rodotà, S., Trattato di Biodiritto, ll Governo del Corpo, Milano, Giuffré Editore, 2011.

Romeo Casabona, C. M., "El estatuto jurídico del embrión humano", Revista de Humanidades Médicas, $\mathrm{n}^{\circ}$ 8(4), (2007), pp. 111-124.

Ruiz de la Cuesta, A., "El debate doctrinal sobre el principio de la protección de la vida humana. Una lectura crítica desde la concepción gradualista o progresiva", in García San José, D. I., (ed.), Marco Jurídico Europeo relativo a la Investigación Biomédica en Transferencia Nuclear y Reprogramación Celular, Sevilla, Thomson Reuters-Aranzadi 2012.

Ruiz Miguel, A., Derecho a la Vida y Constitución: Consecuencias de la Sentencia de la Corte Interamericana de Derechos Humanos "Artavia Murillo v. Costa Rica"”, Estudios Constitucionales, Año 12, n 1, (2014), pp. 71-104.

Stopler, G., "Reproductive rights", Max Planck Encyclopedia of Comparative Constitutional Law [MPECCoL], 2017.

Valerio, C., Vargas, K., Raventós, H., "IVF in Costa Rica", JBRA Assisted Reproduction, $\mathrm{n}^{\circ}$ 21(4), (2017), pp. 366-369.

Vicente Giménez, T., Marzocco, V., Pozzolo, S., Farano, A., "La Subjetividad Político-Jurídica de Las Mujeres y La Biotecnología Como Política De Reproducción”, Revista Bioderecho.es - Revista Internacional de Investigación en Bioderecho, $\mathrm{n}^{\circ}$. 3, (2016), available at http://revistas. um.es/ bioderecho/article/view/260301.

Von Bogdandy, A., Ferrer Mac-Gregor, E., Morales Antoniazzi, M., Piovesan, F., Transformative Constitutionalism in Latin America: The Emergence of a New Ius Commune, Oxford, New York, Oxford University Press, 2017. Zegers-Hochschild, F., Enrique Schwarze, J., Crosby, J. A., Musri, C., Urbina, R. T., "Assisted reproductive techniques in Latin America: The Latin American Registry, 2014”, JBRA Assisted Reproduction, No. 21(3), (2017), pp. 164-175. 